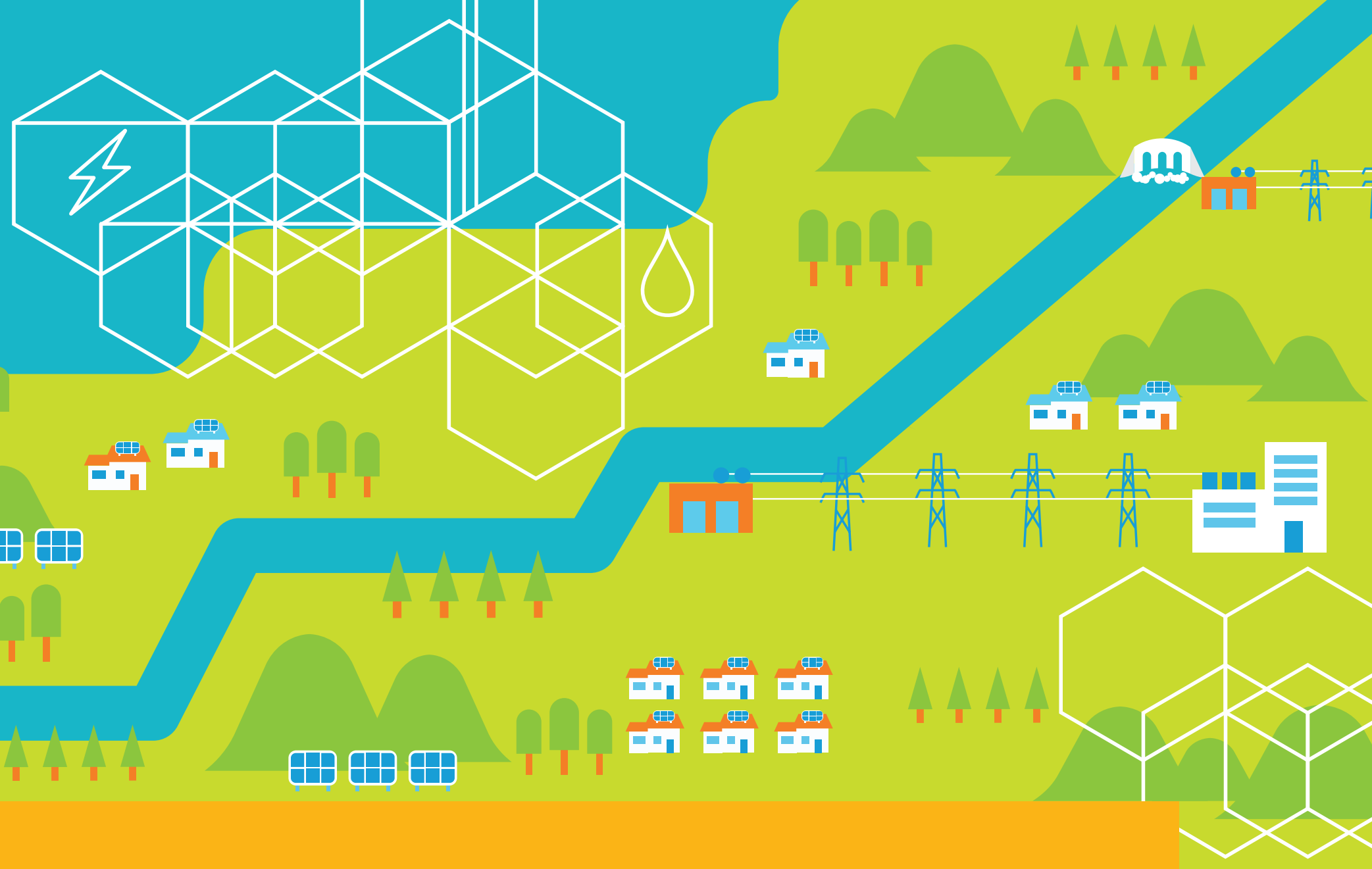

MANAGING NEPAL'S DUDH KOSHI

RIVER SYSTEM FOR A FAIR AND SUSTAINABLE FUTURE

SEPTEMBER 2019 



\section{MANAGING NEPAL'S DUDH KOSHI RIVER SYSTEM FOR A FAIR AND SUSTAINABLE FUTURE}

SEPTEMBER 2019 
(C) 2019 Asian Development Bank

6 ADB Avenue, Mandaluyong City, 1550 Metro Manila, Philippines

Tel +632632 4444; Fax+6326362444

www.adb.org

Some rights reserved. Published in 2019.

ISBN 978-92-9261-550-5 (print), 978-92-9261-551-2 (electronic)

Publication Stock No. TCS190053

DOI: http://dx.doi.org/10.22617/TCS190053

The views expressed in this publication are those of the authors and do not necessarily reflect the views and policies of the Asian Development Bank (ADB) or its Board of Governors or the governments they represent.

ADB does not guarantee the accuracy of the data included in this publication and accepts no responsibility for any consequence of their use. The mention of specific companies or products of manufacturers does not imply that they are endorsed or recommended by ADB in preference to others of a similar nature that are not mentioned.

By making any designation of or reference to a particular territory or geographic area, or by using the term "country" in this document, $\mathrm{ADB}$ does not intend to make any judgments as to the legal or other status of any territory or area.

This work is available under the Creative Commons Attribution 3.0 IGO license (CC BY 3.0 IGO)

https://creativecommons.org/licenses/by/3.0/igo/. By using the content of this publication, you agree to be bound by the terms of this license. For attribution, translations, adaptations, and permissions, please read the provisions and terms of use at https://www.adb.org/terms-use\#openaccess.

This CC license does not apply to non-ADB copyright materials in this publication. If the material is attributed to another source, please contact the copyright owner or publisher of that source for permission to reproduce it. ADB cannot be held liable for any claims that arise as a result of your use of the material.

Please contact pubsmarketing@adb.org if you have questions or comments with respect to content, or if you wish to obtain copyright permission for your intended use that does not fall within these terms, or for permission to use the ADB logo.

Corrigenda to ADB publications may be found at http://www.adb.org/publications/corrigenda.

Notes:

In this publication, “\$” refers to United States dollars.

All photos by Adrian Young.

Cover design by Rocilyn Locsin Laccay. 


\section{Contents}

Tables and Figures

Acknowledgments

Abbreviations

vii

Weights and Measures

vii

Executive Summary

viii

CHAPTER 1: Introduction

1.1 Background

1.2 Profile of the Koshi Basin

1.3 Hazards

1.4 Socioeconomic Background

1.5 Environment

CHAPTER 2: Hydrology and Water Resources 9

2.1 The Hydrometric Network 9

2.2 Approach of the Dudh Koshi River System Study 10 to Water Resources Assessment

2.3 Soil Water Assessment Tool Model Calibration 12

CHAPTER 3: Hydropower Development $\quad 14$

$\begin{array}{lll}3.1 & \text { Overview } & 14\end{array}$

3.2 Hydropower Planning for the Koshi River Basin 15

$\begin{array}{ll}\text { CHAPTER 4: Irrigation } & 18\end{array}$

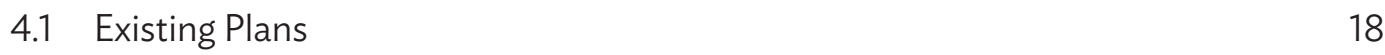

4.2 Irrigation Development 18

$\begin{array}{lll}4.3 & \text { Agriculture } & 21\end{array}$

CHAPTER 5: Environmental and Social Impacts 22

$\begin{array}{lll}5.1 & \text { Fisheries } & 22\end{array}$

5.2 Social and Cultural Impacts 24 
CHAPTER 6: Strategies for Integrated Development of the Dudh Koshi Sub-Basin 27

6.1 Benefit Sharing 27

6.2 Development Priorities of Dudh Koshi Stakeholders 29

6.3 Catchment and Hazard Management 30

6.4 Roads 32

6.5 Agriculture and Hill Irrigation 33

6.6 Water Supply and Sanitation 34

$\begin{array}{lll}6.7 & \text { Fisheries } & 34\end{array}$

6.8 Rural Electrification and Micro Hydropower 34

$\begin{array}{ll}6.9 \text { Microenterprises and Tourism } & 35\end{array}$

CHAPTER 7: Legal and Institutional Framework 37

$\begin{array}{lll}7.1 & \text { Requirements } & 37\end{array}$

$\begin{array}{ll}7.2 & \text { Legal and Institutional Framework } \\ 7.3 & \text { Planning Frameworks }\end{array}$

$\begin{array}{ll}7.3 & \text { Planning Frameworks } \\ 7.4 & \text { The Way Forward }\end{array}$

$\begin{array}{ll}7.4 & \text { The Way Forward } \\ \end{array}$

CHAPTER 8: Analysis of Hydropower Development Scenarios 42

8.1 Evaluation of Development Scenarios $\quad 42$

8.2 Scenario Evaluation Results 43

CHAPTER 9: Conclusions and Recommendations 52

9.1 Introduction 52

9.2 Hydropower Planning in the Sun and Dudh Koshi River Systems 52

9.3 Planning for Irrigation Diversions from the Koshi River 54

9.4 Management of Fisheries and Aquatic Environment 55

9.5 Integrated Approach for the Dudh Koshi 57

9.6 Institutional Framework 58

9.7 Follow-Up Studies $\quad 61$

9.8 Integrated Investment in the Dudh Koshi Sub-Basin 61

$\begin{array}{ll}\text { References } & 66\end{array}$ 


\section{Tables and Figures}

\section{Tables}

1 Population of Three Districts in the Dudh Koshi Sub-Basin 7

2 Estimate of Resettlement Requirements for Key Hydroelectric Power Projects 25

3 Stakeholders' Ranking of Development Priorities 29

4 Hydropower Production with Full Development 45

5 Comparison of Scenario Energy Production and Index Costs 47

6 Irrigation Diversions 54

7 Integrated Investment Strategy for the Dudh Koshi Sub-Basin 64

\section{Figures}

1 Dudh Koshi Sub-Basin 2

2 The Koshi River Basin 4

3 Tributaries' Contributions to Sapta Koshi Annual Flow 5

4 Dudh Koshi Basin Population Density 8

5 Stream Gauging Stations in the Koshi River Basin 10

6 Simplified Water Evaluation and Planning Model Schematic 12

7 Calibration Results for Station 695 Sapta Koshi at Chatara 13

8 Proposed Developments of Relevance to the Dudh Koshi Dam Options 16

9 The Reservoir Cascade Proposed by the Koshi River Master Plan Study, $1985 \quad 16$

10 Potential Irrigation Area 19

11 Erosion and Priority Conservation Areas for the Dudh Koshi River System 31

12 Flow Impact of Diversions Upstream of the Sapta Koshi High Dam 44

13 Simulated Mean Mid-March Flow Balances 49

14 Simulated Mid-March Flow Balances 1:5 Drought 50

15 Simulated Flow Balances with the Dudh Koshi Storage Hydroelectric Project 51 Tunnel Option

16 Proposed Dudh Koshi Integrated Development Program 65 


\section{Acknowledgments}

The Nepal Electricity Authority, the Department of Electricity Development, and the Department of Irrigation provided the background information about the potential development of the Dudh Koshi sub-basin and the Koshi Basin. Vidhisha Samarasekara, senior climate change specialist, and Arnaud Cauchois, principal water resources specialist, South Asia Environment and Natural Resources Division, led the project team from the Asian Development Bank (ADB) with Adrian Young, consultant and team leader, Integrated Water Resources Management; Robin Wardlaw, consultant and hydrologist, Water Resources; and Miroslav Marence, consultant and hydropower planner.

This report incorporates the data and research findings of the International Centre for Integrated Mountain Development (ICIMOD) and the International Water Management Institute (IWMI) under the Koshi Basin Programme, which is supported by the Government of Australia through the Sustainable Development Investment Portfolio for South Asia. Hydrological and water resources planning models set up by the IWMI have been adapted for this report.

The ADB project team is grateful for the support of the Nepal Electricity Authority staff in the study. The assistance of the ICIMOD and the IWMI is greatly appreciated. 


\section{Abbreviations}

$\begin{array}{ll}\text { ADB } & \text { Asian Development Bank } \\ \text { DDC } & \text { district development committee } \\ \text { DKRS } & \text { Dudh Koshi River System } \\ \text { DKSHEP } & \text { Dudh Koshi Storage Hydroelectric Project } \\ \text { IBIP } & \text { Integrated Basin Investment Program } \\ \text { ICIMOD } & \text { International Centre for Integrated Mountain Development } \\ \text { IWMI } & \text { International Water Management Institute } \\ \text { IWRM } & \text { integrated water resources management } \\ \text { JICA } & \text { Japanese International Cooperation Agency } \\ \text { KRB } & \text { Koshi River Basin } \\ \text { KRMPS } & \text { Koshi River master plan study } \\ \text { NEA } & \text { Nepal Electricity Authority } \\ \text { PRC } & \text { People's Republic of China } \\ \text { RBA } & \text { River Basin Authority } \\ \text { RBO } & \text { river basin organization } \\ \text { RoR } & \text { run-of-river } \\ \text { SWAT } & \text { soil water assessment tool } \\ \text { WEAP } & \text { water evaluation and planning } \\ \text { WEC } & \text { Water and Energy Commission }\end{array}$

\section{Weights and Measures}

$\begin{array}{ll}\text { ha } & \text { hectare } \\ \mathrm{km}^{2} & \text { square kilometer } \\ \mathrm{mm} & \text { millimeter } \\ \mathrm{m} & \text { meter } \\ \mathrm{m}^{3} / \mathrm{s} & \text { cubic } \text { meter per second } \\ \mathrm{MW} & \text { megawatt }\end{array}$




\section{Executive Summary}

This publication sets out the findings and recommendations of a study of the Dudh Koshi River System (DKRS) in Nepal. The study reveals opportunities for developing equitable and efficient water resources management that is economically and environmentally sustainable and considers the challenges of climate change. The study has developed a strategic and holistic planning framework that covers the technical, economic, social, and environmental aspects of integrated water resources management and development of the DKRS.

The study contributes to strategic planning from a basin-wide perspective by supporting the design of the Dudh Koshi Storage Hydroelectric Project (DKSHEP). It includes analyses of the following issues: water resources, hydropower and irrigation development, the social and environmental impacts of hydropower development, and opportunities for integrated basin development.

\section{A. Water Resources}

The project team from the Asian Development Bank (ADB) conducted water resources analyses in collaboration with the International Water Management Institute (IWMI) and the International Centre for Integrated Mountain Development (ICIMOD), who shared hydrological and water resources planning models and climate change scenarios developed under the Koshi Basin Programme. Under the DKRS study, the hydrological and water resources planning models were refined.

The DKRS is one of the main tributaries of the Koshi River Basin. While the study focuses on the DKRS, it also incorporates a hydrological analysis of the larger Koshi River Basin (which includes the catchments upstream of Chatara in the People's Republic of China) and a detailed assessment of hydropower and irrigation development scenarios in the Sun and the Dudh Koshi River Systems.

In Nepal's part of the Koshi River Basin, annual rainfall typically ranges from 1,500 millimeters $(\mathrm{mm}$ ) to $2,500 \mathrm{~mm}$, while in the north of the Greater Himalayas in the Tibet Autonomous Region, annual rainfall is typically about $300 \mathrm{~mm}$. About $80 \%$ of the annual rainfall occurs from June to September throughout the basin. Because of the mountainous terrain, the density of the rain gauge and meteorological station networks is low.

The Koshi River Basin's natural environment is fragile, and the rivers carry large sediment loads during the wet season. Feasibility studies for the DKSHEP in 1998 adopted a sediment 
yield of 5,700 tonnes per square kilometer $\left(\mathrm{km}^{2}\right)$ per year. The ICIMOD recently studied soil erosion dynamics in the basin using a geographic information system and remote-sensing techniques. The analysis of ICIMOD data indicates that about $18 \%$ of the catchment area produces almost $75 \%$ of the annual sediment erosion. If erosion from these areas could be reduced by $50 \%$, reservoir life and the life of hydromechanical equipment could be extended by almost $40 \%$.

A number of studies have considered the possible impacts of climate change on the basin's water resources. Most of these studies indicate increased runoff in the future. The DKRS studies that $A D B$ conducted also indicate an increased river flow under all but one of the scenarios considered.

\section{B. Hydropower and Irrigation Development}

Currently, there has been no significant water resources development in the Koshi River Basin upstream of Chatara, although there has been a small-scale run-of-river hydropower development. The master plan study for Koshi River water resources development, completed in 1985, recommends cascading large-scale hydropower dams in the Sun and Dudh Koshi river systems.

Hydropower studies under the DKSHEP focus on planning for hydropower in the Sun and Dudh Koshi river systems. The studies include an assessment of seven major hydropower projects that affect or are affected by the DKSHEP: Dudh Koshi; Sun Koshi 1, 2, and 3; Sun Koshi Marin Diversion; Kamala Diversion; and Sapta Koshi High Dam (including the Chatara barrage). The Sun Koshi Marin, the Kamala diversions, and the Chatara barrage involve irrigation developments.

This study reviews and compiles the findings of the 1985 Koshi River master plan study and more recent studies by the Nepal Electricity Authority (NEA) and the Department of Irrigation. This study also gives an updated technical assessment of the various proposed hydropower schemes.

The study analyzes the hydropower performance of each scheme, assessing the different scheme combinations on water, power, energy, and indicative costs. The analysis points out the need to investigate appropriate levels of environmental flow, which could affect the schemes' operational parameters.

\section{Social and Environmental Impacts}

The environmental impacts of hydropower development in the basin will be significant, and will include major changes to the river flow and morphology, which will affect fisheries and aquatic biodiversity. The standards for environmental flow are not well-defined, and appropriate emphasis must be given to aquatic habitat surveys and assessments. The default criteria for hydrological environmental flow are significantly lower than international practices, and could dry some of the finest rivers. 
Communities were interviewed about their perceptions on the hydropower programs. In general, responses to the proposed hydropower development were positive, especially in regard to job opportunities and improved roads to markets and their homes. In the Solukhumbu District where hydropower development is ongoing, there has been no clear mechanism to address stakeholder expectations and complaints, and no effective liaison with the developers.

\section{Opportunities for Integrated Basin Development}

Integrated basin development incorporating the needs of the communities and the environment is in line with the government policy. If the hydropower development is planned, coordinated, and managed effectively, then the hydropower investor, communities, and the environment will all benefit.

The study examines the possible strategies to share benefits with and involve communities. Extensive interviews were conducted with local stakeholder family groups to assess their perception of hydropower projects and obtain their perspective on long-term development priorities and issues.

\section{E. Conclusions and Recommendations}

The DKSHEP cannot be planned without integrating development and environmental parameters. The study's core findings are summarized below.

(i) The hydropower planning analysis focuses on five hydropower storage projects and three multipurpose irrigation and hydropower diversion projects in the Sun Koshi sub-basin, which would be affected by the development of the DKSHEP. All of these eight projects are being considered as potential investments by the Government of Nepal. Selected scenarios were reviewed based on the current project plans to assess the implications in terms of water resources and potential energy outputs.

(ii) The three planned multipurpose Koshi diversion projects (Marin, Kamala, and Chatara) will have significant hydrological and environmental impacts; estimates have been made of the existing and potential irrigation areas, and supplies including a mix of surface and groundwater.

(iii) There is a need to better define the irrigation diversions as part of the overall planning for the Sun and Dudh Koshi rivers. There is significant potential to reduce the diversion requirements through improved irrigation management, irrigation efficiency, and conjunctive use of surface and groundwater. The viability and economic feasibility of large-scale new canalization and the requirement to upgrade agricultural productivity also need to be assessed. Provision of storage can help meet the irrigation demands and avoid adverse impacts on low flows in the downstream river systems. 
Follow-up studies. The development of water resources in the Sun and Dudh Koshi river systems requires further studies to assess and identify the optimum combination of different project development scenarios in terms of their technical, social, and economic viabilities. These studies should complement and run in parallel with the DKSHEP feasibility studies and design.

Fisheries and aquatic environment management. Hydropower development in the DKRS will have major effects on fish and the aquatic environment. Fisheries and aquatic management measures need to be assessed and implemented in relation to the wider Koshi Basin and not just the Dudh Koshi. New approaches to environmental flows are required toward better aquatic biodiversity.

Integrated Basin Investment Program. Hydropower projects should be integrated with parallel programs to support sustainable socioeconomic development in the communities and management of the catchments and the environment. A preliminary proposal for an Integrated Basin Investment Program (IBIP) for the Dudh Koshi sub-basin has been prepared. It is proposed that the program be implemented over 7 years in parallel with the construction of the DKSHEP and other run-of-river schemes in the basin. The program would include catchment management; roads; agriculture; fisheries and aquatic management; rural electrification; community initiatives; and infrastructure including education, health, water supplies, small enterprises, and tourism. The program cost would be financed through (i) the hydropower developers who would directly benefit from road improvements, reduced levels of sediment through catchment management as well as requirements for social and environmental mitigation and (ii) royalty payments in the form of an upfront loan repayable from future royalties and government contribution.

Institutional framework. To integrate the approaches for water resources management and development, the institutional framework needs to be strengthened by establishing the following: (i) a Koshi-empowered committee to support the short- and medium-term planning and decision making on hydropower and irrigation diversion; and (ii) a corporate Koshi River Basin Authority (KRBA), which would be a state-owned company with the mandate for integrated management of the KRB. Hydropower royalty payments and irrigation service fees would cover the KRBA costs. The KRBA would report to a Koshi River Basin council whose members would be selected from different levels of government and would include a high level of representation from stakeholders and civil society. 



\section{CHAPTER Introduction}

\subsection{Background}

This publication reports on a study of the Dudh Koshi River System (DKRS) that aimed to develop integrated approaches to planning and developing hydropower and river diversion projects. ${ }^{1}$ The field work was implemented over 12 months and completed in October 2016. It formed part of the knowledge and institutional support for the Water Financing Program of the Asian Development Bank (ADB) and the knowledge partnership between ADB and the UNESCO-IHE Institute for Water Education (now the IHE Delft Institute for Water Education).

The Koshi River Basin (KRB) in Nepal holds substantial water resources that have yet to be developed, despite a number of master plans and feasibility studies that were initiated in the 1980s. Development follows a project-based approach, which does not factor in other planned or proposed developments. It is now increasingly evident that more holistic strategies are needed-those that seek to incorporate river basin planning and integrate potential social, environmental, and climate change issues across multiple projects (e.g., hydro, irrigation, flood control) over the entire basin and sub-basins. Development of high-altitude hydro schemes needs to be planned carefully to address the vulnerabilities and high sensitivities of the catchments and communities.

Development actors' knowledge gaps on water resources, including the impacts of climate change; conjunctive use of integrated water systems; and catchment management to ensure sustainability of soil and water and reduced risk from extreme climate events.

The DKRS study aims to identify key issues and requirements to achieve economically and environmentally sustainable development, and help address the impacts of climate change. The study focuses on the Dudh Koshi sub-basin, one of the main tributaries of the Koshi River System (Figure 1).

As there are significant linkages and impacts of developments on the river system upstream and downstream, the study has also incorporated a hydrological analysis of the wider Koshi River System, including the upstream catchment in the People's Republic of China (PRC), and an assessment of hydropower and irrigation development scenarios in the Sun and Dudh Koshi river systems. 
The output of the DKRS study is presented as a strategic planning framework for the Koshi Basin and also to support the planning of the Dudh Koshi Storage Hydroelectric Project, thus contributing to strategic planning from a basin-wide perspective.

The study involves

(i) a water resources assessment based on a rainfall runoff model (soil water assessment tool [SWAT]) including climate change simulations and an analysis of water resources development scenarios through a systems planning model (water evaluation and planning [WEAP]) to explore development options and their impacts and sensitivities;

(ii) an analysis of a large-scale hydropower development focusing on seven large schemes in the Dudh Koshi, Sun Koshi, and downstream Sapta Koshi;

(iii) an analysis of irrigation development in the eastern Terai and the potential for irrigation diversion projects from the Koshi River;

(iv) a review of environmental and social impacts of large-scale hydropower development;

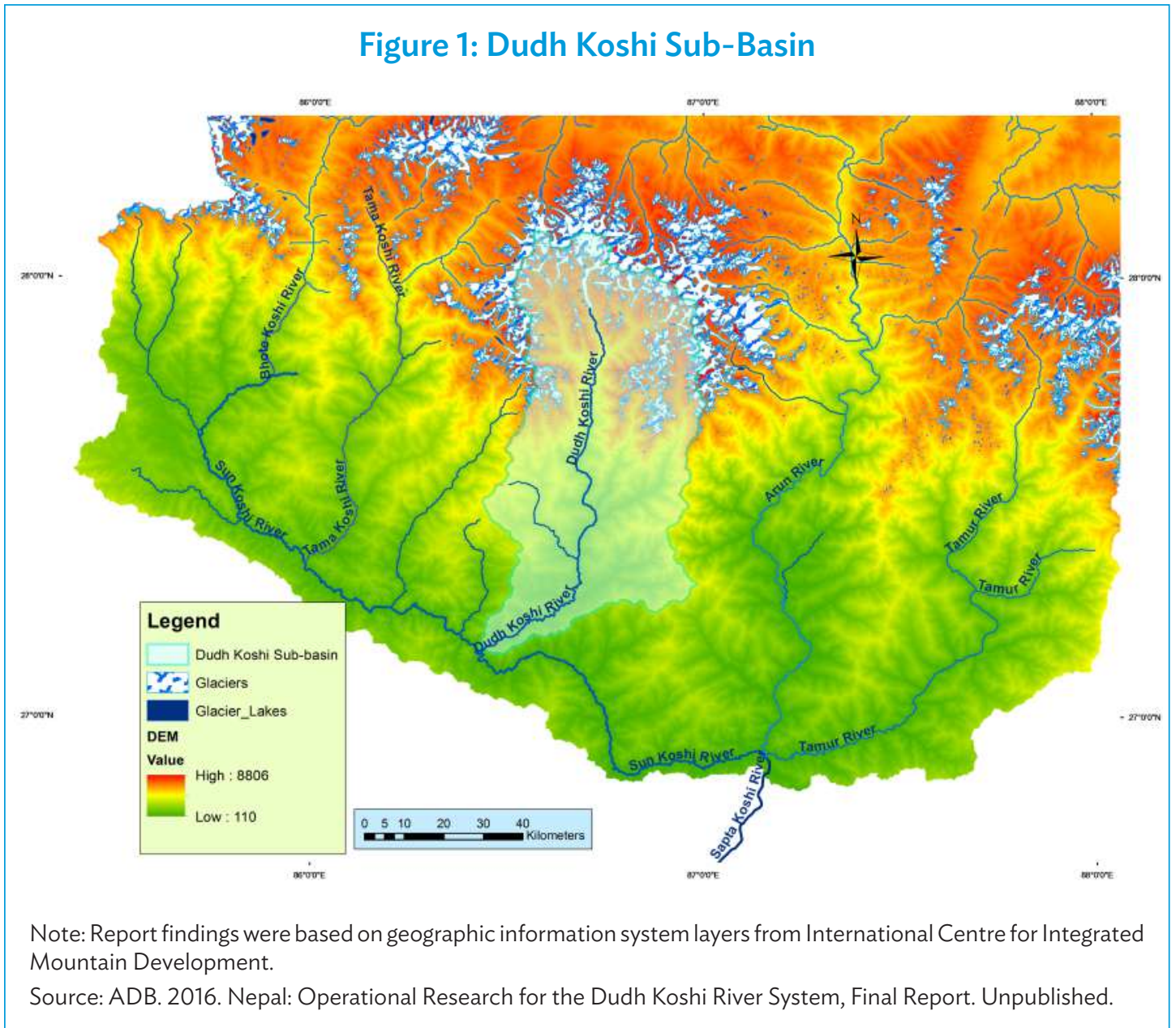


(v) a review of integrated development planning for the DKRS, incorporating extensive stakeholder interviews and consultations to assess community perceptions on the expansion of hydropower and overall development needs; and

(vi) an assessment of the legal and institutional framework including a review of institutional capacities and possible approaches for long-term sustainable and effective integrated water resources management.

\subsection{Profile of the Koshi Basin}

\section{Water Resources}

The Koshi River is the largest tributary of the Ganges. It is a transboundary river crossing the PRC, Nepal, and India. With a basin area of 87,311 square kilometers $\left(\mathrm{km}^{2}\right)$ upstream of its confluence with the Ganges, it is the largest river in Nepal. Figure 2 presents a map of the larger KRB. Dixit et al. (2009) have identified six distinct geological and climatic zones in the basin: the Tibet Autonomous Region plateau, the high Himalaya, the midland hills, the Mahabharat Lekh (range), the Chure (Siwalak range), and the Terai.

There are large temporal and spatial variations in climate across the basin, driven by topographic variations and the southwest and northeast monsoons. Most precipitation (about 80\%) occurs during the southwest monsoon from June to September. Precipitation generally decreases from south to north. The trans-mountain region north of the Himalayas is arid, being in the rain shadow of the mountains to the south.

The population of the entire KRB including the parts in India and the PRC is 39.2 million, with the highest densities in the Terai. Population growth in the last decade was 23\%, with the highest rates of growth in the downstream areas. The Nepal part of the KRB has 5.1 million (2001 census) residents in 18 districts.

The KRB has 3.4 million hectares (ha) of agricultural land, of which about $50 \%$ is irrigated. A number of large schemes exist in the Terai where most irrigation takes place. In the low hill areas, irrigated agriculture is about $4 \%$ of the total.

Fisheries in the KRB are an important source of livelihood for small traditional fishing families, who are scattered and not organized; and thus records are scanty. However, estimates reveal that fish production has not been commensurate with the potential productivity of the river systems; and, in some parts, fisheries are highly exploited (Yadav n. d.). The reasons for the pressure on fisheries are complex, and may include overfishing, use of inappropriate fishing methods, and construction of the Koshi barrage, which is a major constraint to fish migration.

While this study focuses on the Dudh Koshi sub-basin, the water resources of the KRB upstream of Chatara play a significant role in meeting the irrigation demands of the lowland Terai area through irrigation diversions to the Sunsari Morang area on the left bank downstream of Chatara, and from the Koshi Barrage further downstream. Interbasin transfers have been proposed from the Sun Koshi River south to the Bagmati River and to the Kamala River. It is therefore necessary to consider aspects of the Koshi Basin as a whole. The Koshi Basin has been considered at five different levels: (i) the Dudh Koshi river system; 


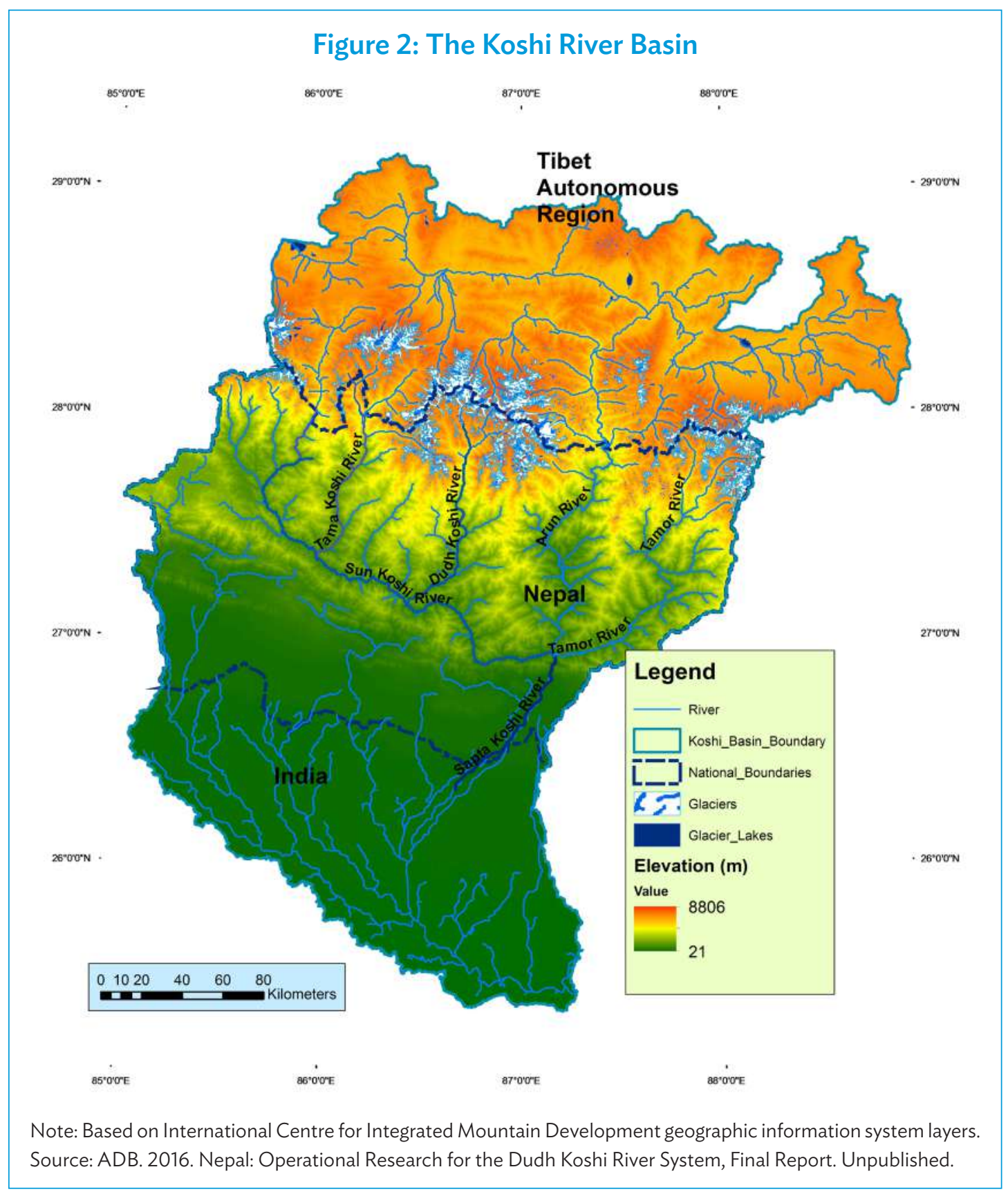

(ii) the Sun and Dudh Koshi river systems; (iii) the Nepal Koshi river systems; (iv) the larger Koshi river basin upstream of Chatera including Nepal and the PRC; and (v) the whole Koshi river basin including India, Nepal, and the PRC.

Figure 2 shows some topographic and physiographic features of the basin: the Terai plains lie in the south, bounded by the Siwalik Hills in the north, and the Mahabharat Range, which is the southern boundary of the Sun Koshi sub-basin. To the north is the area known as the Small Himalaya with elevations below 2,000 meters (m), followed by the Middle Himalaya with elevations ranging from 2,000 m to 3,000 m. Above 3,000 m is the Greater Himalaya, 
where vegetation is sparse, and peaks, including Mt. Everest at $8,848 \mathrm{~m}$, are permanently covered with snow wherein significant glaciation occurs. To the north of the Greater Himalayas lie the Tibet Autonomous Region Himalayas and the trans-mountain region between the Himalayas and the Tibet Autonomous Region Plateau.

The DKRS is one of six major tributaries that make up the larger KRB. The Indrawati, Tama Koshi, and Dudh Koshi rivers all contribute to the Sun Koshi, which combines with the Arun and Tamur rivers to form the Sapta Koshi, just upstream of the Chatara gauging station. The Sun Koshi forms the largest part of the Sapta Koshi flows (Figure 3). The Sapta Koshi flows south across the Terai, and is a major tributary of the Ganges in India.

\section{Figure 3: Tributaries' Contributions to Sapta Koshi Annual Flow}

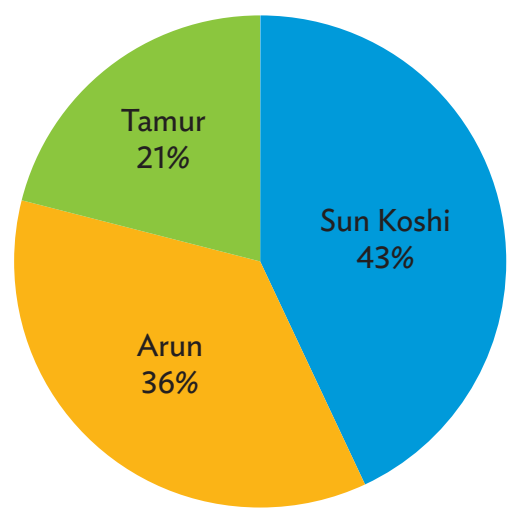

Source: ADB. 2016. Nepal: Operational Research for the Dudh Koshi River System, Final Report. Unpublished.

The area of the larger KRB upstream of Chatara totals 54,100 square kilometers $\left(\mathrm{km}^{2}\right)$. Of this, $48 \%$ lies in Nepal and 52\% in the PRC. Most of the area in the PRC contributes to the Arun River with a small part going to the Sun Koshi via the Indrawati and Tama Koshi rivers. The Dudh Koshi has a total catchment area of $3,712 \mathrm{~km}^{2}$ upstream of the gauging station at Rabuwa Bazar, and has about 22\% of the overall catchment area of the Sun Koshi.

\section{Climate}

Climatic conditions vary widely across the whole KRB, influenced mainly by the southwest monsoon that brings high rainfall to the southern parts of the basin in the summer months, and the northeast monsoon that brings drier winter conditions. The northern part of the basin in the rain shadow of the Greater Himalayas during the southwest monsoon has a cold, dry climate. Generally, Nepal has four seasons: spring or pre-monsoon from April to May, summer or monsoon from June to September, post-monsoon in October to November, and winter from December to March. In the Nepal part of the KRB, annual rainfall typically ranges from 1,500 millimeters $(\mathrm{mm}$ ) to $2,500 \mathrm{~mm}$, while to the north of the Greater Himalayas in the PRC, annual rainfall is typically $300 \mathrm{~mm}$. About $80 \%$ of the annual rainfall throughout the basin falls from June to September. Westerly intrusions in winter and in the pre-monsoon season account for most of the remaining precipitation. 


\section{Glaciers}

Approximately 1,081 glaciers with a total area of 2,814 $\mathrm{km}^{2}$ and an estimated ice reserve of 276 cubic kilometers $\left(\mathrm{km}^{3}\right)$ can be found in the entire KRB. It is also estimated that 316 glaciers occupy an area of $415 \mathrm{~km}^{2}$ and ice reserve cover $42 \mathrm{~km}^{3}$ in the DKRS. ${ }^{2}$ There has been considerable concern about the rate of retreat of Himalayan glaciers and the potential impact of this on water resources in Nepal and India. A study of the World Wildlife Fund in 2009 indicated an almost 40\% reduction in snow and ice cover in the DKRS between 1975 and 2000, an 18\% increase in debris glacier cover, and an $8 \%$ increase in the area of glacial lakes. The study did not indicate the distinction between snow and glacier cover. More recently, Racoviteanu et al. (2015) assessed the changes in glacial characteristics in the Kanchenjunga-Sikkim area, the western part of which is in Eastern Nepal draining to the Arun and Tamur rivers. They found an area loss between 1962 and 2000 of $0.53 \% \pm 0.2$ per year in the Nepal part of the study area, which is significantly lower than that reported by the World Wildlife Fund for the DKRS.

\subsection{Hazards}

The KRB catchments are inherently fragile for a mix of reasons, including the tectonic plate dynamics, weak and deformed rock, steep topography, intense seasonal precipitation, land use change, and climate change impacts. The region is exposed to multiple geomorphologic hazards such as earthquakes, landslides, floods, debris flows, soil erosion, and glacial lake outburst flood. The Water and Energy Commission Secretariat (WEC Secretariat 2011) has identified five major flood types affecting Nepal:

(i) continuous rainfall and cloudburst,

(ii) glacial lake outburst flood,

(iii) landslide dam outburst flood,

(iv) floods triggered by the failure of infrastructure, and

(v) sheet flooding or inundation of lowland areas due to an obstruction imposed against flow.

In the context of the DKRS and the larger KRB upstream of Chatara, the first three flood types are at present the most relevant. In general, the glacial lake outburst flood is considered the most serious flood hazard in Nepal (Yamada and Sharma 1993). In the larger KRB, 1,224 glacial lakes occupy an estimated area of $177 \mathrm{~km}^{2}$. A total area of $15.5 \mathrm{~km}^{2}$ are covered by 534 glacial lakes in the DKRS. ${ }^{3}$

Landslips and associated river blockages pose another hazard. Unlike the glacial lake outburst floods, wherein the scale and possible impacts of a breach are quantifiable, very

2 Data sourced from the Geographic Information System (GIS) of the International Centre for Integrated Mountain Development (ICIMOD) accessed in 2011.

3 Data based on the recent work and GIS layers of ICIMOD. 
little information is available to identify locations of potential river blockage and assess the potential scale of damage.

\subsection{Socioeconomic Background}

The Dudh Koshi sub-basin sits within the districts of Okhaldhunga, Khotang, and Solukhumbu. The 2011 census estimates that the total population for the three districts is about 460,000 (Table 1 and Figure 4).

Table 1: Population of Three Districts in the Dudh Koshi Sub-Basin

\begin{tabular}{lccccc} 
District & No. of VDCs & $\begin{array}{c}\text { No. of } \\
\text { Households }\end{array}$ & $\begin{array}{c}\text { Average } \\
\text { Pousehold } \\
\text { Size }\end{array}$ & $\begin{array}{c}\text { Male/Female } \\
\text { Ratio } \\
(\%)\end{array}$ \\
\hline Okhaldunga & 57 & 32,502 & 147,984 & 4.55 & 86 \\
Khotang & 76 & 42,664 & 206,312 & 4.84 & 89 \\
Solukhumbu & 34 & 23,785 & 105,886 & 4.45 & 94 \\
Total & 147 & 98,951 & 460,182 & 4.61 & 89 \\
\hline
\end{tabular}

VDC = village development committee.

Source: Government of Nepal, Central Bureau of Statistics. 2011 National Census.

A socioeconomic survey carried out by the DKRS study shows that communities have small landholdings and traditional farming systems. From the interviews, the average annual farm income of a sample of respondents was $\$ 374$; farmers who combined business with farming had relatively higher incomes of about $\$ 500$; farm incomes were significantly lower in Solukhumbu, which has steep terrain and higher altitudes. About 37\% of the families surveyed benefited significantly from remittances from family members working in other parts of Nepal or abroad.

\subsection{Environment}

The KRB contains highly diverse physiography, ecosystems, and habitats. In recent years, the use of land for agricultural and building purposes has been increasing and forest areas have been decreasing. Forests continue to degrade due to overgrazing and overharvesting of firewood. Unsuitable fishing methods and overfishing negatively affect the fish populations. Migration routes are currently open except for the Koshi Barrage where long-distance passage from India's major rivers is largely blocked.

Residents of the basin are already experiencing the impacts of climate change on their livelihoods, such as erratic monsoon rainfall patterns, floods, and extended drought periods. Climate change is affecting the glaciers, with rivers benefiting from increased flows from loss of glacier volume. Springs are used extensively for drinking water, but climate change impacts are affecting flows during the lean winter months. 


\section{Figure 4: Dudh Koshi Basin Population Density}

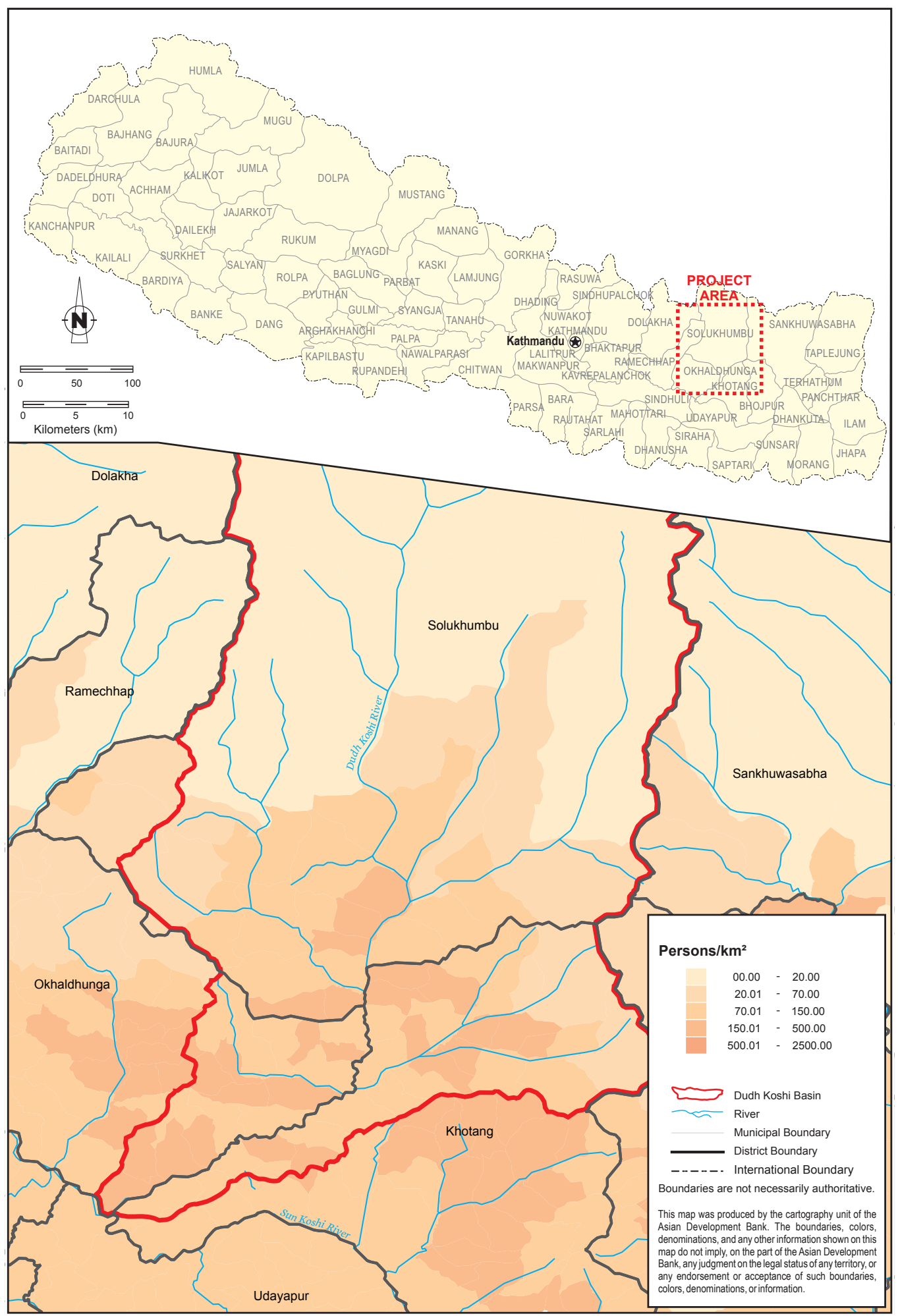

Source: ADB. 2016. Nepal: Operational Research for the Dudh Koshi River System, Final Report. Unpublished. 


\section{CHAPTER 2 Hydrology and Water Resources}

\subsection{The Hydrometric Network}

\section{Precipitation}

Because of the mountainous terrain, the density of the rain gauge and meteorological station networks in the Koshi River Basin (KRB) is low. The Department of Hydrology and Meteorology has no stations in the KRB at elevations above 2,000 meters ( $\mathrm{m}$ ). The lack of stations at higher elevations is a significant issue for the analysis, but an inescapable one in inhospitable mountainous terrain.

A precipitation versus elevation curve presented by Pokhrel et al. (2014) included the four Ev-K2-CNR climate stations in the elevation range of 2,500 $\mathrm{m}$ to $5,000 \mathrm{~m}$, and these indicated significantly lower annual precipitation at higher elevations. However, there may be a number of factors influencing rain gauge catch at higher elevations. Savean et al. (2015) concluded that precipitation is underestimated at higher elevations.

Recent work by Penton et al. (Commonwealth Scientific and Industrial Research Organization [CSIRO] 2016) explored several methods to estimate precipitation in Nepal, dealing with the sparse network of observations and lack of observations at high altitude. They adopted the Ensemble Spatial Data Imputation and Interpolation Model dataset, which is based on observed data for elevations of up to 3,000 m, and the Water and Global Climate Change (WATCH) dataset, which is based on reanalysis data for higher elevations. This is confirmed by other studies, such as Dahri et al. (2016), which showed that this approach performs better in the Hindu Kush Himalayan region than other comparable datasets. This CSIRO approach would be appropriate for future modeling studies.

\section{Climatic Data}

Climatic data are recorded at 11 stations in the KRB. Temperature and humidity are recorded at almost all stations, but wind speed is observed at only six stations, and solar radiation at only four. The continuity of data is generally slightly better than that for rainfall. As with the rainfall, there are no higher altitude climatic stations where most of the glacial melt and snowmelt take place; therefore, the study had to rely on lapse rate calculations.

\section{Stream Flow Data}

Figure 5 shows the network of stream gauging stations in the KRB. The continuity of stream flow data is discussed in the supporting water resources report. Issues were identified in 


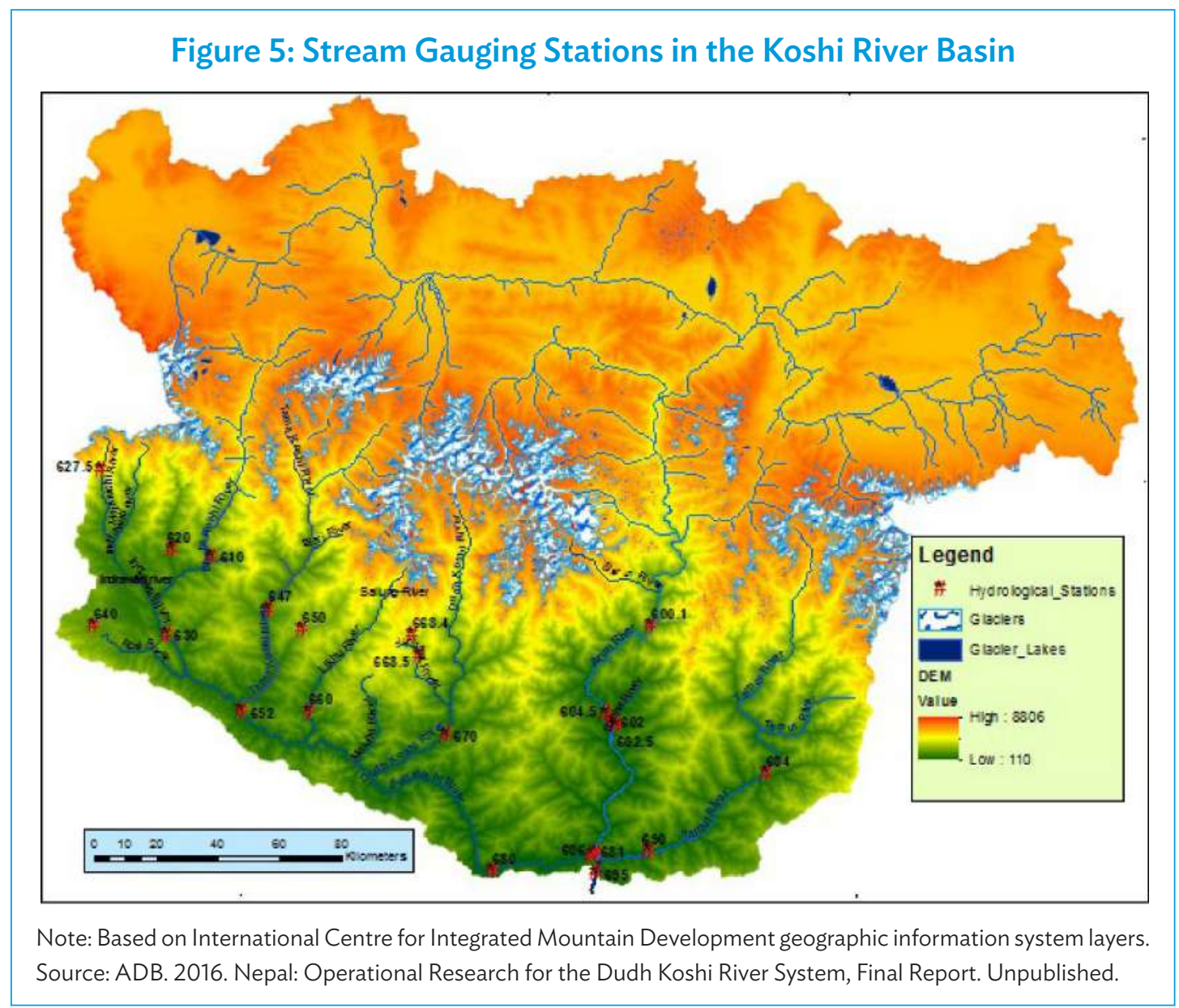

the data for several gauging stations-some relating to rating curve stability, and some to recorded station locations. A thorough review of stream flow data quality is recommended.

The flow record at Rabuwa Bazar (Station 670) on the Dudh Koshi is one of the longest available in the KRB. The time series analysis presented in the supporting report indicates more variability in annual runoff in recent years, but with no statistical evidence of trend. A more thorough analysis of data quality at Rabuwah Bazar is required, considering all rating data and identifying possible dates of shifts.

\subsection{Approach of the Dudh Koshi River System Study to Water Resources Assessment}

In view of the gaps in the available hydrometric data and the unavailability of observed stream flow data at all sites of potential water resources development, a hydrological simulation model was used to fill in the missing data, extend available stream flow data, and assess the potential impacts of climate change on runoff and river flows. A further simulation of water resources system was applied to assess the implications of different development scenarios on the river system and to quantify water resources potential including storage. 
The hydrological and water resources modeling carried out by the International Water Management Institute (IWMI) and the ICIMOD were considered as a strong platform from which to build the DKRS study. ${ }^{4}$ The Soil Water Assessment Tool (SWAT) set up by the IWMI has achieved good calibration throughout the KRB, and the Water and Evaluation Planning (WEAP) model is now widely used internationally in water resources planning. The IWMI provided the DKRS study with the SWAT model used in their phase 1 work (Bharati et al. 2014) for the KRB upstream of Chatara. The IWMI also provided the WEAP model from their phase 2 work (Chinnasamy et al. 2015).

\section{Soil Water Assessment Tool Model Refinements}

The SWAT model provided by the IWMI was set up to operate with observed precipitation and climatic data, with missing weather data to be filled through the built-in weather generator (WXGEN) stochastic routines in SWAT. The weather generation approach was extended to include all precipitation gauges used in the model.

The SWAT model can subdivide catchments by elevation zones. Up to 10 elevation zones can be specified, split either by equal area or by elevation increment. A temperature lapse rate can be specified (adopted value was $-4.5^{\circ} \mathrm{C}$ per kilometer $[\mathrm{km}]$ ) and the model calculates temperature for each elevation zone relative to the associated gauge temperature. This permits the model to better simulate snow accumulation and melt in a catchment.

\section{Water Evaluation and Planning Model: Refined Time Step}

The WEAP model established by the IWMI operated on a monthly time step and covered the entire KRB to its confluence with the Ganges. For the scale at which IWMI studies were directed, a monthly time step was appropriate, but for the more focused hydropower planning objectives of the DKRS study, a decision was made to reduce the time step to one-third monthly, and to truncate the model to consider only the KRB upstream of Chatara, for which the SWAT model was available.

For the KRB upstream of Chatara, irrigation demands are low, as are potable and industrial demands, and neither are likely to present significant demands in the future. The WEAP model was therefore simplified to consider only the river system downstream of potential storage hydroelectric projects on the Sun and Dudh Koshi river systems. This meant that the model ran more quickly, and the SWAT-simulated flows did not need any adjustment. The simplified model network is shown in Figure 6.

\section{Climate Change Scenarios}

The climate change scenario data used by Bharati et al. (2015) were provided by ICIMOD in the form of monthly delta change grids in temperature and precipitation for the 2030 s relative to the 1970s. The grid was overlain with the SWAT model sub-catchments and an index made of grid points was associated with each catchment. Catchment-averaged monthly

4 ADB. Nepal: Operational Research for the Dudh Koshi River System, Supporting Report on Water Resources. Unpublished. 
Figure 6: Simplified Water Evaluation and Planning Model Schematic

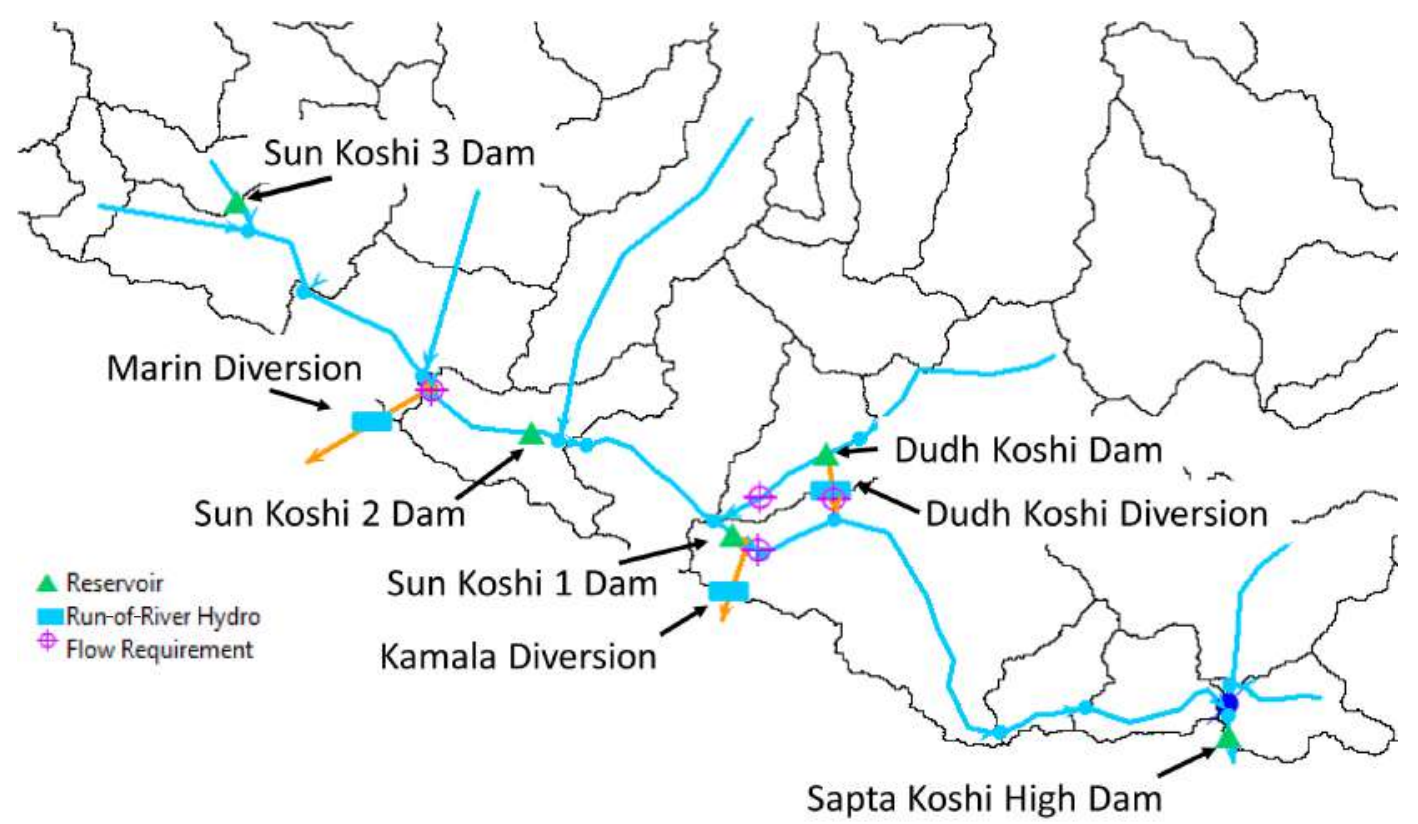

Source: ADB. 2016. Nepal: Operational Research for the Dudh Koshi River System, Final Report. Unpublished.

changes in temperature and precipitation were then created for each of the eight scenarios. ICIMOD selected models from a total of 43 that had RCP4.5 simulations and 41 that had RCP8.5 simulations. From the population of model runs, the differences in precipitation and in temperature were determined between the baseline and the 2030s. From these series of differences, the models that were closest to the 10th and 90th percentiles for precipitation and temperatures were chosen, to give combinations of dry:cold, dry:wet, wet:cold, wet:dry for each representative concentration pathway $(R C P)$, thus providing a series of boundaries within which future climate might lie.

\subsection{Soil Water Assessment Tool Model Calibration}

The SWAT model was recalibrated following a refinement of weather generation and the introduction of elevation banding and temperature lapse rates. Calibration was carried out using all available gauging stations - a total of 21 stations. The results of the calibration process are presented in full in the supporting water resources report. Acceptable model calibration could be achieved on larger catchments and at the basin scale. On some smaller catchments, errors in model input or observed stream flow meant that no sensible calibration could be achieved. Figure 7 shows calibration results on the Sapta Koshi at Chatara. Here, the volume simulation is within 2\%, and a Nash-Sutcliffe efficiency (SE) of 0.94 was achieved. On the Dudh Koshi at Rabuwa Bazar, the calibration was not as good, with a volume error of $11 \%$, and a Nash-Sutcliffe efficiency on $1 / 3$ month flows of 0.69 . For WEAP modeling, a composite flow record was used at Rabuwa Bazar. 
Figure 7: Calibration Results for Station 695 Sapta Koshi at Chatara
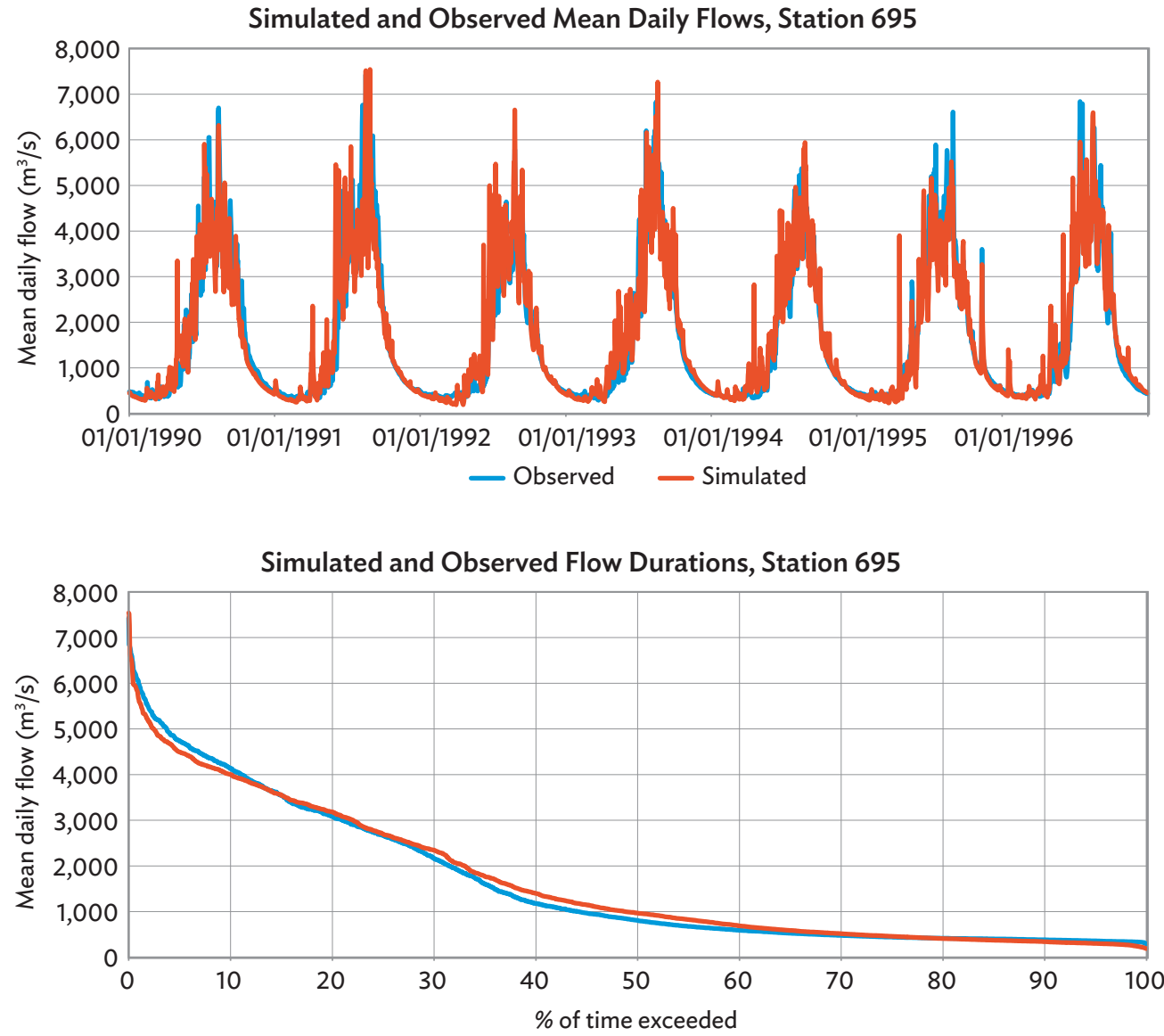

- Observed - Simulated

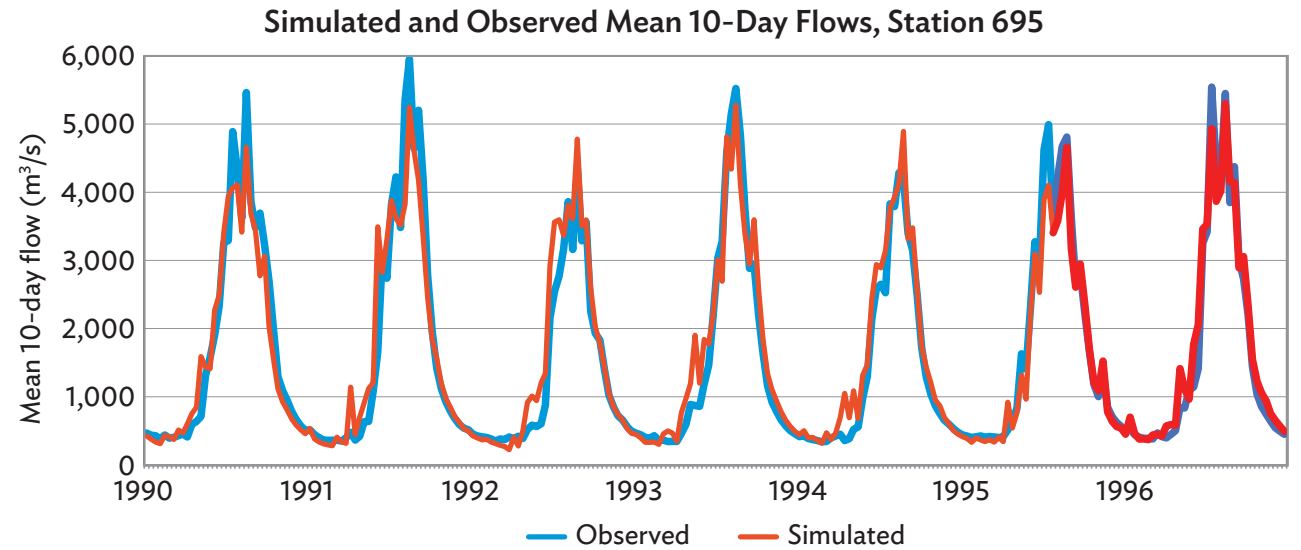

Source: ADB. 2016. Nepal: Operational Research for the Dudh Koshi River System, Final Report. Unpublished. 


\section{CHAPTER 3 Hydropower Development}

\subsection{Overview}

The Koshi River master plan study (KRMPS) sets out the development of Koshi River water resources and was prepared by the Japanese International Cooperation Agency (JICA 1985). A key feature of the plan was the creation of a cascade of reservoirs formed by high dams on the Sun Koshi for hydropower production and export, and the construction of a high dam on the Sapta Koshi upstream of Chatara that would provide export hydropower, flood control, and extended irrigation in the Terai.

One of the highly ranked development opportunities identified in the master plan was the construction of a storage dam on the Dudh Koshi for hydropower production, for which a feasibility study was conducted (Canadian International Water and Energy Consultants [CIWEC] 1998). The Nepal Electricity Authority (NEA) conducted several follow-up studies and started to update feasibility and design studies in July 2016.

A nationwide master plan study on the development of storage-type hydroelectric power in Nepal was prepared for the NEA with JICA support (J-Power 2013). The study focused on meeting electricity demands in Nepal to 2030 but did not consider exporting power.

\section{The Energy Situation}

In 2015, the Integrated Nepal Power System had an annual peak demand of 1,292 megawatts (MW), with $585 \mathrm{MW}$ of load shedding (45\% of demand) (NEA n.d.). Of the power supplied (707 MW), 68\% came from hydropower and of that, $26 \%$ was from independent power producers. The remaining $224 \mathrm{MW}$ was imported from India. In the 2015 fiscal year, NEA had a total installed capacity of $523 \mathrm{MW}$, of which $89.7 \%$ was hydropower.

The Electric Power Development Co. Ltd. (J-Power) developed a power and energy demand-forecasting model based on sectoral gross domestic product growth rates. Annual base case energy demand was forecast to increase to 19,493 gigawatt-hours by 2032 and peak load to increase to 4,279 MW. These are significant increases, which are expected to be met by a combination of storage and run-of-river hydropower projects. The J-Power study recommends that 2,644 MW of the 2032 peak demand be met by storage hydropower projects. 


\subsection{Hydropower Planning for the Koshi River Basin}

The Dudh Koshi River System study focuses on hydropower planning in the Dudh and Sun Koshi River systems, and includes an assessment of seven major hydropower projects, which affect or are affected by the Dudh Koshi Storage Hydroelectric Project (DKSHEP) the DKSHEP, Sun Koshi 1, Sun Koshi 2, Sun Koshi 3, Sun Koshi Marin Diversion, Kamala Diversion, and Sapta Koshi High Dam (including the Chatara barrage).

\section{Koshi River Master Plan Study}

The 1985 KRMPS aims to prepare a comprehensive water resources development plan for the Koshi River. The master plan intends to benefit Nepal as a priority, but the developments proposed would also have considerable downstream benefits. To determine the hydropower development potential, the study identified 52 project sites with minimum capacities of over $10 \mathrm{MW}$. Of these, 36 project sites were located in the Sun Koshi Basin where the overall hydropower potential was identified to be 5,013 MW.

The master plan has identified potential irrigation in the Terai from the Koshi Basin of 474,800 hectares (ha) in six sub-areas. The potential area identified between the Bagmati River and the Sapta Koshi was 403,300 ha, and the area east of the Sapta Koshi was 71,500 ha.

Priority schemes identified by the master plan include 1 multipurpose scheme with irrigation and hydropower production, and 13 hydropower schemes, 5 of which are high dam projects. The multipurpose scheme is a diversion from the Sun Koshi to the Kamala River, with 175,100 ha of irrigation and an installed hydropower capacity of $93 \mathrm{MW}$. The high dam projects include the Sapta Koshi High Dam, Sun Koshi No. 1, Sun Koshi No. 2, Sun Koshi No. 3, and Tamur No. 1. The projects on the Sun Koshi are most relevant to the Dudh Koshi project (Figure 8).

The Sun Koshi multi-purpose project comprises the Sun Koshi No. 3 dam, the Sun Koshi diversion, the Kamala dam, and the associated irrigation development in the Terai. The project may consist of two phases. Phase 1 may involve construction of (i) the Kurule diversion dam and a 16.6-kilometer tunnel linking to the Kamala River; (ii) the Kamala dam; (iii) 61.4 MW of installed capacity at a diversion power station and $32 \mathrm{MW}$ of installed capacity at the Kamala dam; and (iv) 175,100 ha of irrigation on the Terai. The Sun Koshi No. 3 dam may be constructed in phase 2, which consists of a 140-meter high dam providing 1,220 million cubic meters $\left(\mathrm{Mm}^{3}\right)$ of gross storage, $550 \mathrm{Mm}^{3}$ live storage, and with an installed generating capacity of $536 \mathrm{MW}$.

The master plan proposes a cascade of reservoirs for the Sapta Koshi and Sun Koshi rivers, with the high water level from downstream reservoirs almost reaching the toe of the next upstream dam. Figure 9 shows the profile of the cascade for the Sun Koshi. The high water level of the Sun Koshi 1 reservoir extends to a point 3 kilometers $(\mathrm{km})$ downstream of the Dudh Koshi powerhouse location proposed by the KRMPS. 


\section{Figure 8: Proposed Developments of Relevance} to the Dudh Koshi Dam Options

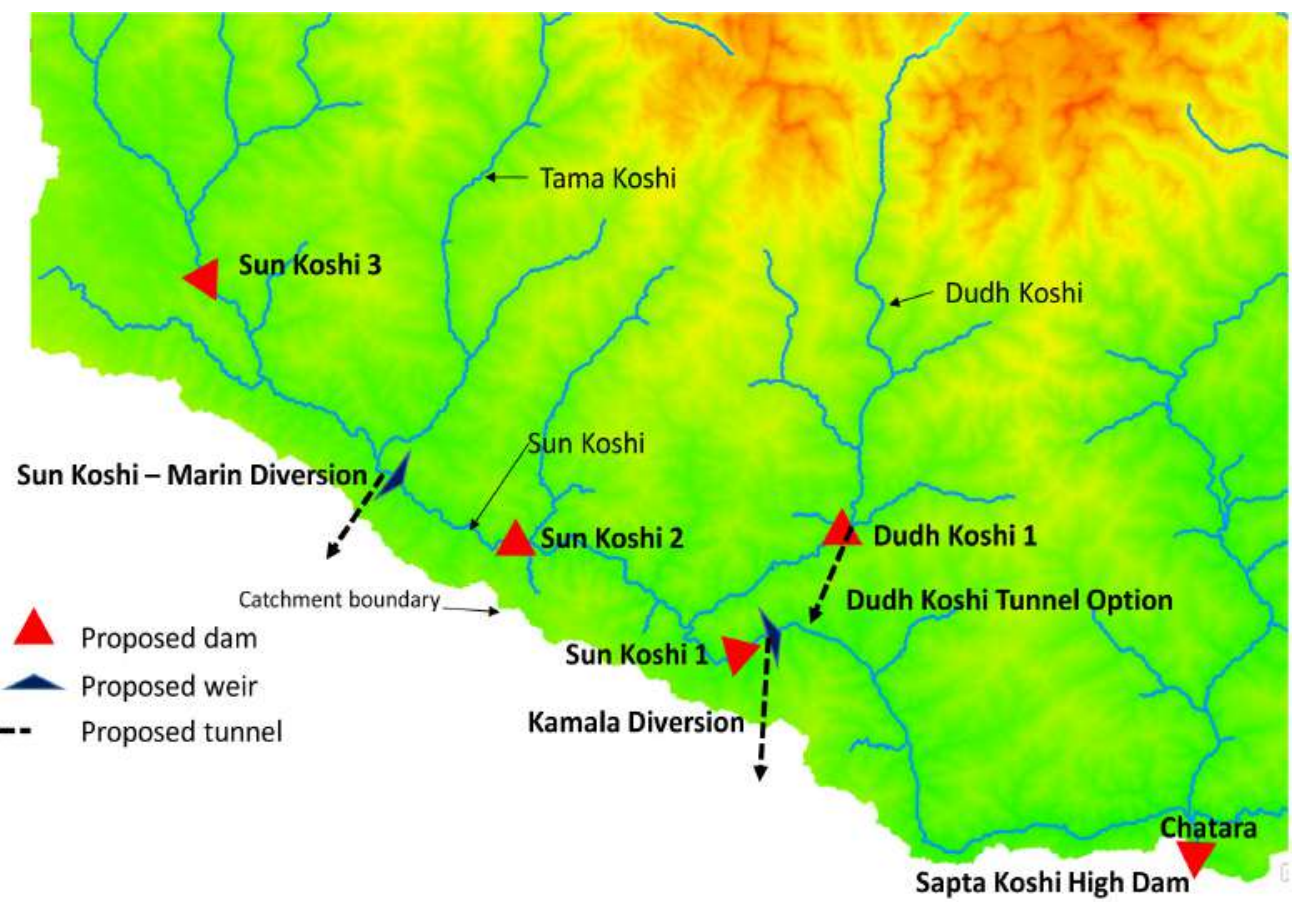

Note: Based on International Centre for Integrated Mountain Development geographic information system layers. Source: ADB. 2016. Nepal: Operational Research for the Dudh Koshi River System, Final Report. Unpublished.

Figure 9: The Reservoir Cascade Proposed by the Koshi River Master Plan Study, 1985

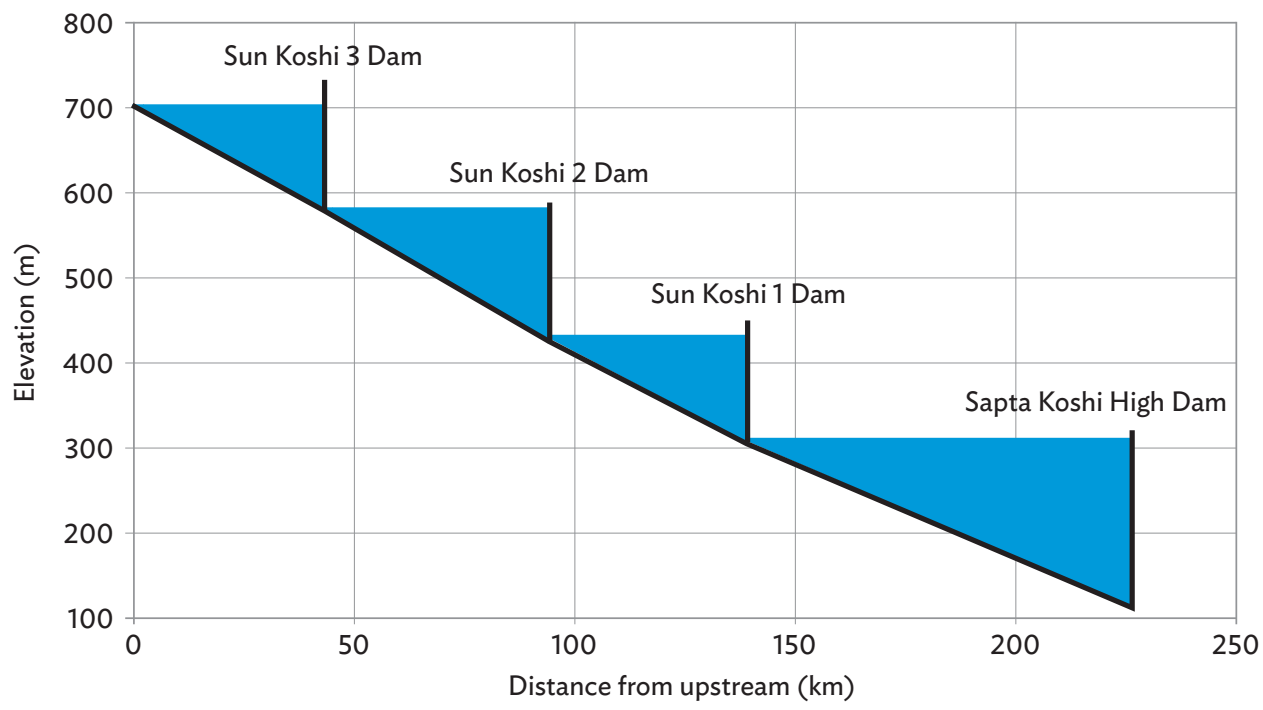

$\mathrm{km}=$ kilometer, $\mathrm{m}=$ meter.

Source: ADB. 2016. Nepal: Operational Research for the Dudh Koshi River System, Final Report. Unpublished. 


\section{The Dudh Koshi Storage Hydroelectric Project}

The 1985 JICA master plan includes a proposal to construct a 104-meter high dam on the Dudh Koshi with a 2.6-kilometer long tunnel leading to the powerhouse downstream of the dam. The scheme was considered a peaking run-of-river scheme with an installed capacity of 228 MW. In 1998, CIWEC conducted a feasibility study for the DKSHEP. ${ }^{5}$ The feasibility study offers two options: (i) a powerhouse at the tow of the dam as in the KRMPS (Scheme A) and (ii) a powerhouse located at the end of a 13.5-kilometer headrace tunnel discharging to the Baikhu Khola, a tributary of the Sun Koshi about $26 \mathrm{~km}$ downstream of the proposed Kamala diversion dam at Kurule (Scheme B). This option provides an additional $120 \mathrm{~m}$ of head.

The NEA prepared project progress reports in January 2015 and January 2016. A contract has been let for the updated feasibility study, environmental and social impact assessment, and detailed engineering design, including bidding documents preparation of Dudh Koshi Storage Hydroelectric Project; the consultant commenced in July 2016.

\section{The Sun Koshi-Marin Diversion Project}

The Sun Koshi-Marin Diversion Project would transfer up to 77 cubic meters per second $\left(\mathrm{m}^{3} / \mathrm{s}\right)$ from the Sun Koshi just upstream of Khurkot to the Marin River, a tributary of the Bagmati River. This was not identified in the KRMPS. The project consists of a 2-meter high, 180-meter long weir across the Sun Koshi that will divert water to the Marin River through a 13.2-kilometer long 9-meter diameter tunnel. Hydropower would be generated at the downstream end of the tunnel with an installed capacity of $36 \mathrm{MW}$. Annual energy generation is expected to be 303 gigawatt-hours (GWh).

The impact of the proposed Sun Koshi-Marin Diversion Project on river flows in the Sun Koshi downstream of its confluence with the Dudh Koshi has not been considered in any of the Dudh Koshi studies carried out so far. With the development of the Sun Koshi-Marin Diversion Project, dry season flow availability at the site of the proposed Kamala diversion could be reduced significantly.

5 Canadian International Water and Energy Consultants (CIWEC). 1998. Dudh Koshi Hydroelevtric Project: Feasibility Study. Kathmandu: Nepal Electricity Authority. 


\section{CHAPTER 4 Irrigation}

\subsection{Existing Plans}

The Koshi River master plan study (KRMPS) has identified various options to develop surface water irrigation by diverting water from Sun Koshi at the Kurule barrage site to the Kamala River to irrigate a total net area of 278,000 hectares (ha). The KRMPS estimates that the available flow in the Sun Koshi could irrigate 113,000 ha without Sun Koshi 3, or 153,000 ha if the Sun Koshi 3 project were constructed. To balance the shortfall, the study proposes that the Kamala storage dam and reservoir be built on the Kamala River with live storage of around 456 million cubic meters $\left(\mathrm{Mm}^{3}\right)$. The study proposes to divert 72 cubic meters per second year-round flows through the diversion tunnel with an effective head of 102 meters $(m)$.

The more recent joint project office studies have built on the 1985 KRMPS and proposed an expanded area for supplementary irrigation supply from the Koshi River covering 11 districts with an estimated gross area of 830,000 ha and net area of 682,000 ha. ${ }^{6}$ The benefit area includes 10 major irrigation schemes with a net command area of 262,000 ha and a net minor irrigation and unirrigated area of about 418,000 ha. Surface water irrigation is currently from tributary rivers without storage, and although there is good wet season water availability, irrigation water is scarce during the dry season. Water use efficiencies are low, with typically only about $30 \%-40 \%$ of the command areas irrigated by surface water during the dry season. Groundwater is used increasingly to meet the shortfall within the irrigated areas. Figure 10 shows these potential irrigation areas.

\subsection{Irrigation Development}

Developing surface water irrigation in the Terai is complex and expensive. The main canals are very large, running in east-west direction and major investment would be required for river crossings, cross drainage, and land acquisition. Many of the tributary rivers are natural rivers with no bank protection or training works, and the river courses change with each flood. River training will require major investment. Most of the main canal alignments would be formed on the highly permeable soils of the Sivalik range and would require lining.

Large-scale agency-managed schemes in the Terai have performed poorly, particularly toward the tail end mainly because of weak management institutions, poor upkeep of canals

6 From west to east, there are eight districts: on the west side of the Sapta Koshi River are Parsa, Bara, Rautatahat, Sarlahi, Mahotari, Dhanusha, Sirha, and Saptari; and three districts on the east side of the Sapta Koshi: Sunsari, Morang, and Jhapa. Data sourced from the Joint Project Office-Sapta Koshi Sun Koshi Investigation Office. 


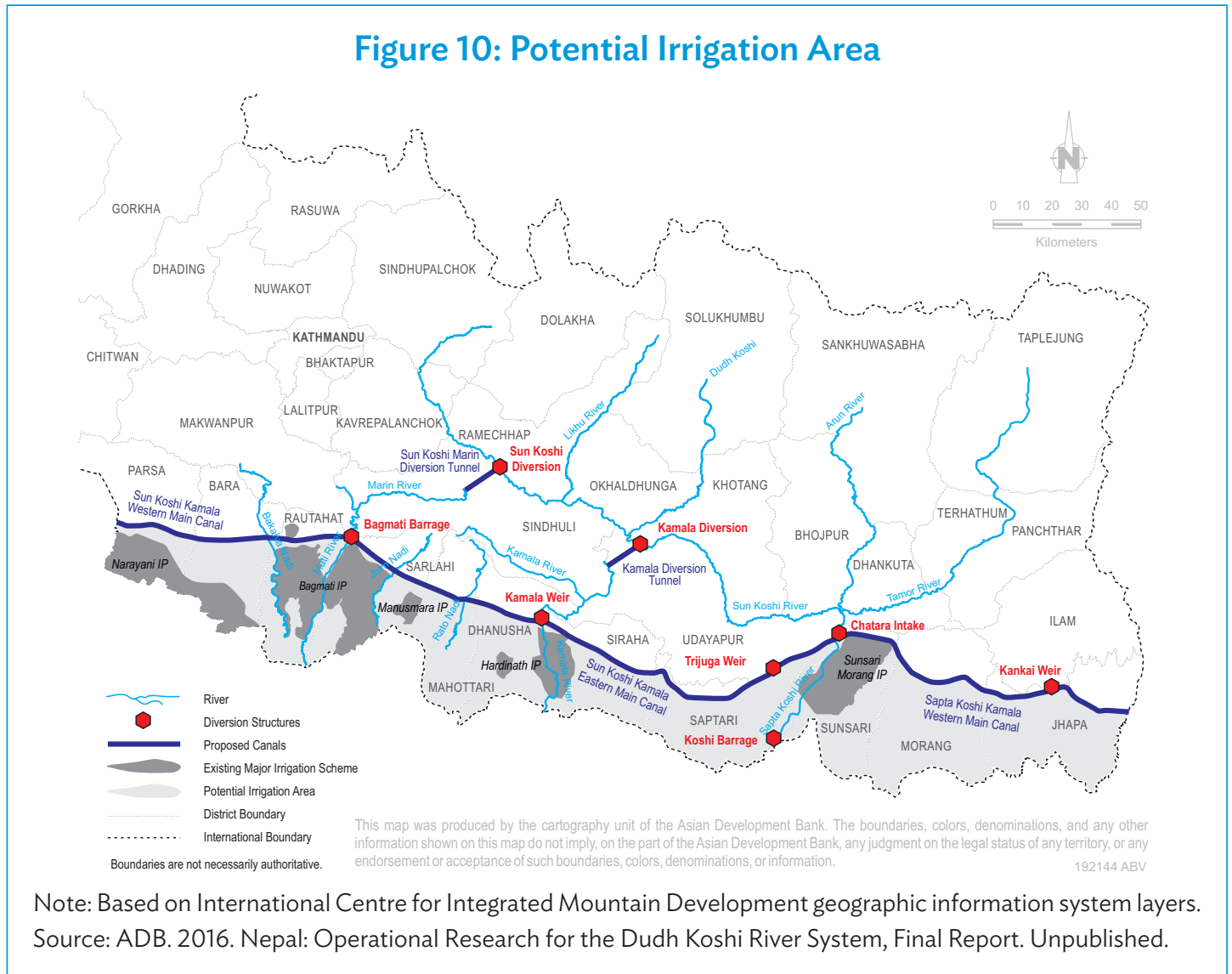

and structures, and high levels of siltation. A shortage of males resulting from out-migration has further aggravated the situation. The active participation of more women is critical in both farming and irrigation management.

Recharge from surface water irrigation is raising groundwater tables, making waterlogging a risk in parts of the Terai. This problem will worsen significantly if additional surface water is diverted from the Koshi River, posing a potential major risk to agriculture on the eastern Terai over the long term. Conjunctive management of surface and groundwater can reduce issues of waterlogging.

\section{Groundwater}

The poor condition of the surface water canals and the lack of a systematic allocation system have resulted into many areas not receiving water. Even in the wet season, some areas do not receive water supply. Groundwater is used extensively to meet the deficit. According to the Ministry of Agricultre and Livestock's land use statistics, about 25\% to 30\% of the agricultural land is estimated to be using groundwater either to supplement surface water supplies or as a stand-alone source.

The aquifer system is recharged from both natural and man-made sources. Overall, the potential recharge to the irrigation areas in Terai is considerable, giving good scope for increased groundwater use for irrigation where aquifer conditions are favorable. 
Groundwater is pumped with diesel pumps; and farmers report the high costs of pumping as a major constraint. Farmers are already entitled to free tube wells if they form a water user association, but while there are pocket areas where the projects have been successful, farmers face many constraints. The approaches to subsidizing groundwater are not achieving the targeted benefits. New approaches with lower levels of subsidies need to be developed to distribute benefits to a larger section of society.

The ample availability of both surface and groundwater resources allows for flexibility. Minimizing energy use is an important consideration for a farmer who wants to reduce the costs of farming. For the government, links to national energy policy and planning need to be considered, especially if electric power is used.

The extremely productive aquifer in most parts of the eastern Terai offers a good potential to further develop the groundwater irrigation. Modernizing the surface water irrigation can enhance expansion and intensification activities. Achieving cheaper power by supporting electrification of pumps and subsidized power tariffs is considered an effective approach to support groundwater irrigation.

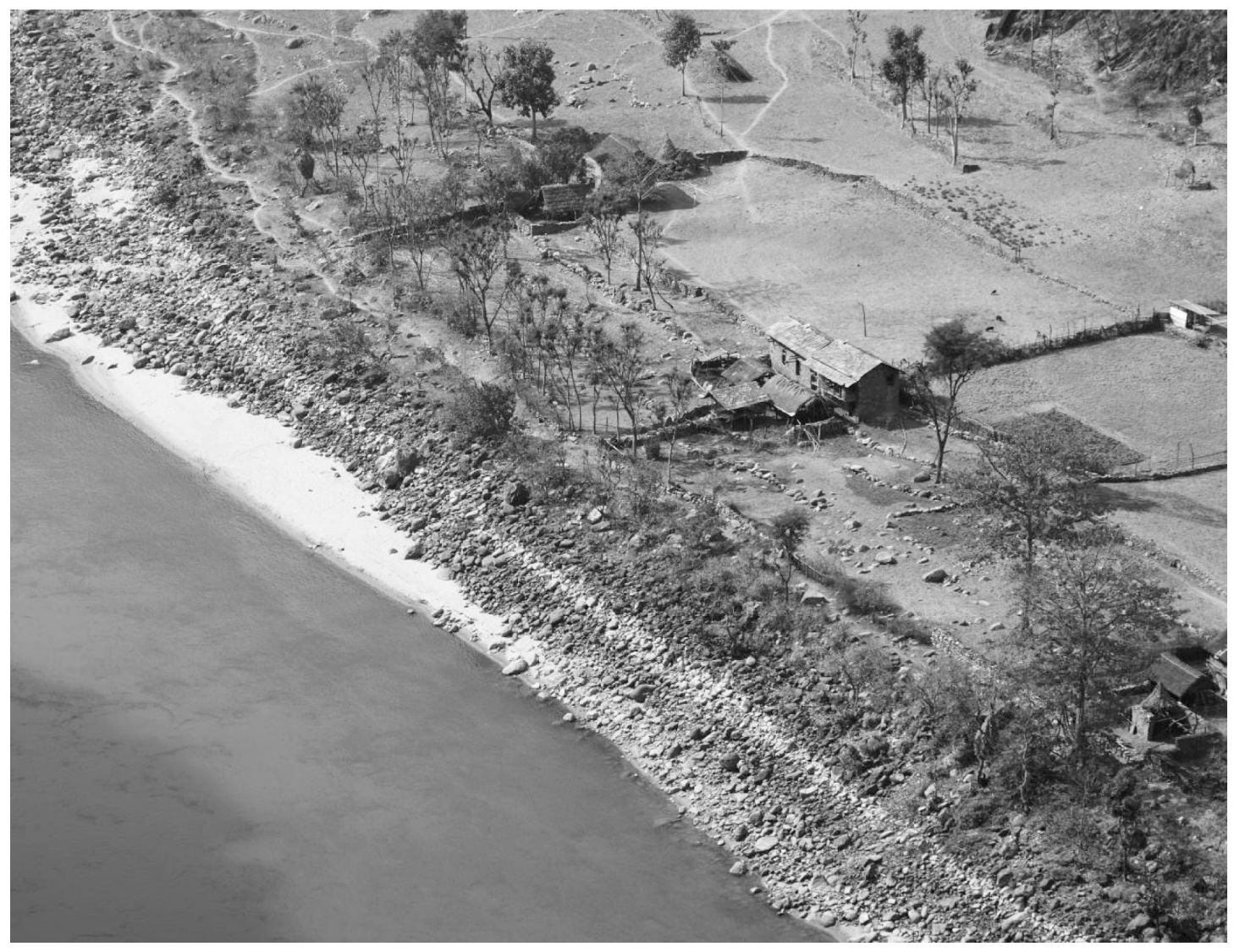

A view downstream along the Sun Koshi-Marin irrigation and hydropower diversion offtake. River flows and water levels in the Sun Koshi will be significantly impacted by hydropower projects. 


\subsection{Agriculture}

Agriculture in the Terai is well below its potential largely due to unreliable irrigation, poor returns from crops, high costs of input including that of pumping groundwater, lack of markets, and the low percentage of tenant farmers; there is also significant competition with Indian farmers who benefit from high subsidies.

Proposals for modernizing irrigation need to incorporate significant parallel agricultural investments that would support the establishment of intensive, professionalized extension services. An ADB study proposes the creation of a fund to support agriculture initiatives, which should be around 10\% of the cost of infrastructure. These investments will help increase crop yields and produce better financial returns, particularly for a faster uptake of new agricultural technologies and improved on-farm water management. Agriculture support programs can be effective and more sustainable if they are based on commercial activities adopting public-private partnerships-with seed money for start-up costs supported as part of an integrated investment program. 


\section{CHAPTER5 Environmental and Social Impacts}

The environmental impacts of hydropower development in the basin will be significant, and will include major changes to the river flow and morphology, which will affect fisheries and aquatic biodiversity. The standards for environmental flow are not well defined, and appropriate emphasis must be given to aquatic habitat surveys and assessments. The default criteria for hydrological environmental flow are significantly lower than international practices and could leave some of the finest rivers effectively dry.

Communities were interviewed and consulted and were found to respond positively to the proposed hydropower developments especially with the potential for job opportunities and improved roads to markets and their homes. They expected these developments to improve socioeconomic conditions, but expressed concern over the perceived long delays in implementation, lack of information and local participation in the planning process, and the potential impacts on the environment. In the Solukhumbu District where hydropower development is ongoing, mechanisms to address stakeholder expectations were unclear, complaints were not addressed, and liaison with the developers was not effective.

Local communities desire to be consulted and heard and, as indirectly affected persons, they do consider themselves as stakeholders with rights over and above their landholdings and any direct displacements. Community perceptions of the hydropower projects are complex as the interests of different community groups vary widely. Because many local community residents work abroad, mainly in the Middle East, reaching consensus is difficult. In general, the stakeholder consultations indicated that the environmental and social impacts of hydropower could be mitigated at lower elevations. However, limiting the development of hydropower at higher elevations should be considered because the impacts of construction could disturb highly sensitive ecosystems. A proposal to limit hydropower development to elevations below $2,500 \mathrm{~m}$ was made in response to stakeholder consultations.

\subsection{Fisheries}

The proposed development of hydropower in the KRB will have major impacts on the river's aquatic ecosystems. Fisheries are affected by anthropogenic impacts including poor fishing practices (e.g., electric fishing), increased sediment, and the partial blockage of fish migration at the Koshi Barrage on India's border. The environmental impact assessments do not consider other possible developments and the impact of cascade systems. At full development of the KRB, the river will transform from a largely natural river system 
to an almost fully regulated system with cascades of reservoirs and river diversions. Core issues include the following:

(i) Maintenance of environmental flows. Nearly all environmental impact assessments propose $10 \%$ of the average monthly low flows as specified in the hydropower policy, which is significantly less than international norms. Approaches to defining environmental flows in Nepal should be assessed and considered carefully. For instance, compliance with the environmental flow requirements should be ensured, and gravels for construction should not be extracted from natural riverbeds.

(ii) Large fluctuations in river flows. These can be harmful. Studies have shown that flushing of desilting basins and peaking discharges can have major impact on the river ecology and fish stocks, especially juvenile fish.

(iii) Screens at water intakes. Installing screens at intakes can prevent fish from being trapped and passed through turbines.

(iv) Fish pass. For large dams, a fish pass is generally deemed not feasible; for the small run-of-river schemes with low-level barrages, fish passes are sometimes included. In Nepal, fish passes have been installed at several projects including the Koshi Barrage. Good quality monitoring data is not available but, in general, performance is poor and provision of a hatchery is often proposed as an alternative to fish passes. However, there remains very limited information on the performance of hatcheries.

(v) Fish trapping and hauling. This involves trapping of fish below the dam and transporting them to the reservoir or further upstream to maintain fish diversity and gene pool. ${ }^{8}$

(vi) Fish lift. A fish lift is expensive but allows some passage at high dams and would allow a limited extent of migration.

(vii) Fish hatchery. A reservoir-associated hatchery can produce seed of important native fish. Stocking the reservoir and tail water will replenish the losses resulting from the disappearance of the natural spawning grounds and from secession of migrations. A hatchery can also provide fishermen with fry and fingerling for growing fish in ponds or cages to market size. This provides an alternative means of subsistence and income, thus reducing the pressure of the capture fishery on native stocks. Hatcheries can also breed selected non-native species that are easier to breed and that have better growth potential than native species such as the silver bighead carp or trout. Hatcheries require technical skills, an adequate budget, and a strong institutional organization to manage fisheries.

(viii) Stocking of reservoirs. This can provide reasonable levels of production, which can be enhanced by cage culture. It is essential to stock with triploid or sterile fish to avoid introducing self-breeding species that would compete with the native species and pose a serious threat to biodiversity.

(ix) Sport fishing. In India and Pakistan, the commercially important mahseer species have become well established in reservoirs, providing an opportunity to develop a fisheries industry through sports fishing.

8 Food and Agriculture Organization of the United Nations. 2002. Cold Water Fisheries in the Trans-Himalayan Countries. http://www.fao.org/docrep/005/y3994e/y3994e0j.htm. 
Although fish biomass can be maintained, the species composition may change. In general, indigenous fish species are more difficult to breed and have less productive growth potential than some non-indigenous species. The benefits of reservoir fisheries need to be ring fenced and special initiatives set up to ensure that river fishermen are given priority and support for the reservoir fisheries and culture activities. Fisheries need to be managed based on a complete river system and not by individual projects.

Over and above the immediate impacts on fishing communities near the proposed hydroelectric power project sites, reduced flood flow will affect the fishing and floodplain agriculture in the Terai. Fishing is an important livelihood for the landless and land-poor households in the floodplain areas and is ranked the second most important source of livelihood after agriculture.

\subsection{Social and Cultural Impacts}

Large hydropower schemes will have significant impact on local communities. Direct impacts include loss of land and property. Indirect impacts include decay of social cohesion, economic instability, threats to cultural integrity, and degradation of roads and water infrastructure, as well as impacts on biodiversity, health from dust and noise during construction, migrant labor and competition for jobs, and risks for small local enterprises.

As a whole, local communities do not benefit directly and significantly from hydropower development. While some parts of the communities do benefit, many see limited or no benefit and others lose out. Communities have several initiatives to share project benefits but this in itself can be a source of tension.

\section{Community Needs}

Despite the requirement to incorporate community needs in the development of hydropower projects, very little action or planning is done in various hydropower and water policies to address the needs of the affected communities. Local disputes over the development of large infrastructure projects have been widely reported as projects have failed to meet the communities' expectations and interests. Despite some effort, the state still needs to better understand community expectations and improve its capacity to address them.

\section{Involuntary Resettlement}

Involuntary resettlement covers the area that is directly affected by the dam construction and the inundation area of the reservoir. To compensate for the loss of assets, offering alternative landholdings for vulnerable people whose pre-project livelihoods depend on land will be prioritized. Where replacement land is not available, alternative arrangements need to be made.

Table 2 gives a summary of resettlement requirements estimated for the key projects. Who loses out in the context of inundation is complex, and needs to be thought out when compensation is considered. Those who may lose land are often the richer households, but 
Table 2: Estimate of Resettlement Requirements for Key Hydroelectric Power Projects

\begin{tabular}{|c|c|c|c|c|c|c|}
\hline & Settlements & $\begin{array}{l}\text { Households } \\
\text { (persons) }\end{array}$ & Land $\left(\mathrm{km}^{2}\right)$ & Buildings & $\begin{array}{c}\text { Blacktop } \\
\text { road }(k m)\end{array}$ & $\begin{array}{c}\text { Gravel road } \\
(\mathrm{km})\end{array}$ \\
\hline Dudh Koshi & 9 & $63(448)$ & 11 & 234 & 0 & 5 \\
\hline Sun Koshi 2 & & $\begin{array}{r}2,467 \\
(6,492)\end{array}$ & 83 & $\sim 2,700$ & $\sim 90^{\mathrm{a}}$ & $\ldots$ \\
\hline Sun Koshi 3 & 31 & $\begin{array}{r}1,599 \\
(11,075)\end{array}$ & 31 & 1,238 & 15 & 24 \\
\hline Sapta Koshi & 301 & $(75,000)$ & & & & \\
\hline
\end{tabular}

the real losers could be the tenants who work on the land. The effect on the whole basinand not just on landowners - needs to be considered (Sugden 2016).

Many issues relate to involuntary resettlement, thus resettlement planning and addressing the issues are both critical. While most of the communities are positive about the new projects and their potential benefits, those affected directly will have a different perspective. This disparity between winners and losers is one of the main social problems in major infrastructure projects. Interviews with a sample of families likely to be displaced by the Dudh Koshi Storage Hydroelectric Project indicated their preference to remain in the area.

\section{Community Perceptions of Hydropower in the Dudh Koshi Basin}

The results of stakeholder interviews and focus group discussions in different village development committees are quite consistent. Communities were seen to be generally supportive and positive toward the planned and ongoing investments and expected improvements in the local economy as well as some beneficial social impacts. The stakeholder surveys include questions on the stakeholders' perceptions of hydroelectric power projects. Key observations are as follows:

(i) Directly affected families must be given adequate compensation and support for resettlement. Every effort should be made to support local resettlement.

(ii) Reservoir inundation and impacts on river fisheries have a mix of negative and positive impacts. The respondents generally considered the reservoir to have a potential benefit to fisheries and tourism. The impact on river fisheries was generally not perceived to be a problem; however, there was no real representation of fishermen in the sample interviewed.

(iii) The impact on the environment was seen as moderately negative; there was concern about the impact on trees and potential noise pollution. Views on the impact of migrant labor were mixed. Some respondents saw the advantage of migrant labor to the local economy. 
(iv) The communities in all three districts had positive perceptions of and clearly high expectations for job opportunities during and after construction. In Solukhumbu, where several hydropower projects are being constructed, skilled labor is brought in from outside the local area. Local labor is engaged for unskilled positions, and most jobs are for intermittent periods.

(v) Hydropower-together with upgraded electricity supply-was perceived to result in improved roads that would benefit and help support tourism.

(vi) Knowledge on hydroelectric power projects is very limited in the DKRS, with only $10 \%$ of the respondents claiming that they had good knowledge on those projects. With people keen to learn more about the programs, conducting awareness training is important.

(vii) Nearly all the groups wanted to establish a community-based organization to represent their interests.

(viii) Some respondents felt that hydropower could result in increased disputes within the community.

\section{District Development Committees}

The district development committees (DDCs) play an important but unrecognized and under-resourced role in hydropower planning and management. In general, the DDCs felt that they were insufficiently involved in planning the hydroelectric power projects, and that the hydropower developers have not engaged with the communities effectively.

No guidelines have been set for the role of the DDC or village development committee in the planning and construction stages of hydropower development projects. The mechanism for dispute resolution is not clear. Even though the central government and developers do not involve them, the DDCs' support will likely be required in resolving disputes. Insufficient resources, funding, and technical staff prevent the DDCs from monitoring projects or supporting community engagement.

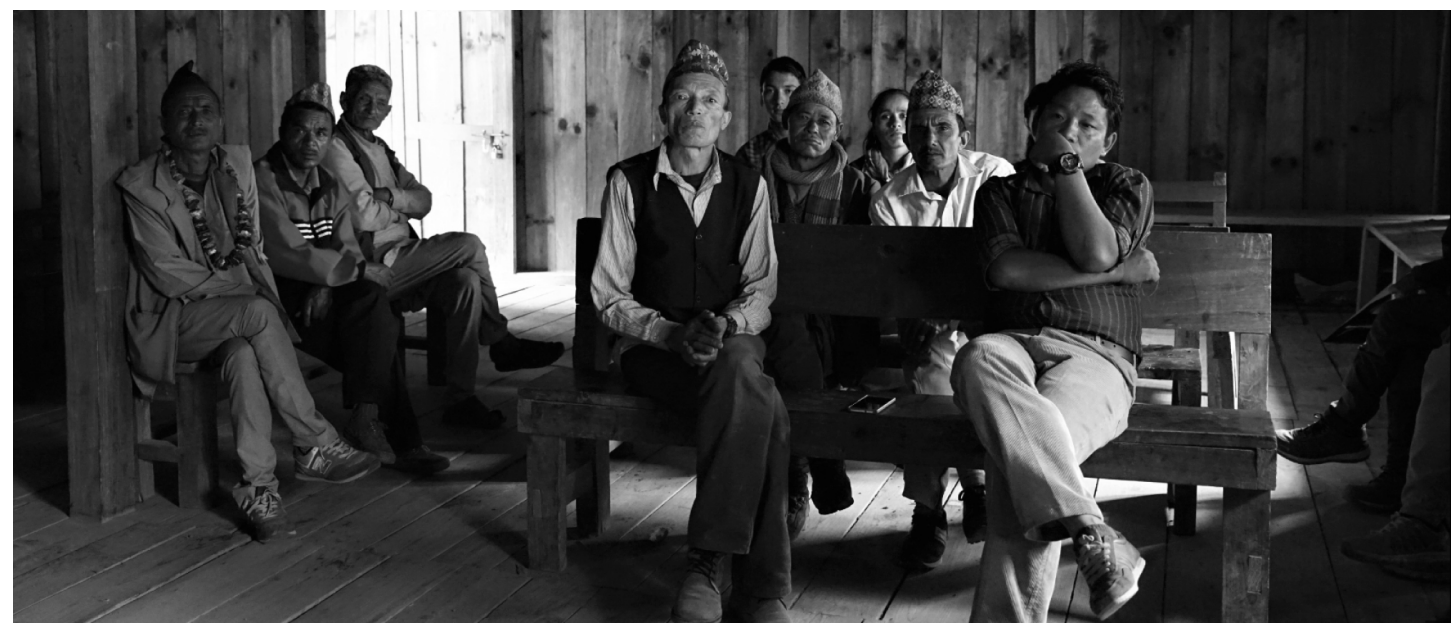

The ADB team hold stakeholder consultations on the Dudh Koshi sub-basin. The study carried out extensive consultations with communities along the length of the Dudh Koshi to understand their perceptions of hydropower projects and other development issues. 


\section{CHAPTER 6 \\ Strategies for Integrated Development of the Dudh Koshi Sub-Basin}

\subsection{Benefit Sharing}

Government policy is clear on involving communities in hydropower planning and on ensuring that they also receive some of the development benefits. Development programs in the basin need to be carefully identified and planned in coordination with hydropower investment.

Benefit sharing can help make hydropower development equitable, sustainable, and implemented smoothly. Several initiatives in Nepal enable communities to share project benefits but this in itself can be a source of tension and subject of dispute between investors and local communities. Legal provisions for project benefit sharing in communities are lacking and a subject of negotiation between investors and local communities; and without an arbitrator, disagreements can frequently lead to conflicts.

\section{Royalties}

The Government of Nepal defines the concept of benefit sharing in its various hydropower policies. The 2007 amendment to the hydropower policy made provisions for $12 \%$ to the district development committee (DDC) adjoining the projects, $50 \%$ to support the national treasury, and $38 \%$ as a regional share. The $12 \%$ allocation to the DDC should be split into $50 \%$ for environmental protection in the upstream areas, $20 \%$ for supporting the projects' infrastructure (dam, powerhouse, and reservoir), 15\% for downstream dry areas below the dam, and 15\% for other uses. In practice, however, the DDC makes its own decisions on the allocations.

\section{Corporate Social Responsibility by Developers}

To some extent, hydropower developers do fund local communities as part their corporate social responsibility, which can be considered benefit sharing. The developer is not obliged to support the communities, and defining the type, size, and spatial boundaries of allocations can create significant problems.

Typically, local persons are hired for unskilled tasks whereas the bulk of recruitment is for semi-skilled and skilled labor mainly from outside the area, at higher pay rates. Increasing local recruitment is an important aspect of corporate social responsibility. Construction jobs cover the construction period only and opportunities after completion are limited. Properly managed employment during construction can provide skills that are useful after the construction period. However, there are limits to what developers can provide as part 
of their corporate social responsibility and many developers feel that the project-affected communities are making too many demands.

\section{Equity Shares to Local Communities}

The Securities Registration and Issue Regulations 2008 states that 10\% of shares floated for private sector hydro schemes should be made available for the local community and $15 \%$ to the public. ${ }^{9}$ Locals cannot sell shares for the first 3 years.

Share allocations have been popular and many share issues are oversubscribed. Shares are issued only by public limited companies as a means to raise capital but also to help obtain goodwill from the communities. The equity shares differ from royalties in the following aspects: (i) shares benefit individuals, not the communities; (ii) little or no government mediation is required; (iii) share values can increase and decrease in value, which is not well understood by the local communities; (iv) in the communities, there are non-shareholders and small and large shareholders, which create a vested interest in the performance of the shares against the communities' long-term needs; ( $v$ ) shares are meant for local and projectaffected communities, and assessing who is local creates some challenges; and (vi) lowincome and indigenous groups find it hard to raise capital and sometimes borrow to raise capital for share issues, which has a high risk.

There are some issues with the share schemes wherein private companies and government enterprises do not have to issue shares - which can be confusing to communities who do not understand the corporate arrangements. For large-scale schemes, such as the Dudh Koshi Storage Hydroelectric Project (DKSHEP), there is currently no plan to issue shares to local investors.

\section{Allocation of Costs and Benefit Sharing}

Shared benefits should be allocated based on an analysis of the needs, benefits, and agreements with the principal stakeholders. Some of the benefits to the communities actually also benefit the developer. For example, activities such as catchment management and road construction provide financial benefit to the developer as well as to the environment and socioeconomic development of the districts.

A significant issue with royalties is the slow buildup of payments. Royalty payments are not made until the scheme becomes operational, and payments over the first 15 years are currently $18 \%$ of the full amount. This delay in royalties is frequent and has significant impact on the communities. Many communities have not benefited from royalty payment even several years after the completion of the project. Programs such as catchment management also need to be initiated as early as possible to maximize the benefits. This is especially important for planting programs that have very slow buildup of benefits, and road programs are best developed at a very early stage to help support the heavy construction traffic.

9 Securities Board of Nepal. 2008. Securities Registration and Issue Regulations. http://sebon.gov.np/sites/default/files/ securities_laws/Securities/ssueRegulationEn.pdf. 
Defining which communities should share the benefits from hydropower is difficult and poses problems for the district administrations. Hydropower impacts are not equal; and because communities from both inside and outside the catchment are affected in different ways, community perceptions should be considered. Catchment management clearly needs to be focused on the critical parts of the catchment upstream of the investments. However, for other initiatives such as roads, agriculture, and electricity, communities expect that benefits are shared throughout the districts where the schemes are located, even though some communities may not be located in the scheme catchments.

\subsection{Development Priorities of Dudh Koshi Stakeholders}

Consultations were held with 240 stakeholder groups in the three districts (80 in each district). The respondents were asked to describe and rank their development priorities from 1 to 5 (with 5 as the highest priority). The questionnaire focused on six village development committees closest to the proposed hydropower project in the three districts. The responses provide some preliminary and indicative pointers to the development needs. Table 3 gives a summary of these responses.

\section{Table 3: Stakeholders' Ranking of Development Priorities}

\begin{tabular}{ll} 
Rank & \multicolumn{1}{c}{ Description } \\
1 & $\begin{array}{l}\text { Support for agriculture was ranked the highest with } 70 \% \text { of the respondents indicating } 4 \text { and } \\
5 \text {, which is expected as most respondents are involved in agriculture. Provision of irrigation, } \\
\text { nurseries, seeds, fruit trees, training, and fertilizer were considered important. }\end{array}$ \\
$2 \quad \begin{array}{l}\text { Improved electricity was rated priority } 4 \text { and } 5 \text { by } 47 \% \text { of the respondents, who indicated that } \\
\text { increased wattage for houses and } 24 \text {-hour electricity should be provided. Some respondents } \\
\text { requested to be connected to the national grid. }\end{array}$ \\
$\begin{array}{l}\text { Improved education was rated priority } 4 \text { and } 5 \text { by } 37 \% \text { of the respondents, who listed the } \\
\text { availability of secondary education, computer training, better qualified teachers, and improved } \\
\text { internet as priorities. }\end{array}$ \\
$\begin{array}{l}\text { Roads were rated priority } 4 \text { and } 5 \text { by } 29 \% \text { of the respondents who considered as important an } \\
\text { expanded road network with black topped roads to key centers in each district. Improved roads } \\
\text { together with improved electricity were seen as important to support tourism. }\end{array}$ \\
$\begin{array}{l}\text { Improved health facilities and care workers were rated priority } 4 \text { and } 5 \text { by } 24 \% \text { of the } \\
\text { respondents. }\end{array}$ \\
$\begin{array}{l}\text { Water supply was rated priority } 4 \text { and } 5 \text { by } 21 \% \text { of the respondents, including } 24 \text {-hour supply } \\
\text { and individual house connections and sanitation. }\end{array}$ \\
Other $\begin{array}{l}\text { Respondents also listed microenterprises and tourism, access to credit, training, and advisory } \\
\text { support as important. There was also interest in homestays for tourism. }\end{array}$
\end{tabular}

Source: ADB. 2016. Nepal: Operational Research for the Dudh Koshi River System, Final Report. Unpublished. 


\subsection{Catchment and Hazard Management}

Long-term and sustainable catchment management by reducing erosion and risks from natural hazards is a key priority of the government to support the communities and gain financial returns from hydropower.

Estimates of sediment yield used in reservoir design in the Koshi River Basin (KRB) range from 4,200 tons per square kilometers per year (tons $/ \mathrm{km}^{2} /$ year) to 5,700 tons $/ \mathrm{km}^{2} /$ year, based on the sediment rating curves and empirical equations. Using GIS and remote-sensing techniques along with the revised universal soil loss equation, the ICIMOD prepared maps showing soil erosion in the KRB and priority areas for conservation (Uddin et al. 2016).

Figure 11 presents an extract from the ICIMOD maps for the Dudh Koshi sub-basin. The ICIMOD priority conservation area levels 1 and 2 occupy about $18 \%$ of the catchment area and correspond almost entirely with the top two erosion bands, which produce almost $75 \%$ of the ICIMOD-estimated annual sediment erosion. Concentrating watershed conservation measures in these areas will therefore have significant impact on reducing sediment loads. If erosion from these areas could be reduced by $50 \%$, reservoir life and the life of hydromechanical equipment could be extended by almost $40 \%$.

The Koshi River master plan study (KRMPS) estimated the costs of catchment management at about $\$ 1,000$ per hectare at 2016 prices. ${ }^{10}$ For example, the KRMPS estimates the cost of catchment management for the Sun Koshi 3 project to be about 25\% of the investment costs. For the DKSHEP, the catchment area is $4,100 \mathrm{~km}^{2}$; the estimated cost of full watershed protection would be $\$ 400$ million or $40 \%$ of the investment cost (toe option) or $30 \%$ of the tunnel option.

Based on the KRMPS catchment management costs, addressing priority areas 1 and 2 in the Dudh Koshi River System (DKRS) would cost about $\$ 72$ million. The use of remote sensing and GIS needs to be supported by field investigations. Estimates of sediment erosion should be correlated with measured sediment loads in the rivers.

The potential benefits of catchment management include the extended life of storage reservoirs, reduced maintenance and replacement costs of turbines, reduced floods, and improved livelihoods of communities through jobs and income generation. Subsequent studies have proposed combining income generation with catchment management to boost the local economy.

The High Mountain Agribusiness and Livelihood Project (HIMALI) emphasizes the importance of balancing watershed management with improving and creating sustainable livelihoods in the context of climate change. The Ministry of Agriculture has been implementing the project with support from the ICIMOD and ADB. The HIMALI project has developed initiatives to promote climate adaptation methodologies such as catchment management and development of small-scale agribusiness to support rural livelihoods.

10 Based on $\$ 300$ per hectare at 1985 prices with estimated escalation over 30 years. 


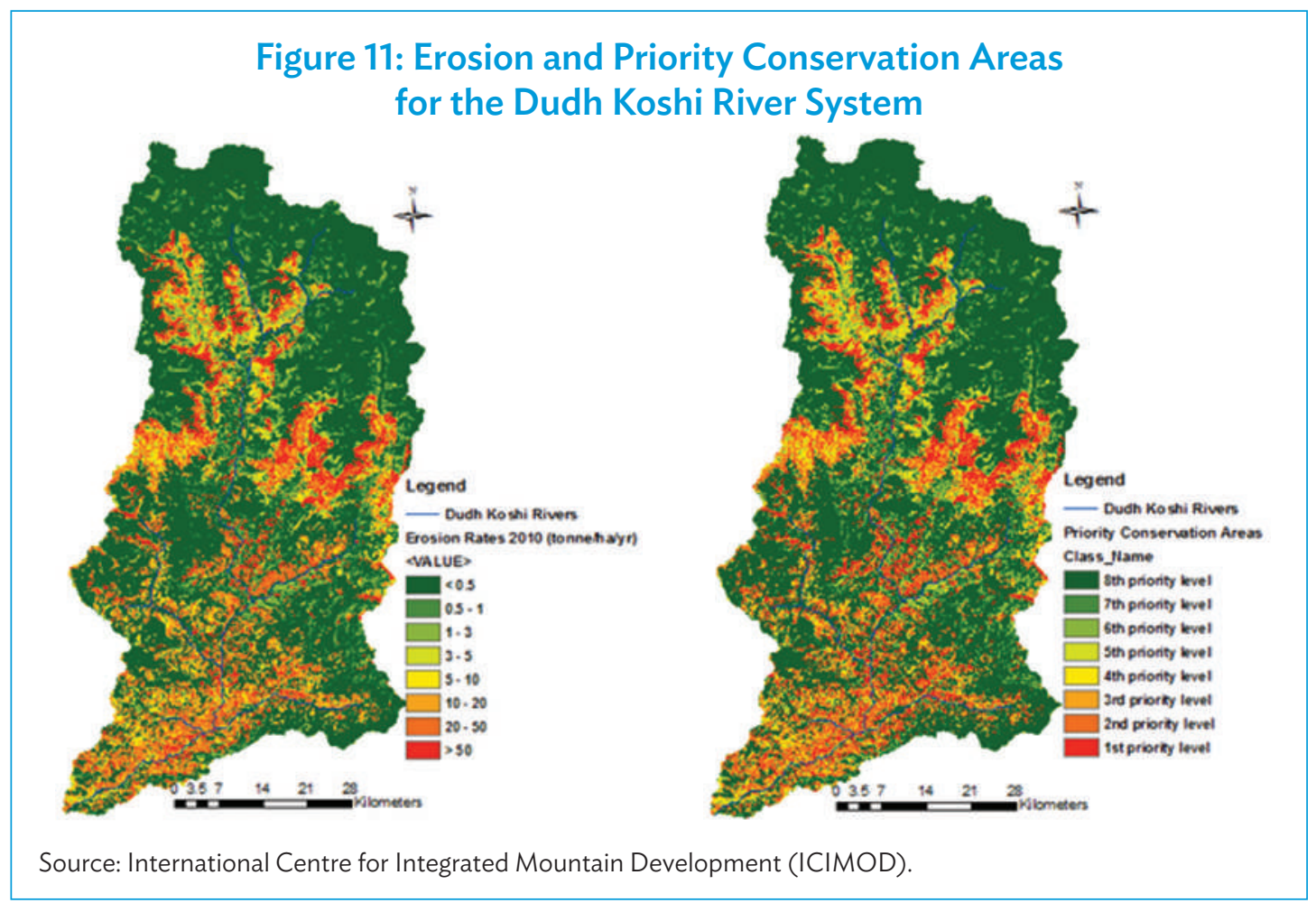

Firewood is becoming an increasing issue both in the cost and in the time to collect it as well as its impacts on the catchments. Firewood in Nepal provides about $80 \%$ of energy consumed, and new initiatives are essential to improve supplies of firewood or reduce its consumption. The high cost of firewood is already resulting in increased use of gas for cooking by higher-income families and businesses. Trials to promote electricity for cooking, such as the development of a low wattage cooker, indicate that only $18 \%$ of the community could afford to pay the power cost (Bell 1994). However, those families who adopt electric cookers have managed to reduce firewood use by about 30\%. Fox (1983) pointed out the importance of improving the management of public lands to increase the availability of firewood especially for low-income groups. The study found that public lands produce about $4 \%$ of firewood for large farmers, but about $48 \%$ for poor farmers. The study revealed that there is no clarity about the legality of firewood collection from public lands, and identified the potential for quick-growing species of fodder and firewood.

Catchment management is critical in reducing erosion and hazards and needs to incorporate the findings and approaches of new research, which can now better assess areas of instability and help pinpoint the core areas of erosion. A better understanding of overland sediment transport is also needed, so that the contributions of specific upland areas to in-stream deliveries (ultimately ending up in reservoirs) can be known.

Management initiatives need to be better coordinated to reduce erosion from all land types, including private and public forest and private agricultural lands. Responses to the buildup of glacier lakes need to be proactive and include reducing levels through physical interventions, such as creating spillways or siphons. Mechanisms and finance to preempt and address landslips and blockages of rivers are critical. 
The scope, objectives, and potential benefits of catchment management need to be defined clearly. The return of investment in catchment management in the form of reduced impacts on hydropower is unclear; drip feeding of investment in the catchments based on a percentage of royalties is very slow with the real benefits not appearing until well into the life of the projects.

The massive costs and uncertain financial and economic benefits for catchment management require more study to develop technically and economically viable initiatives, including targeting key areas of instability or erosion. Investments in catchment management must be initiated early to benefit the hydropower investments.

\subsection{Roads}

Most of the hydropower sites in the KRB have poor road access, while some have none. The DKRS is accessible through the rough, dry weather roads in Okhaldunga and Khotang. The southern part of Solukhumbu can be accessed by road up to Salleri, the district capital. Development of roads and any hydroelectric power project north of the Salleri is very sensitive because of environmental and economic impacts of roads on the pristine area, which has become a tourist attraction largelly based on trekking.

Integration is lacking in planning hydropower schemes and roads. Several roads and bridges in the Sun Koshi and Dudh Koshi basins will be submerged by hydropower reservoirs if some schemes are implemented. Parts of the major new Banepa-Bardibas highway would be submerged if the Sun Koshi 2 project were to be implemented, and the new bridge across the Dudh Koshi if the Sun Koshi 1 project were implemented.

Roads can be a major source of contention in hydroelectric power projects. Planning for roads is dominated by the short-term needs of construction traffic, with developers only prepared to provide the bare minimum of investment. Road conditions in the ongoing relatively small run-of-river hydroelectric power projects in the Solu Khola are poor, and there is no formal agreement between the developer and the local government on the responsibilities for the road investment and maintenance.

Road development requirements need to be properly defined in terms of: (i) adequate provision of all-weather roads with design for heavy construction traffic and with minimal risk of erosion and instability, (ii) routes to optimize benefits to local communities and meet construction needs, (iii) responsibilities for maintenance during construction period, and (iv) costs to be agreed upon and shared between the developer and the government. A part of the benefit-sharing strategy should lean toward roads that have the potential to provide long-term socioeconomic support to both the entire community and the developer. The lack of formal agreements on responsibilities and inadequate finance to upgrade and maintain roads can result in friction during implementation. 


\subsection{Agriculture and Hill Irrigation}

\section{Agriculture}

Most of the cropland in the DKRS consists of terraces carved from hillsides. The hill farms include a mix of crops supported by a few cattle, goats, and poultry. Households use their common lands and forests for livestock grazing and as sources for fuelwood, fodder, and timber. Agriculture in the hills is the primary means of subsistence to meet family needs; and it is constrained by poor financial returns, labor shortage because of migration, and the reluctance of youths to do farm work.

Interviewed stakeholders treat support for agriculture as a high priority. About $25 \%$ of farmers who have secondary businesses are significantly better off than farmers who rely fully on agriculture. Agriculture support needs to be planned in line with other initiatives such as catchment management, reducing demand for firewood, and improving roads to support marketing of produce. Reducing land degradation needs to be balanced with improving agriculture productivity to increase income. Such initiatives must be factored into planning of agriculture support.

\section{Hill Irrigation}

Irrigation is limited to small pockets of land from springs, which due to the geology, are quite limited. Uncertain rainfall because of climate change has affected crop yields. There is some scope to expand irrigation through piped systems, sprinklers, drip, poly-houses and pumping, but the costs are very high and, in general, only a small percentage of communities would benefit. The socioeconomic benefits of irrigation need to be carefully evaluated financially in relation to other initiatives. The difficult terrain and costs of sourcing water do not make irrigation development ideal. Infrastructure investments need to be designed for extremely high levels of irrigation efficiency and initiatives created for high-return cash crops. Investment in irrigation for subsistence crops is unlikely to be economically viable.

\section{Payment for Environmental Services}

In Nepal, payment for environmental services is currently being considered in which upstream communities are paid to manage the catchments better and reduce the impacts, mainly of high levels of sediment, on downstream users. Downstream users would benefit from the decreased levels of silt load, which would extend the life of reservoirs and turbines, and reduce the number of operational closures of intakes because of silt levels. At present, this is being explored; however, the government-enabling policies are not in place, and the level of government support for payment for environmental services is not clear as payments are made to individual landowners rather than to communities. Discussions in Solukhumbu show that much of the erosion has occurred on private land, making it difficult for the government to address through its programs.

Payment for environmental services is a form of benefit sharing that supports the financial viability of marginal hill farmers by prioritizing agriculture initiatives that would increase returns and in turn provide downstream benefit. 
Despite a clear financial benefit to hydropower plants in the form of reduced sediment, the technical and financial benefits of paying upstream users to protect the catchments against depreciating hydropower assets is not clear and needs to be better assessed.

\subsection{Water Supply and Sanitation}

Stakeholders have discussed water supply issues especially during winter, and the impacts of climate change on drinking water such as drying up of water sources, poor recharge to groundwater, and damage to pipes and water infrastructure from higher intensity rainfall (DWSS, DOLIDAR, and MoSTE 2014). Migrant workers coming into the area to work on hydropower construction will increase the local population, putting a strain on water supply and sanitation, and possibly raising the risk of gastrointestinal infections. Improving water supply and sanitation in the communities and labor camps is an important mitigation measure.

Water infiltration into tunnels can have a significant impact on springs. It is not easy to pinpoint the location of and extent of impact to affected springs. Springs within a vicinity ranging $5 \mathrm{~km}-10 \mathrm{~km}$ from proposed tunnels must be inventoried and monitored so that the impacts of tunneling on springs are clearly identified and mitigation measures put in place.

Improved water supply and sanitation should be supported in part by the benefits from the hydropower projects, and specific mitigation measures applied where direct impacts are likely.

\subsection{Fisheries}

River fisheries will be seriously impacted by closures from the hydropower projects as well as modification of the flood regimes in the Terai flood plains following the construction of the Sapta Koshi High Dam. Fisheries programs are required as a mitigation measure, but given good management, communities can benefit from the reservoirs.

It is strongly recommended that fisheries programs are managed on a basin or sub-basin scale and not on a project basis. Properly qualified and experienced personnel need to be engaged for an adequate period of time, and the local communities need to be involved and given adequate training. Sports fishing in reservoirs and rivers is an area with good potential to support the local economy.

\subsection{Rural Electrification and Micro Hydropower}

Stakeholder consultations have identified as a high priority the provision of improved electricity supplies to the local communities-mainly in terms of dependability and some increase in wattage. Stakeholders have also requested that families currently supplied by small hydropower units be connected to the grid. 
Most people receive a limited electricity supply from various small hydropower schemes. Improving electrification of districts will ensure that neighboring communities benefit from hydropower investments. While most of the large schemes will be designed to generate high voltage to supply the national grid, methods that guarantee local communities their supply of improved power have to be established. Developers are often reluctant to provide power to local communities because of the cost of collecting payments and the high cost of distribution.

\subsection{Microenterprises and Tourism}

As seen from stakeholder consultations, most respondents are involved to some degree in small enterprises, which give them higher incomes than they can earn from agriculture alone. Microenterprises can provide income security against the variabilities of agriculture and the impacts of climate change.

Tourism in the DKRS is vulnerable to environmental conditions, and tourists have varying expectations. Questions to be addressed are: (i) how can hydropower be developed to benefit tourism; (ii) in what ways can tourism be promoted in the basin as a means of supporting the local economies; and (iii) how can both tourism and hydropower be developed without destroying the fragile and beautiful environment, which attracts tourists to the area.

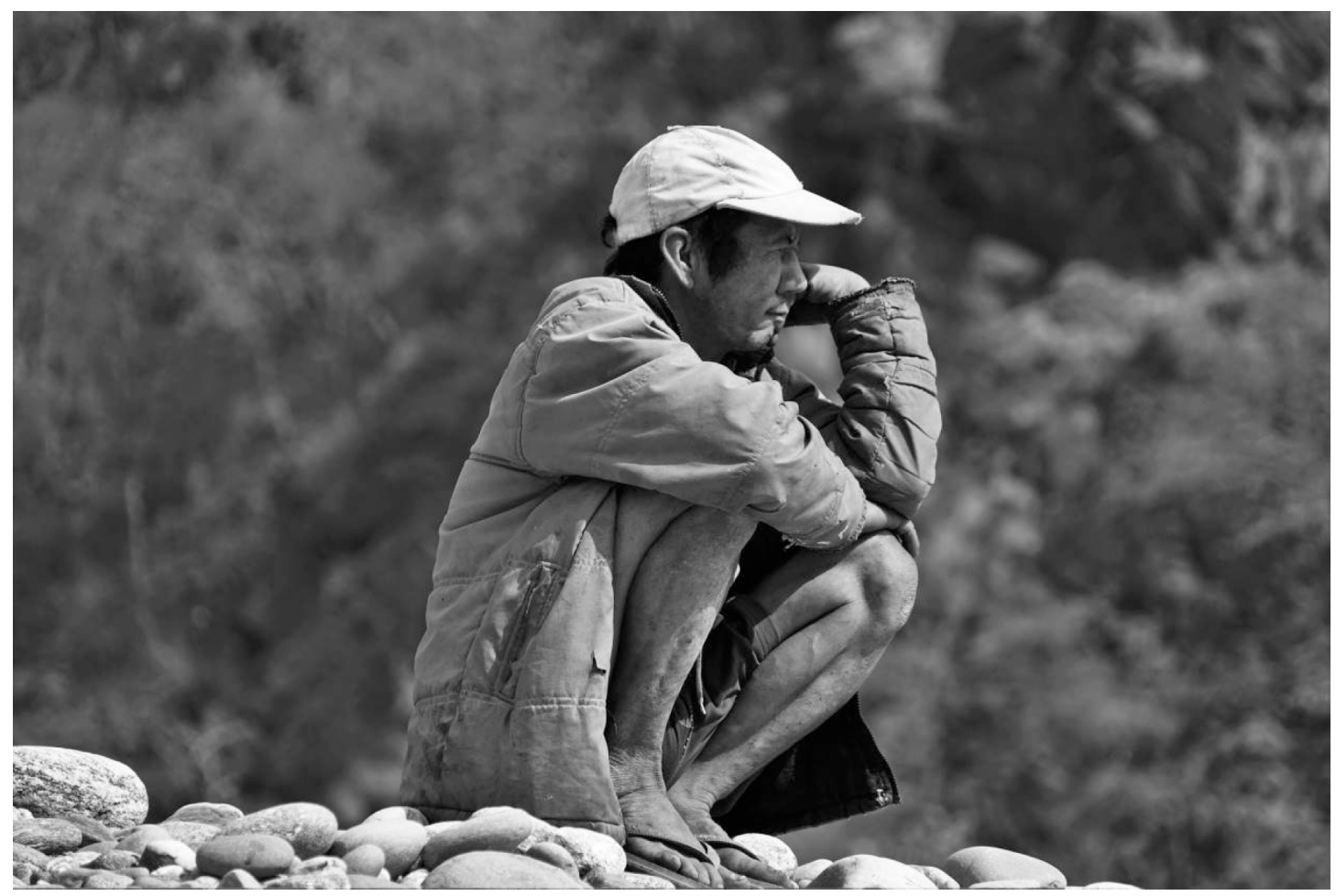

A fisher gazes at the Dudh Koshi River. Hydropower projects will have significant impacts on fish stocks and fishers' livelihoods as fish migration routes are cut off. An integrated basin-wide approach to the development of fisheries management is required to reduce the impacts and develop sustainable mitigation measures. 
Tourism in the DKRS must be planned according to the specific parts of the basin, and planning must carefully consider the sometimes conflicting objectives of increasing tourist numbers and maintaining the fragile environment and the region's socioeconomic condition.

The HIMALI project has developed approaches to support livelihoods in high mountain districts, which could be appropriate. The project has found out that external private enterprises have little interest in supporting agriculture investments, and communities will most likely have to establish their own enterprises. Nepal and India have good experience in community-based farmer enterprises managing small profitable businesses, with stakeholders from local communities as shareholders. 


\section{CHAPTER 7 \\ Legal and Institutional Framework}

\subsection{Requirements}

Although Nepal has the potential to generate 40,000 megawatts (MW) of hydropower, it has produced only around 1,130 MW for over 2 decades, with chronic power cuts of up to 14 hours per day being the norm during the winter season until recently. Uncertainties and lack of clear direction in integrated development planning have delayed most of the proposed schemes for many years, leaving most of them on hold-as is the case of nearly all 1985 Koshi River master plan study proposals for the Koshi River Basin (KRB).

Wide-ranging uncertainties have hindered investment in hydropower such as (i) inadequate policy and legal framework, (ii) the recent constitutional changes, (iii) delays in the formulation of the new electricity act, (iv) water-sharing agreements with India, (iv) low domestic tariffs and poor financial returns, ( $v$ ) environmental and social concerns, and (vi) outdated plans for water resources and hydropower.

A lack of coordination between different sectors is apparent. Despite the development of a comprehensive master plan in 1985, intersector coordination has remained poor. For instance, while there are plans for the diversion of water for irrigation from the KRB to the Terai, there is no clear organization to manage and coordinate irrigation and hydropower water uses. Recently, significant investments in roads and bridges have been made, but these infrastructures will be submerged if some of the hydropower projects are taken up.

\subsection{Legal and Institutional Framework}

The Ministry of Energy Water Resources and Irrigation is the highest office responsible for formulating power sector policy; oversight of planning, investment, and development of the power transmission; and power distribution. The other key water sector in the KRB is irrigation, which is under the same ministry.

The Water and Energy Commission (WEC) was established in 1975 to coordinate water and energy development, and is currently directed by 11 ministries and chaired by the Ministry of Energy. The WEC aims to develop water and energy resources in an integrated and accelerated manner, and is assigned a special role to support the negotiations of transboundary water issues between India and Nepal. The 11 ministries represented in the WEC are supposed to meet regularly but, in practice, meetings have been intermittent. 
The Department of Electricity Development (originally known as the Electricity Development Centre) is responsible for assisting the Ministry of Energy Water Resources and Irrigation in implementing overall government policies relating to the power sector. The major functions of the department are to ensure transparency of the regulatory framework; and accommodate, promote, and facilitate the private sector's participation in the power sector, including licensing of power projects.

The new Constitution of Nepal, which had been pending for many years, was promulgated in September 2015. One of the main elements relevant to integrated water resources management (IWRM) is to have both federal and state governments recognize jointly that water management is a concurrent issue, except for large hydropower and irrigation, which remain as the federal government's responsibilities.

The Koshi Agreement was initiated in 1954 primarily in relation to the Koshi Barrage construction, and was revised in 1966. Development of water resources in the KRB has to consider the 1966 Koshi Agreement, which outlines that India does accept the right of Nepal over the water in the Koshi River; however, the agreement does require Nepal to notify India of the change of use.

\subsection{Planning Frameworks}

\section{Framework for Hydropower}

There is no coordination agency for hydropower development. This seriously affects the progress of investment and exposes it to the risk of inefficiencies and inequalities. The lack of consistent water and energy policies is a major bottleneck, and there is a need to support the formulation of, and agreement on, the new water and energy policy documents - which will open the door for additional credit arrangements by ADB and the World Bank in water and energy.

\section{Framework for Water Resources}

There are severe institutional barriers to IWRM in all water sectors, with the hydropower sector especially remote from the overall objectives of water resources management. IWRM, although prescribed in all the water sector policies, and despite many years of being a flagship program, remains very weak. Although the Water Resources Act (1992) includes hydropower, it is project-oriented and does not define the needs for IWRM. The Electricity Act (1992) is a key document for hydropower but does not refer to compliance requirements with the Water Resources Act.

The Department of Electricity Development issues hydropower licenses, which are usually based on old planning information, and tend to be developer-driven, emphasizing on maximizing power output and financial returns. Hydrological data and analysis are inadequate and deficient, and there is no mechanism to determine project viabilities and assess license applicants on their capacity to implement projects. Licensing must follow the approach of integrated basin management including adequate attention to social and environmental impacts and management. 
The new National Water Resources Policy and the National Water Resources Act will incorporate the new federal structure, define the new requirements, and replace the 1992 water act. Water management responsibilities must be defined clearly and directed toward an integrated approach to river basin planning. The new water resources act would include IWRM principles as well as provide the legal basis for river basin organizations (RBOs).

The new electricity act to replace the 1992 act has been pending since 2007 and it is urgently required to ensure energy security and to provide a stronger base for capital investment.

The close links of water and energy between the KRB and India need to be strengthened. Currently, the focus is on the development of the Sapta Koshi High dam, which is being managed through the Nepal-India Joint Project Office. This enormous project has taken many years to plan and develop, and international and social issues remain complex. Timely decisions are needed on the planned irrigation supplies to the eastern Terai, which have already suffered from delayed decision making for the high dam. Proposals to devolve the decision making of the Kamala Diversion and the Chatara intake have also been made, which would allow them to be taken up as separate projects in advance of the High Dam.

Despite the provisions of the hydropower policy, no effective mechanism exists for community involvement in decision making to ensure local acceptance and ownership. Furthermore, there is also no integrated strategy for the KRB, and projects are considered on a piecemeal basis without much consideration of social requirements and monitoring of licensing compliance. Hydropower projects are at high risk of being politicized by local, regional, and national interest groups, particularly in the ongoing move to federalism. New initiatives to open local investment in hydropower can cause conflicts of interest over financial, social, and environmental requirements.

\section{Ongoing Related Projects}

Ongoing and planned initiatives that relate to the institutions in the KRB include: (i) the Power Sector Reform and Sustainable Hydropower Project to be implemented by the World Bank and the WEC Secretariat in 2016-2020; (ii) the Irrigation Master Plan through Integrated River Basin Planning financed by ADB, which is to be completed by 2019; and (iii) Institutional and Legal Support for Improved Water Management, which is funded by $A D B$ and includes support for the development of the new federal integrated water policy and act and establishment of an RBO in the Bagmati River Basin.

\subsection{The Way Forward}

\section{Strengthening Coordination and Management at the Center}

The Power Sector Reform and Sustainable Hydropower Project proposes to support several initiatives such as (i) river basin planning (including for the KRB) based on the IWRM approach; (ii) the improvement of water resources management and regulation including the new water resources act and capacity building of the WEC Secretariat; (iii) preparation of a hydropower generation master plan; (iv) establishment of a power-trading company; and ( $v$ ) restructuring the Nepal Electricity Authority business to improve management and 
efficiency, including computerized management and installation of smart meters to enhance distribution.

Other key initiatives being supported include the (i) improvement of hydropower licensing to open transparent and competitive systems; and (ii) master planning of rural electrification, which is supported by ADB, with distribution planning supported by the Grid Solar and Energy Efficiency Project.

\section{Development of Devolved Management for the Koshi River Basin}

Long-term sustainable management of the KRB will need to be directed by an organization that is flexible, quick to respond to new challenges, and free to develop institutional and human resource capacities, and has adequate resources. Such an organization must develop a holistic approach to IWRM, should be an RBO based on the KRB's hydrologic unit, and should have a devolved management structure.

The possible roles or mandate of a Koshi RBO would have three parts:

(i) to provide support for holistic water resources and investment planning and related decision making to ensure effective and sustainable management of water resources and the environment;

(ii) to provide support for water regulation, including hydrological, water quality, and environmental flow monitoring; and

(iii) to directly or indirectly support investment and management initiatives such as provision of specialist expertise for fish hatcheries and stocking, catchment and hazard management, irrigation management, and community development initiatives, among others.

Management responsibilities would be multisectoral, focusing on water resources development, such as hydropower, irrigation, water supply, catchments, floods, and fisheries; and should support other rural hydropower development initiatives including benefit sharing. The KRB encompasses 18 districts and 3 provinces. The RBO would be formed to fit sub-basin boundaries and also to work within Nepal's new federal system. The purpose of an RBO depends on the development stage and the specific management needs, and the type of management tasks split between the RBO and other agencies. An RBO can be involved in different tasks including regulation, management and planning, coordination, and implementation. An RBO can have a formal authority assigned to it by the government, and an informal authority through the respect and confidence it receives from decision makers, water users, and stakeholders.

An RBO would incorporate two arms: (i) a river basin council consisting of representatives of government and stakeholders; and (ii) an executive river basin authority (RBA), which would be its implementing arm. Two types of RBAs are possible:

(i) A public RBA, being an integrated part of the government system, has a strong legitimacy, which is important for the RBA that is involved in water allocation, regulation, and enforcement. 


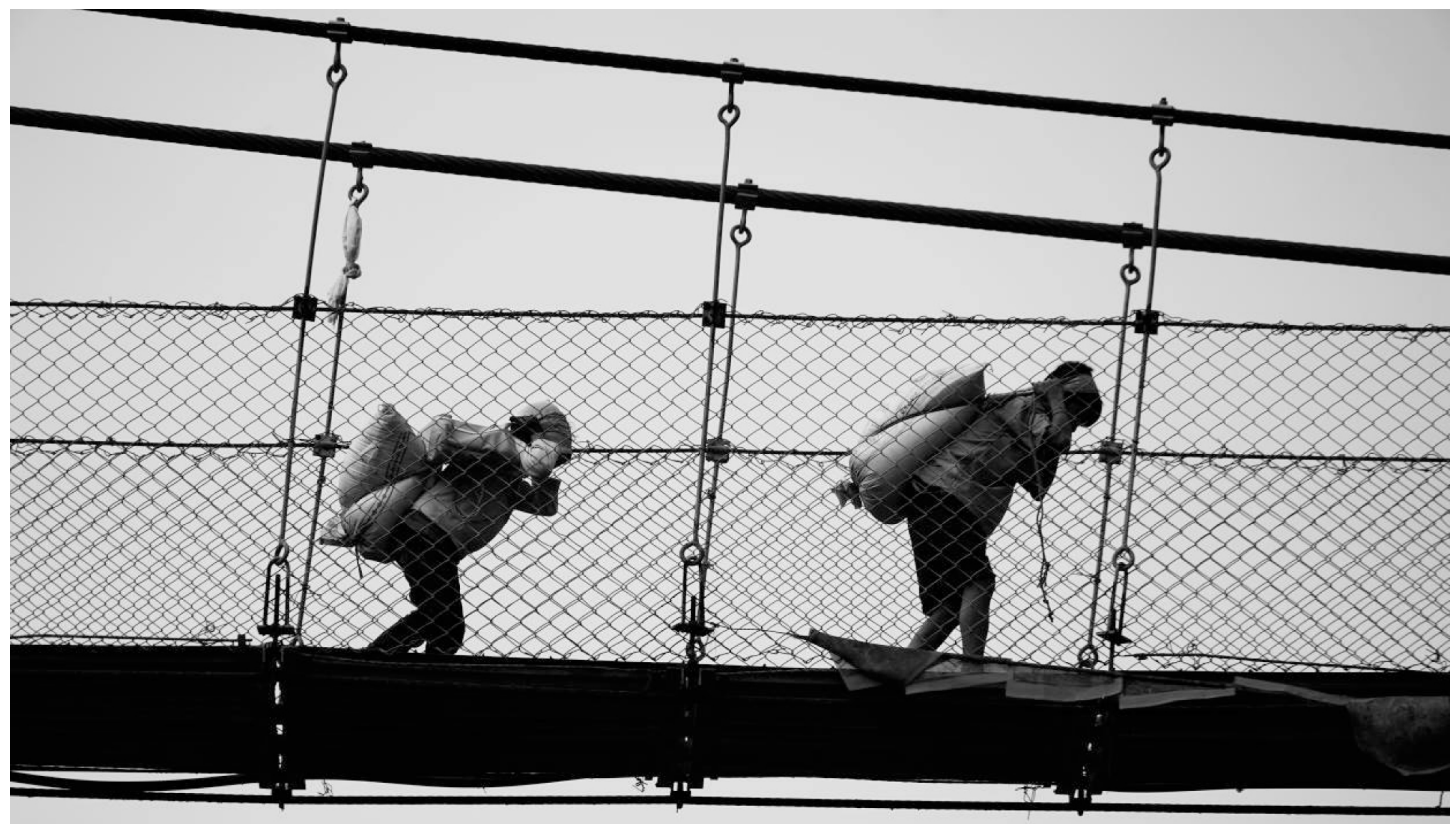

Farmers carry their produce across the Dudh Koshi River. Transportation is a key issue in the Dudh Koshi basin; the whole area lacks good roads and much of the travel and transport remains on foot or by mule. Investment in the basin will open opportunities for increased road access; this however could impact tourism, much of which is based on the attraction of the pristine area away from roads and its unique trekking opportunities.

(ii) A corporate RBA that can derive significant strength from its autonomy and flexibility to implement plans and development initiatives (within its mandate and financial capacity) is able to respond quicker to needs and opportunities. It can also feature a relative strengthening of the basin-level perspective compared with the public RBA (Isnugroho and Nielsen 2014). It can integrate the mandates of different ministries into a holistic approach for the IWRM. A corporate RBA is especially appropriate to situations like the Koshi in which the system of governance for IWRM is weak, technical and management issues are complex, and where there would be adequate financial resources from revenues or royalties to pay for the RBA's management costs. A corporate RBA can be government-owned or private.

Regardless of the type of model, the RBA would report to a high-level government agency consisting of senior government officers and representative stakeholders in the River Basin Council. An RBA under WEC could be a possible option if WEC were to be in a more neutral position than the Ministry of Energy - such as having WEC under the prime minister's office. 


\section{CHAPTER \\ Analysis of Hydropower Development Scenarios}

\subsection{Evaluation of Development Scenarios}

The approach to analyzing development scenarios in the Sun and Dudh Koshi river systems is based on a combination of simulation models of hydrological and water resources systems as outlined in section 2.2 .

The water resources systems modeling is concerned only with storage and diversion projects. Generally, run-of-river (RoR) hydropower development has no impact on downstream water resources, other than in a reach between an RoR intake and its tailrace. In the Sun and Dudh Koshi river systems upstream of Chatara, the storage projects and diversions that need to be considered, in upstream to downstream order, are the:

(i) Sun Koshi 3 Dam,

(ii) Sun Koshi-Marin Diversion (Sun Koshi-Marin Diversion Project),

(iii) Sun Koshi 2 Dam,

(iv) Dudh Koshi Dam (Dudh Koshi Storage Hydroelectric Project [DKSHEP]),

(v) Sun Koshi1 Dam,

(vi) Sun Koshi-Kamala Diversion, and

(vii) Sapta Koshi High Dam.

At present, the most advanced of the above projects are the Sun Koshi-Marin Diversion Project and the DKSHEP, which is currently being proposed with a tunnel diversion and tailrace that is downstream of the Sun Koshi-Kamala Diversion.

WEAP model simulations of project and scenario impacts show hydropower production and river flow characteristics at selected locations. Hydropower is evaluated according to capacity benefit and firm energy production.

(i) Capacity benefit represents the equivalent size of a diesel power plant, which the hydropower plant could replace, and is based on 95\% annual reliability-i.e., the minimum annual 10 -day power output at $95 \%$ exceedance probability. In economic terms, the benefit is calculated as the difference in capital cost of the two types of stations discounted over the life of the hydropower plant (diesel replacement probably at 20 years). In Nepal's context, where development of RoR hydropower is significant, the capacity benefit of storage hydropower projects should be considered with the storage hydropower being used in reserve to take up RoR deficits as the dry season recession develops. 
(ii) Firm energy production is the seasonal reliable energy production. There will be different energy production at different time periods, but firm energy is $95 \%$ reliable and would have a higher value than non-firm energy. Non-firm energy can be deduced from total seasonal production and will have a lower value. Actual energy benefits can be based on value of sales. Dry season runs from November to April, and wet season is from May to October inclusive.

River flow is characterized using flow-duration curves; and river flows at 95\%, 90\%, and $80 \%$ exceedance probabilities at each time throughout the year.

With any hydropower development that involves a flow diversion, a provision is required for an environmental flow in the river downstream of the diversion. The 2001 Hydropower Development Policy (Ministry of Water Resources 2001, p. 8) states that: "Provision shall be made to release such quantum of water which is higher of either at least ten percent of the minimum monthly average discharge of the river/stream or the minimum required quantum as identified in the environmental impact assessment study report."

The hydrological environmental flow criteria take no account of the requirements to maintain aquatic biodiversity in the river system downstream of the diversion. The hydropower policy does require an environmental impact study, which will likely recommend higher flows than the minimum required by the policy. At the level of the Dudh Koshi River System (DKRS) study, resources have not been available to conduct an environmental flow study, and the minimum hydrological requirement was used, as it was in earlier DKSHEP studies and in the Sun Koshi-Marin Diversion Project studies. The use of these flow criteria in the DKRS studies does not imply endorsement of it. The hydrological criteria used internationally are often based on hands-off flows set at $Q_{90}$ or $Q_{95}$. The Scottish Environment Protection Agency has developed a useful guide for the development of RoR hydropower projects (SEPA 2015), much of which would be relevant for Nepal.

The current study has assessed the potential impact of increased environmental flows on RoR hydropower production. The assessment reveals that raising the hydrological compensation flow requirement to $\mathrm{Q}_{90}$ or $\mathrm{Q}_{95}$ would result in a loss of $30 \%-40 \%$ of potential energy production.

\subsection{Scenario Evaluation Results}

A range of combinations of developments is fully discussed in the main report and supporting water resources report (footnotes 1 and 4). Eight scenarios and their impacts on flow duration characteristics at various points in the river system and their reference or index costs are discussed. The reference or index cost for dry season energy is the capital cost divided by the dry season energy production at $95 \%$ reliability and is intended only to permit comparison between different hydropower installations. This should not be confused with a domestic tariff that would be based on discounted costs and an income stream over 40 years.

An example of the impacts of upstream development on flow duration characteristics in the Sapta Koshi downstream of the proposed Sapta Koshi High Dam is shown in Figure 12. The high dam helps to mitigate the impacts of upstream irrigation diversions on low flows in the Sapta Koshi and further downstream in the Ganges. 


\section{Figure 12: Flow Impact of Diversions Upstream of the Sapta Koshi High Dam}

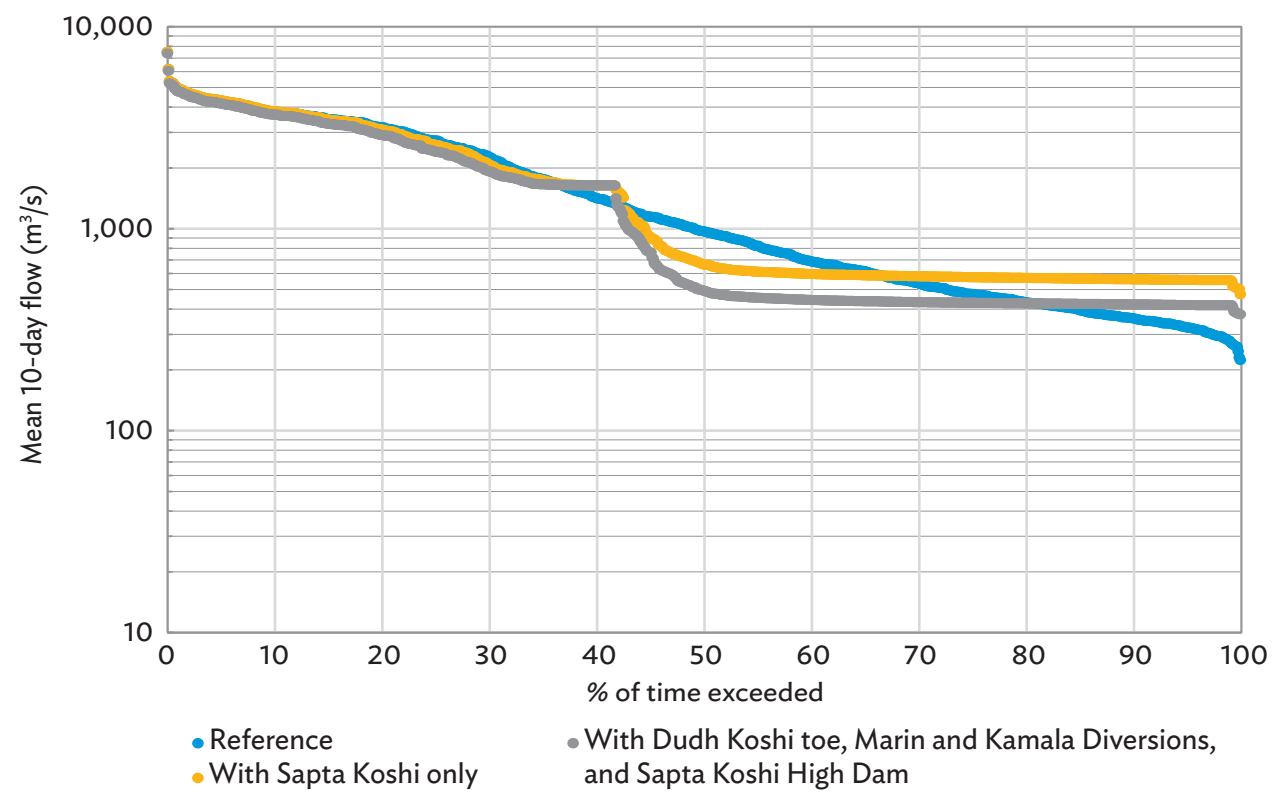

$\mathrm{m}^{3} / \mathrm{s}=$ cubic meter per second.

Source: ADB. 2016. Nepal: Operational Research for the Dudh Koshi River System, Final Report. Unpublished.

Table 4 shows a summary of hydropower production results with full development in the Sun and Dudh Koshi river systems. This scenario was run with the Dudh Koshi toe option as the Dudh Koshi tunnel option diverts away from both the Sun Koshi 1 reservoir and the Kamala diversion. Further details of the impacts of different configurations for the DKSHEP are provided in the main report (footnote 1).

The main conclusions drawn from the analysis are:

(i) The Marin and Kamala diversions, which are high priority projects for the Department of Irrigation, cannot achieve their full potential without provision for storage upstream of either or both diversions. A demand of 72 cubic meters per second $\left(\mathrm{m}^{3} / \mathrm{s}\right)$ in the Kamala diversion cannot be met with $80 \%$ reliability in the dry season; deficits of $20 \mathrm{~m}^{3} / \mathrm{s}$ would occur without storage.

(ii) With storage in the form of the DKSHEP tunnel option, it would be possible to develop either the Kamala Diversion or the Marin Diversion, but not both. For hydropower benefits, the DKSHEP combined with the Kamala Diversion performs better than a combination with the Marin Diversion, and slightly better than the DKSHEP toe option combined with both the Marin and Kamala diversions. Diverting flows through the tunnel will, however, result in significant reductions on flows downstream of the DKSHEP dam during dry seasons.

(iii) With storage in the form of the Sun Koshi 3 dam, the full potential of the Marin diversion can be achieved. The performance of the Kamala diversion is improved and is only marginally poorer than when the DKSHEP toe option is included. 


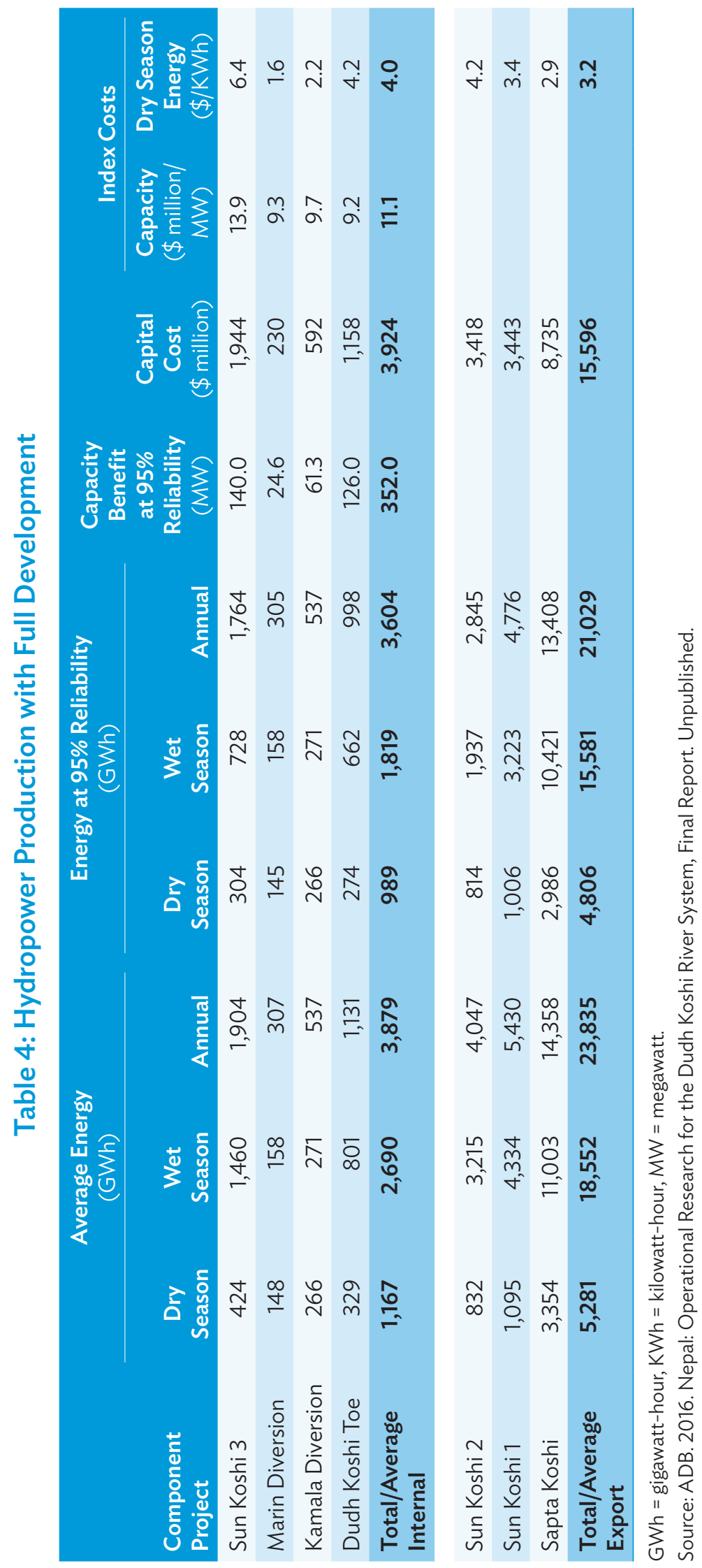


(iv) The cost indexes for the DKSHEP toe and tunnel options are better than those for the Sun Koshi 3 dam.

(v) The Marin and Kamala diversions would have an impact on potential energy production at the Sapta Koshi High Dam — the higher the head, the higher the energy return per unit of water passed through the turbines.

(vi) The Marin and Kamala diversions would, in the absence of the Sapta Koshi High Dam, affect dry season flows downstream of Chatara, and dry season flows in the lower reaches of the Ganges.

(vii) The Sun Koshi 1 dam would not be an attractive proposition without the construction of the Sun Koshi 2 dam. The reliable dry season energy production from the Sun Koshi 1 dam is similar to that of the DKSHEP tunnel option, but at a significantly higher cost.

(viii) The Sun Koshi 2 dam would have significant resettlement needs, and would inundate parts of the recently constructed highway on the south side of the Sun Koshi River.

(ix) Indicative mid-March flow balances for different development scenarios are shown in Figure 13 for the mean flows, and in Figure 14 for drought flows. Caution is required in interpreting these figures as they each relate to the flow condition upstream of the Kamala diversion. The flows are extracted at each location for the year in which the mean or 1-in-5-year drought under the predevelopment condition occurred upstream of the Kamala diversion.

(x) For the mean mid-march flow balance (Figure 13) and with no reservoir storage, the Kamala diversion cannot be met in full and the downstream flow is at compensation level. In the 1-in-5-year drought, the situation is much worse (Figure 14). With the introduction of the DKSHEP toe option, diversion demands are satisfied in full in a 1-in-5-year drought; similarly, with the Sun Koshi 3 dam in place, demands are met.

(xi) Indicative mid-march flow balances for the DKSHEP tunnel option with the Marin Diversion are shown in Figure 15 for the mean mid-March and 1-in-5-year drought mid-March condition. Clearly, either Marin or Kamala could accompany the DKSHEP tunnel option, but not both.

A summary of the energy production results, excluding those already presented in Table 4, is presented in Table 5. 


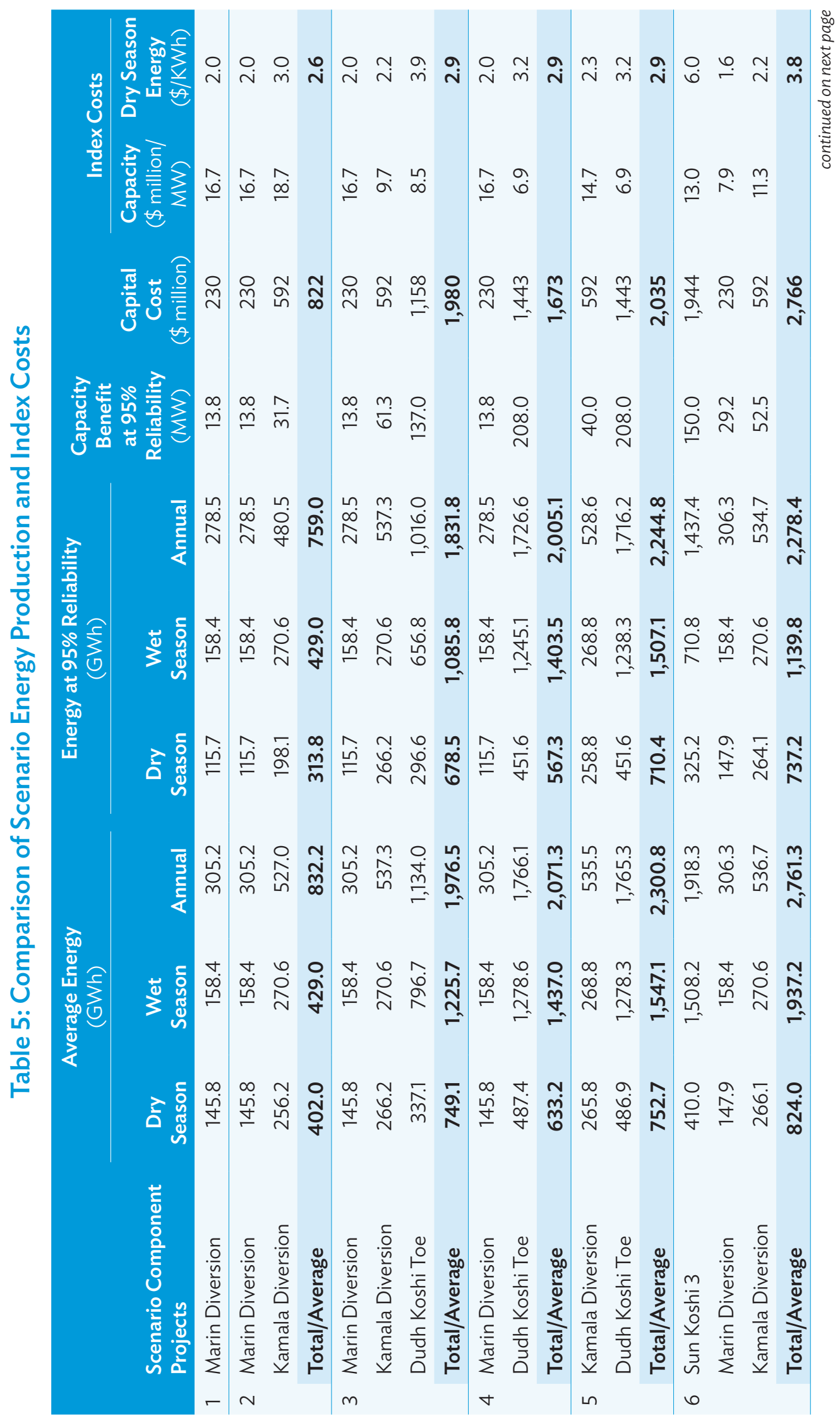




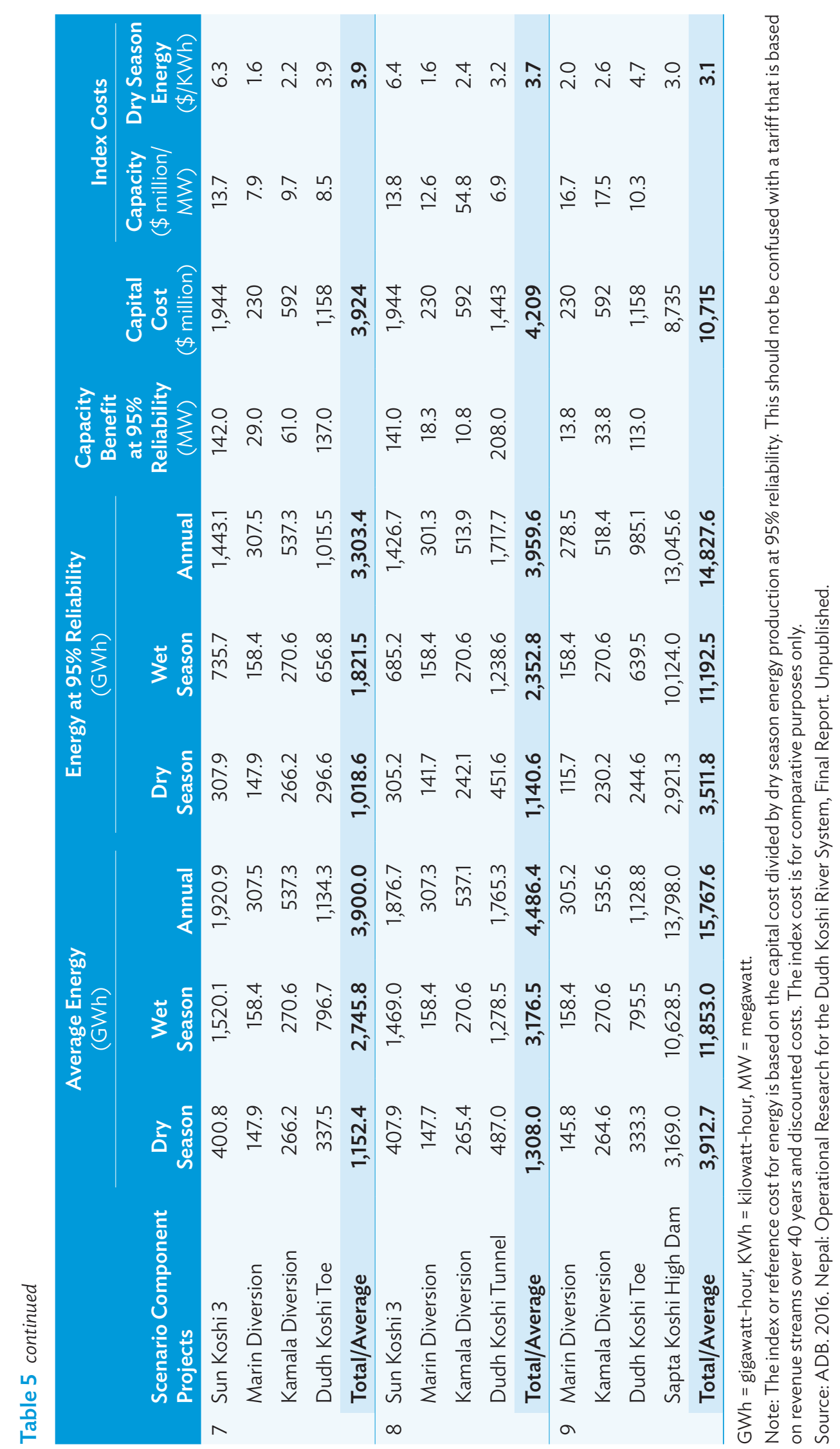


Figure 13: Simulated Mean Mid-March Flow Balances
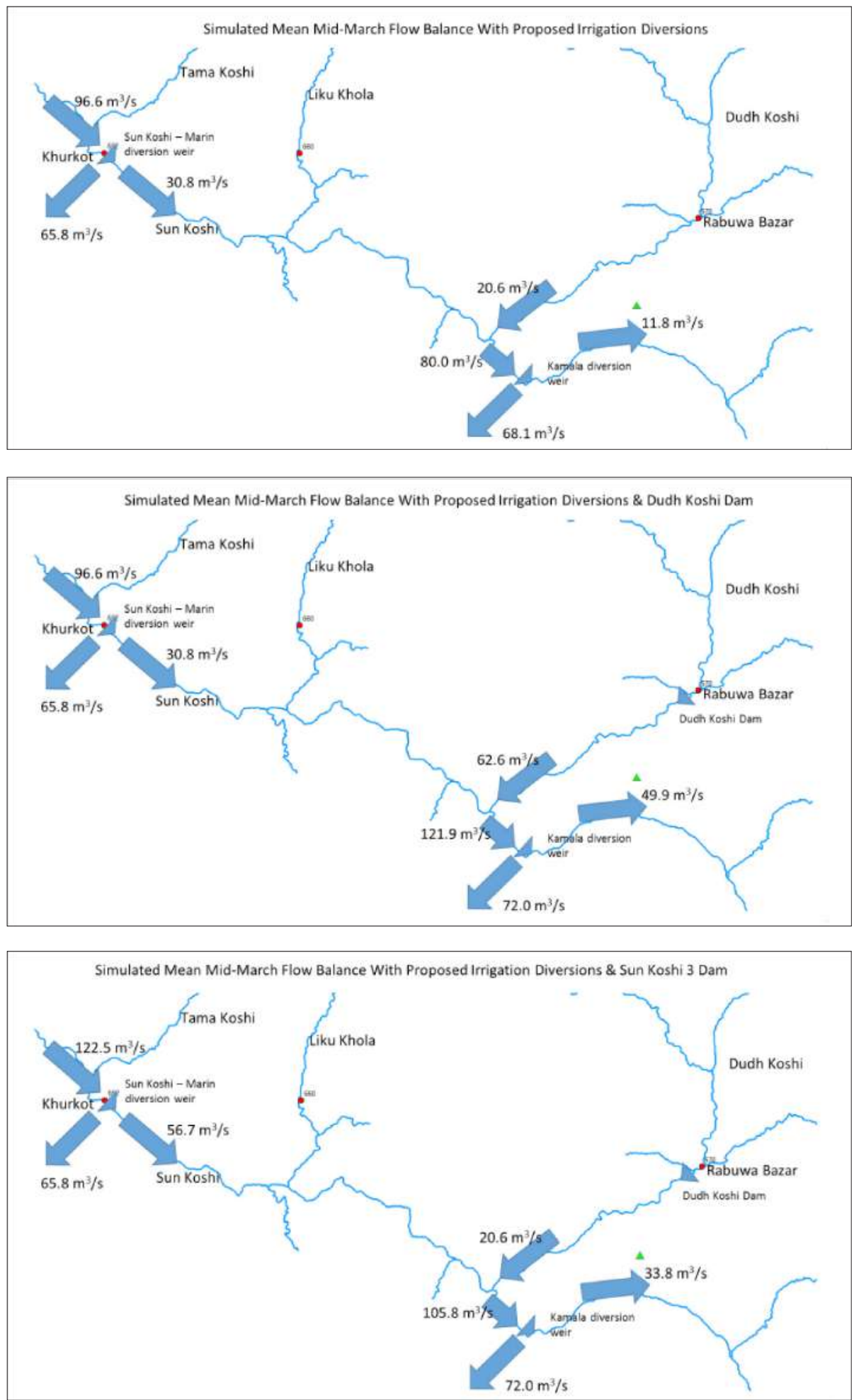

$\mathrm{m}^{3} / \mathrm{s}=$ cubic meter per second.

Source: ADB. 2016. Nepal: Operational Research for the Dudh Koshi River System, Final Report. Unpublished. 
Figure 14: Simulated Mid-March Flow Balances with 1:5 Drought
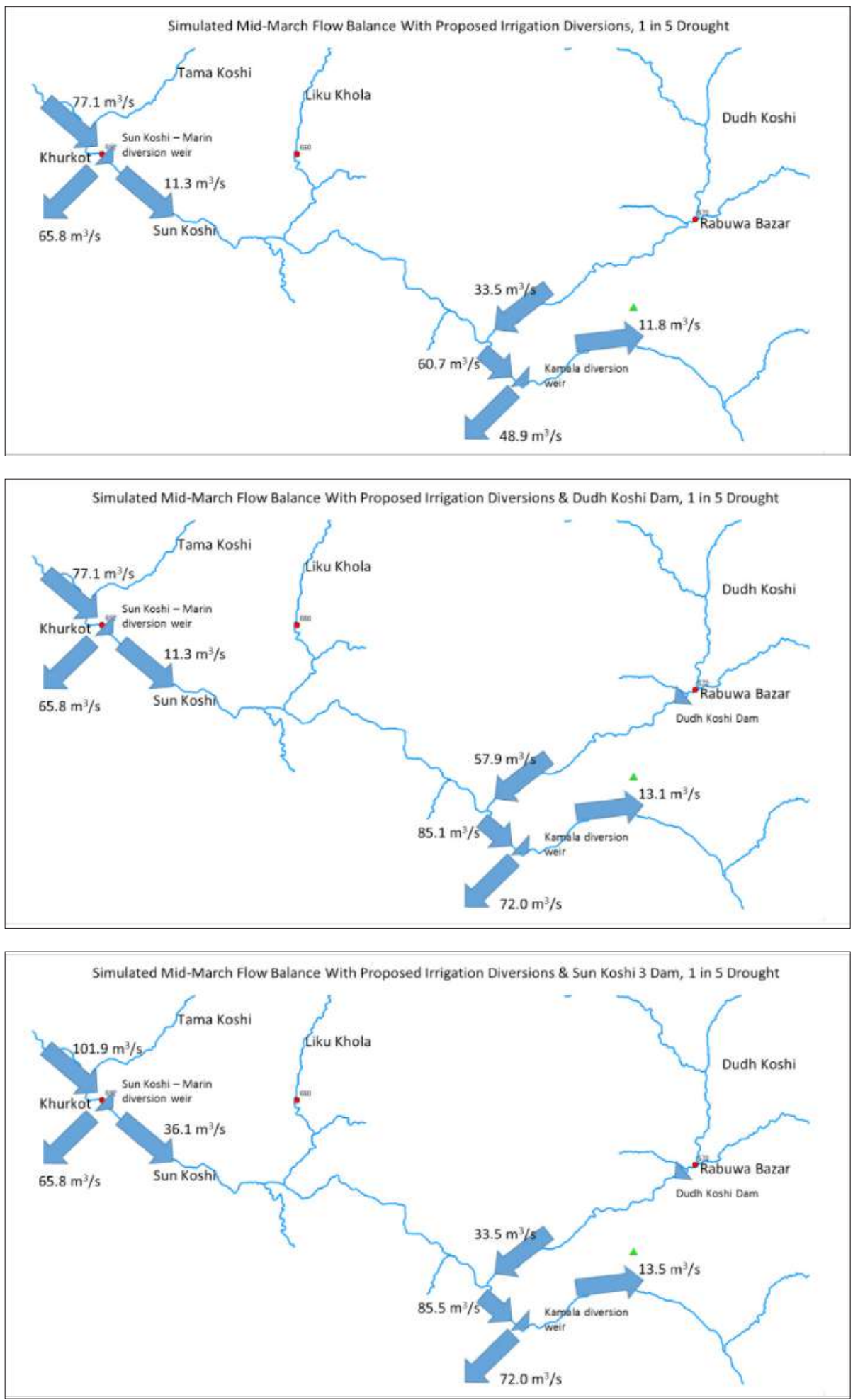

$\mathrm{m}^{3} / \mathrm{s}=$ cubic meter per second.

Source: ADB. 2016. Nepal: Operational Research for the Dudh Koshi River System, Final Report. Unpublished. 


\section{Figure 15: Simulated Flow Balances with the Dudh Koshi Storage Hydroelectric Project Tunnel Option}
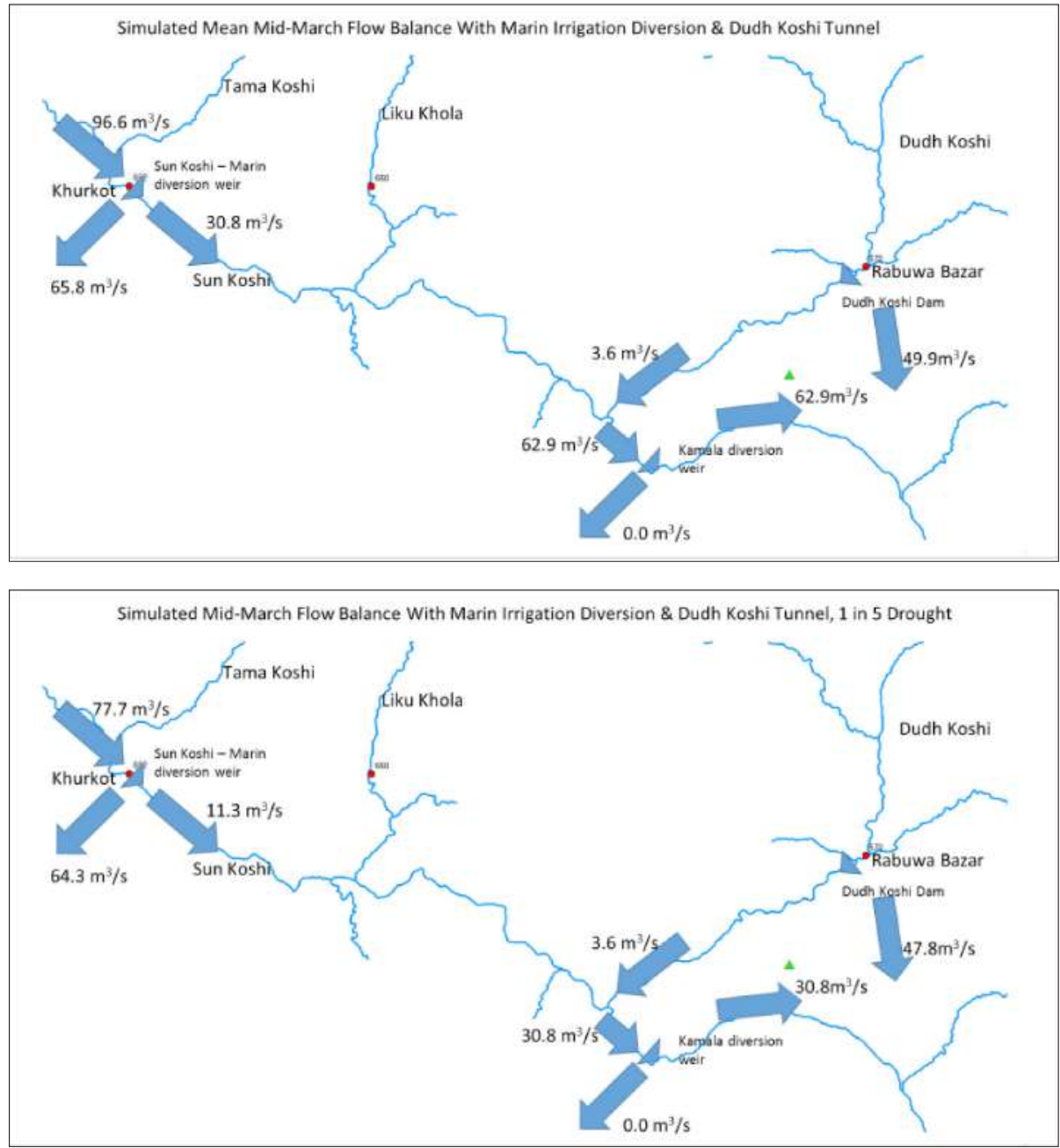

$\mathrm{m}^{3} / \mathrm{s}=$ cubic meter per second.

Source: ADB. 2016. Nepal: Operational Research for the Dudh Koshi River System, Final Report. Unpublished. 


\section{CHAPTERQ \\ Conclusions and Recommendations}

\subsection{Introduction}

The Dudh Koshi River System (DKRS) study reveals that the development of the Dudh Koshi Storage Hydroelectric Project (DKSHEP) cannot be planned in isolation and without integrating its planning and design with other development and environmental requirements. The study's key findings are:

(i) Hydropower planning. The studies and design of the DKSHEP need to incorporate an examination of potential impacts and benefits to other hydropower projects in the Sun Koshi River to assess and decide on the optimum and most viable development option.

(ii) Irrigation diversions from the Koshi River will be affected by the development of the DKSHEP, and the irrigation diversion requirements need to be fully defined in relation to a comprehensive irrigation development strategy and plan including downstream impacts.

(iii) Fisheries and aquatic environment management. The development of hydropower in the Dudh Koshi rivers will have major effects on fish and the aquatic environment. The fisheries and aquatic management measures need to be assessed and implemented based on the wider Koshi River system and not just the Dudh Koshi. New approaches to environmental flows are required to better take into account biodiversity.

(iv) Integrated basin investment. Hydropower projects should be integrated with parallel programs to support sustainable socioeconomic development in the communities and management of the catchments and environment.

\subsection{Hydropower Planning in the Sun and Dudh Koshi River Systems}

Hydropower planning in the Sun and Dudh Koshi rivers needs to consider the following:

(i) The Marin and Kamala diversions cannot achieve their full potential without the provision of storage upstream of either or both diversions.

(ii) The Marin and Kamala diversions-without storage and flow regulation-would have a significant impact on dry season flows in the Sapta Koshi and downstream in the Ganges, where the low flow situation is already considered to be critical. 
(iii) The DKSHEP toe option is implementable and would not have a negative impact on any other project. The releases from storage from the Dudh Koshi toe option would pave the way for the development of both diversion projects (Marin and Kamala), which would provide opportunities for additional hydropower and irrigation benefits. The power and energy production from the toe option are lower than the tunnel option, which will affect the financial and economic returns. The DKSHEP regulation is not sufficient to mitigate the impacts of irrigation diversions in the Sapta Koshi downstream of Chatara.

(iv) The Dudh Koshi tunnel option does provide potential for higher energy production and capacity benefit. However, it cannot be developed without considering other projects. The decision to proceed with the Dudh Koshi tunnel requires a firm commitment to either build the Sun Koshi 3 project, or drop the implementation of one of the two diversion projects (Marin or Kamala). Even with regulation from Sun Koshi 3 and DKSHEP storage, only one of the two irrigation diversions would be possible if adverse impacts on dry season flows downstream of Chatara are to be avoided.

This analysis is based on environmental flows of $10 \%$ of the average mean monthly flows in the driest month as described in the hydropower policy. These values are very low compared with the norms of international best practices (typically $90 \%$ or $95 \%$ exceedance flows when hydrological criteria are used), and do not take into account aquatic biodiversity. The application of higher levels of environmental flows would result in some impacts on the different scenarios, but most significantly on the DKSHEP tunnel option, which would require prolonged compensation releases.

The most critical scenarios relate to the development of four hydropower projects: the DKSHEP (toe and tunnel options), Marin, Kamala, and the Sun Koshi 3. The key operational parameters of these projects and the development scenarios are discussed here.

Major water resources development in the Koshi River Basin (KRB) has not progressed for many years and, clearly, there is a need to move forward with viable and implementable projects and to define a firm sequencing of the projects. The development strategy must be considered in regard to the technical and economic viability of projects, in addition to their implementability within a reasonable period. Some of the key parameters relating to the implementation include:

(i) The DKSHEP and the Marin Diversion projects are in an advanced planning stage. The projects have good performance profiles and low levels of resettlement impact.

(ii) The Marin and Kamala diversions-without storage and flow regulation-would have a significant impact on dry season flows in the Sapta Koshi and downstream in the Ganges, where the low flow situation is already considered to be critical

(iii) The Kamala diversion is currently linked to the planning of the Sapta Koshi high dam; however, there are ongoing proposals to detach the Kamala project, which has good performance profile.

(iv) The Sun Koshi 2 and 3 dams are complicated by the significant requirements for resettlement (for about 4,066 families). The Sun Koshi 2 would inundate major roads. 
(v) The Marin and Kamala diversion projects involve interbasin transfers, which could require necessary technical and environmental clearances including those from the Government of India that could potentially cause delays.

(vi) The Marin and Kamala diversion projects would appear to be viable as stand-alone hydropower projects but, without regulating storage, would impact on dry season flows downstream in the Sapta Koshi.

(vii) The irrigation development on the Terai is complex and will require significant land acquisition and strengthening of irrigation management. A phased approach of the irrigation diversions could be considered.

\subsection{Planning for Irrigation Diversions from the Koshi River}

Three major diversions of water from the Koshi River are being planned to support irrigation in nine districts in the eastern Terai. The planned diversion points are the Sun Koshi Marin diversion, the Kamala diversion, and the Sapta Koshi diversions. The plan is for conjunctive surface and groundwater use to reduce the surface water diversion requirements. The diversion requirements for Kamala can be reduced further by constructing the Kamala storage reservoir. Preliminary estimates of the irrigation requirements have been estimated for the three planned Koshi diversion projects (Marin, Kamala, and Chatara), incorporating the assessment of potential irrigation areas, existing irrigation supplies, and the future irrigation requirements such as a mix of surface and groundwater use. The estimated areas and surface water irrigation demands are summarized in Table 6.

\section{Table 6: Irrigation Diversions}

\begin{tabular}{lcccc} 
& \multicolumn{3}{c}{ Net Command Area (ha) } & $\begin{array}{c}\text { Surface Water } \\
\text { Diversion } \\
\text { Dajor Schemes }\end{array}$ \\
\cline { 2 - 4 } & Other Irrigation & Total & 72 \\
1. Sun Koshi Marin & 87,500 & 34,500 & 122,000 & 95 \\
2. Kamala Direct & 51,000 & 100,000 & 151,000 & 70 \\
$\begin{array}{l}\text { 3. Kamala with Kamala } \\
\quad \text { Reservoir }\end{array}$ & 51,000 & 100,000 & 151,000 & 259 \\
4. Sapta Koshi & 125,000 & 284,000 & 409,000 & \\
Total & $\mathbf{2 6 3 , 5 0 0}$ & $\mathbf{4 1 8 , 5 0 0}$ & $\mathbf{6 8 2 , 0 0 0}$ & \\
\hline
\end{tabular}

ha $=$ hectare, $\mathrm{m}^{3} / \mathrm{sec}=$ cubic meter per second.

a Based on $30 \%$ of irrigation demand met by groundwater.

Source: ADB. 2016. Nepal: Operational Research for the Dudh Koshi River System, Final Report. Unpublished. 
The development of the irrigation diversions is linked to hydropower planning. The irrigation development is complex and involves physical investments, irrigation management, integrated groundwater and surface water use, and intensive support for agriculture. An appropriately staged program will be required, including phasing of the diversion projects.

There are significant problems with the management of surface water irrigation, which has very low efficiencies. The financing of operation and maintenance costs is very low with only minimal contribution from farmers. Financial sustainability must be a clear objective and criteria before expansion can be considered.

Balanced surface and groundwater irrigation, if properly managed, can be sustainable and very efficient. Surface water irrigation can support recharge, and groundwater irrigation can help avoid issues of waterlogging. The irrigation water requirements of the DKRS study are based on a 70:30 surface water to groundwater ratio, which is about the current level. There is scope to increase the use of groundwater, which needs to be studied.

Electrification for groundwater pumping can be an effective support mechanism. Electrification using prepaid meters provides access to efficient cost-effective pumping, which can be effective for charging and cost recovery. Subsidized electricity tariffs set at sustainable levels can help farmers reduce the pumping costs.

Agriculture productivity in the eastern Terai is well below the potential. Irrigation modernization needs to incorporate parallel agricultural investments that will facilitate increased crop yields and better financial returns, particularly for a quicker uptake of new agricultural technologies and improved on-farm water management. To achieve long-term sustainability, agriculture support programs must be based on commercially viable activities such as public-private partnership models with seed money for start-up costs and support from the overall investment program. Activities designed to be robustly financially viable would allow the program to grow and be self-financed.

\subsection{Management of Fisheries and Aquatic Environment}

Hydropower development will have major impacts on the quantity and species composition of fish and the aquatic environment in the KRB, such as those resulting from (i) closure of fish migration by high dams, (ii) restrictions on migration from reduced river flows, and (iii) reduced flooding in the lower river. Unsustainable fishing methods and the partial closure of migration at the Koshi Barrage are already causing a decline in fisheries.

Mitigation measures have been studied and proposed as part of the project environmental impact assessments for several hydropower projects. However, only limited data on the real viability of proposed activities - such as fish passes, hatcheries, restocking, fish capture, and release-are available. Ongoing projects indicate that planning and resources are inadequate and the performance of mitigation initiatives is quite low. 
To mitigate the negative impacts of hydropower development in the $K R B$, the proposed approach to the fisheries and aquatic management program involves the following:

(i) Establish fisheries management and mitigation measures based on a complete river system, and not specific to individual projects. Each hydropower project would be required to contribute to a Koshi River fisheries management and mitigation fund depending on the level of the assessed impact.

(ii) Develop hatcheries and fish stocking for high dams with reservoirs, such as the DKSHEP. Plan the fish stocking with strong management and community institutions in place.

(iii) Install fish ladders or fish passes for lower barrages up to about $20 \mathrm{~m}$, including the proposed barrages at Chatara, Kamala, and Marin. Assess the performance of the existing fish pass at the Koshi barrage and upgrade if necessary. Low velocity natural fish passes that emulate the natural river to promote fish movements should be considered.

(iv) Assess environmental flows according to international best practices, and establish monitoring systems to ensure compliance.

(v) Give consideration to keeping some rivers free of hydropower or reducing levels of development to balance the impacts on major fisheries in other rivers. For example, restricting hydropower development in the Sun Koshi to run-of-river schemes that allow some level of fish passage would balance the full blockage of fish passage on the Dudh Koshi.

(vi) Manage fish stocking in reservoirs through a high level of community participation to ensure sustainability and to benefit the most affected families. Cage culture can provide good income and serve as a mitigation measure, but this would require capital, skills, and marketing facilities to be successful. It is essential to stock triploid or sterile fish to avoid self-breeding which could compete with native species and pose a serious threat to biodiversity.

(vii) Set up a skilled and motivated fisheries workforce basin-wide, with strong technical and management teams and a high level of devolvement to the communities. Careful and thorough fisheries management planning will give a better understanding of the existing fisheries ecology to plan appropriate mitigation measures.

(viii) Sequence mitigation measures. In theory, with adequate management and finance, the current levels of fish production can be maintained with hydro dams and reservoirs by developing hatcheries and stocking reservoirs. Even though fish biomass can be maintained, species composition will change. Most of the indigenous fish species are more difficult to breed and have less productive growth potential than some non-indigenous species. The benefits of reservoir fisheries need to be ring fenced and special initiatives set up to ensure that the river fishermen are prioritized and support for the reservoir fisheries and culture activities is provided.

Fisheries mitigation activities for the Dudh Koshi that are proposed to be part of a basinwide program include (i) conducting a basin-wide study of fisheries and environmental management requirements; (ii) planning and developing mitigation measures for the impacts on fisheries in the Dudh Koshi; (iii) initiating a fisheries and aquatic environment 
management program for the entire Koshi Basin; and (iv) ensuring that the findings of the fisheries and aquatic management studies are incorporated in future plans, such as the proposed Koshi master plan. The lessons learned from the fisheries and aquatic management approach for the DKSHEP should be applied in other rivers and in future schemes. Financing for these activities should be covered by the DKSHEP investment with supporting financing arrangements set up for a wider basin fisheries study and program.

\subsection{Integrated Approach for the Dudh Koshi}

Hydropower development in the Dudh Koshi should be based on an integrated basin investment program (IBIP). The program should consist of investment in hydropower projects that are in parallel with investments to support sustainable socioeconomic development and environmental enhancement in the basin.

The program would incorporate these nine components:

(i) Hydropower investment in the DKRS is ongoing, planned through private and public operators. Total investment in hydropower at full development is estimated at $\$ 1,400$ million, of which the DKSHEP investment comprises about $80 \%$.

(ii) Catchment management is expensive and needs to be integrated and targeted, focusing on priority areas and looking at sustainable and cost-effective initiatives. Investment in catchment management needs to incorporate both government and private lands. Catchment management should include hazard management such as addressing potential instabilities from glacial lake outburst floods and landslide river closures. It is unlikely that the developer would be able to pay for the full catchment management-related costs; a percentage contribution could be assessed and negotiated to deliver adequate financial benefit from reducing silt levels. Royalties and government contribution would cover the balance of costs. There is no information on the level of reduction in sediment yield, which conservation measures could achieve; but an estimated $50 \%$ reduction in sediment yield from the two highest erosion categories could extend the DKSHEP reservoir life by almost $40 \%$, and presumably the life of equipment of run-of-river schemes susceptible to erosion by the same amount.

(iii) New and improved access roads will be required by hydropower developers. Road requirements need to be assessed and an investment plan prepared to identify clearly the requirements based on normal road and construction traffic. Existing road investment must be supplemented to meet developer and community needs and a negotiated part of the costs assigned as part of the development cost. Improved roads will benefit the developer by reducing transportation costs. The developer would pay for the damage to the roads as part of the hydropower mitigation costs.

(iv) A rural electrification plan should be prepared to upgrade access and reliability of rural electricity. Power sources, financing, and institutional models need to be identified.

(v) Support to improve production of agriculture and small enterprises is proposed, including access to new seeds, marketing, storage and minor irrigation, and credit 
and training for small business; these should follow the High Mountain Agribusiness and Livelihood Improvement Project model focusing on small farm enterprises. Agriculture initiatives should be designed to support the catchment condition and reduce soil degradation and erosion.

(vi) Training and awareness campaigns should be conducted for the districts and communities. Programs may include skills training to support employability and small enterprises and specialist training to support socioeconomic development.

(vii) Community infrastructure such as schools, clinics, community center water supply, and sanitation should be improved.

(viii) Fisheries and aquatic environment management would initially focus on the DKRS but some activities, including studies, would be expanded to cover the whole Koshi Basin. Funds would be provided as part of the hydropower mitigation costs and some costs contributed from royalties. Planning needs to involve communities and ensure that affected fishermen and directly affected persons benefit.

(ix) The hydrometric network should be upgraded. An allocation is provided to upgrade the management of the hydrometric network, which is currently in poor condition.

The IBIP activities need to be economically viable and contribute to the economy of the districts and regions over the long term. The financing proposals for the IBIP are described in the following sections.

\subsection{Institutional Framework}

\section{Constraints of the Current Institutional Framework}

Water resources development in the KRB involves a complex mix of integrated water resources planning and management involving different ministries, departments, and local bodies. The DKRS study has identified clearly the gaps in interagency coordination and decision making. There is currently no integrated planning process in place and preparation of master plans are still at an early stage.

The 2015 Constitution set out the strict distribution of federal, provincial, and local jurisdictions with respect to water management; and the government has been preparing the new water resources and electricity acts. It is critical that these new acts present strategies that are consistent with integrated water resources management (IWRM).

The lack of a clear government structure to ensure effective IWRM is not unique to Nepal. Many countries have established river basin organizations to support the different government ministries and departments and to meet the needs of integrated decision-making.

\section{Framework for Planning}

An empowered committee is needed to support the planning and decision making for the hydropower and irrigation diversions for the Sun and Dudh Koshi river systems. Establishing 
a Koshi-empowered coordination committee is proposed to meet immediate needs and help fill the institutional gap. The committee would be tasked to support the planning of hydropower and irrigation in the KRB, and the seven projects in the Sun and Dudh Koshi river systems. The committee would act as a precursor for the development of a permanent stakeholder organization.

The establishment of a Koshi-empowered coordination committee would require Cabinet approval but could be formed reasonably quickly. It is proposed that the committee be chaired by the Water and Energy Commission Secretariat (WECS), with members from the Ministry of Energy, the Ministry of Irrigation, the Nepal Electricity Authority, the Department of Electricity Development, the Department of Hydrology and Meteorology, and the Department of Irrigation. This committee would need the support of a technical and managerial support team.

\section{Framework for Implementation}

The proposal for the DKRS is to develop an integrated investment program for hydropower and basin development involving multiple sectors. A strong organization will be required to support the planning, design, and implementation of programs. A decentralized Koshi river basin organization consisting of these two arms would be established:

(i) A KRB Council of key stakeholders consisting of representatives from the central government, provincial state government, district administrations, communities, stakeholders, and civil society who will advise and direct river management activities. Since the DKRS occupies three districts and lies in the new Province 1 of the new Federal Constitution, the KRB Council would work very closely with the district and provincial governments.

(ii) A corporate KRB Authority that would be a state-owned company tasked with the integrated management of the KRB. The authority would be composed of a mix of government staff on secondment and specialist personnel from the private sector. Hydropower royalty payments and irrigation service fees will cover the operational costs of the KRB Authority.

WECS will provide the KRB Authority with technical direction and in turn report to the central government. WECS will also guide the KRB Council.

The strengths of the corporate river basin authority (RBA) would be derived from its autonomy and flexibility to implement its own plans and development initiatives (within its mandate and financial capacity). It is then able to respond quicker to needs and opportunities, and can integrate the mandates of different ministries into a holistic approach for IWRM. A corporate RBA is especially appropriate in conditions, such as the Koshi, where governance systems for IWRM are weak, technical and management issues are complex, and financial resources from revenues or royalties are adequate to pay for management costs.

Some activities would be implemented by the RBA directly, other activities by parallel government and community initiatives. The RBA would engage with or access high levels of expertise from the private sector, working with government officers on secondment. 
Its scope and mandate would include support for planning, regulation, and enforcement; specialist implementation; and implementation support. Key RBA activities need to be defined but could include:

(i) support for development planning;

(ii) integrated basin development;

(iii) water allocation planning, such as support to the Department of Electricity Development for licensing applications;

(iv) monitoring and ensuring compliance;

(v) support for coordination between hydroelectric power projects and different agencies and levels of government, including district and community administrations;

(vi) support for dispute resolution and planning;

(vii) support for benefit sharing and integrated basin activities;

(viii) basin-level environmental monitoring;

(ix) leadership and support for fisheries and aquatic management;

(x) support for irrigation diversions and management;

(xi) support for microenterprises and public-private partnership, including hill agriculture, catchment management, and tourism; and

(xii) hazard management, including forecasting of floods, glacial lake outburst floods, and landslips.

An example of a functioning corporate-type RBA is the Brantas River Basin Public Corporation in Indonesia, which was established as a fully corporate state-owned organization in 1990. The corporation manages water resources and public infrastructure based on the principles of cost recovery of water resources management service fees paid by commercial users. It supplies hydropower, water for irrigation, and potable water. The corporation has adopted ISO9001 since 1997, and has gained the governments' trust and stakeholder satisfaction through proactive actions.

Interim arrangements. Establishing a permanent RBA requires the development of a complex institutional, legal, and political framework. Initiating the establishment and development of an interim management organization is proposed. The first focus should be the DKRS, supporting and piloting new initiatives for integrating hydropower and basin development.

Over the short term, the interim management organization would be established through a management contract with a specialist private sector water resources and community management organization; they would be engaged for a fixed term of 5 years to support the social, technical, and environmental initiatives associated with developing hydropower and basin development in the DKRS. A permanent RBA would then take over after 5 years. 


\subsection{Follow-Up Studies}

The development of water resources in the Sun and Dudh Koshi river systems needs further studies to assess the viability of different project scenarios and identify the optimum combination in terms of technical, social, and economic viabilities.

The planning studies would complement the DKSHEP feasibility studies and design. An empowered committee with authority to guide decision making should review the plans. These would include (i) updated planning for the Sun Koshi River hydropower and diversion projects and (ii) planning for irrigation diversions from the Koshi River.

\subsection{Integrated Investment in the Dudh Koshi Sub-Basin}

Investment in the DKRS would be integrated with direct investment in hydropower projects, including the ongoing and planned run-of-river projects and the DKSHEP. These projects would run in parallel with the IBIP, which would support hydropower mitigation activities, environmental enhancement, and socioeconomic development.

IBIP financing would be derived from royalties from hydropower production, funds set aside by hydropower developers for mitigation measures, direct investment by hydropower developers from which financial benefit would be derived (such as roads and catchment management), and routine government development funding.

The estimated royalties for the different hydropower projects in the Dudh Koshi sub-basin (including the run-of-river projects) over 30 years is about $40 \%-50 \%$ of investment costs, with a total value of about $\$ 500$ million to $\$ 600$ million, depending on which option is taken up for the DKSHEP. Royalty allocations to districts is set at $12.5 \%$ but this could increase as many activities would contribute to regional development, and some of these regional allocations could be included.

A significant issue with royalties is the slow buildup of payments. Royalty payments only apply when the scheme becomes operational. Under current arrangements, annual royalty payments for the first 15 years are set at $18 \%$ of revenues, of which communities will receive $12 \%$, (effectively only $2 \%$ of the potential royalties). This delayed payment of royalties affects communities significantly, as they see no benefit for many years. In addition, the viabilities of many programs, such as catchment management, need to be initiated as early as possible for them to be effective and significantly beneficial. This study therefore proposes that a significant portion of royalties is provided upfront for basin-wide development initiatives through a loan to meet the needs of priority investments.

\section{Investment Strategy}

The indicative cost of an investment strategy that integrates hydropower, environmental enhancement, and socioeconomic development for the DKRS is \$1,700 million and would incorporate two components: 
(i) Direct investment in hydropower development, which includes the DKSHEP and 10 run-of-river schemes currently under construction or in the process of licensing. The total cost of hydropower investment is estimated at around $\$ 1,400$ million.

(ii) An IBIP supporting the environmental and socioeconomic development of the DKRS implemented in parallel with hydropower development is estimated to cost about $\$ 288$ million.

The IBIP would include eight components with a preliminary estimate for finance sharing as described below.

(i) Catchment management. This would focus on around 100,000 ha of priority erosion areas and incorporate management of hazards, such as glacial lake outburst floods, flash floods, and river landslides. The catchment management would directly benefit hydropower investments by extending the life of storage reservoirs and turbines, and support long-term environmental enhancement and socioeconomic development of the sub-basin. The program would also help create local jobs.

(ii) Roads and construction mitigation measures. These would incorporate the upgrading of roads to meet developers' needs during construction and long-term needs of communities. Social and environmental impacts of heavy construction traffic on local roads would be mitigated through upgraded roads and adequate road maintenance.

(iii) Rural electrification. All communities in the DKRS would have an upgraded and reliable electricity network with increased wattage. Initiatives would include reducing losses, improving efficiency and cost recovery, and piloting prepaid meter systems. Support for new and mini hydropower will also be provided. Rural electrification would support socioeconomic development and possibly reduce firewood needs.

(iv) Agriculture and small enterprises. Support for agriculture and other small enterprises aims to generate income for communities in the DKRS in a sustainable and financially viable manner.

(v) Training and awareness. Programs will be conducted in line with the hydropower policy of involving communities in planning and managing integrated hydropower and basin development programs. Training in construction skills would benefit hydropower investment.

(vi) Community infrastructure. These would support socioeconomic development and include schools, clinics, water supply, and sanitation. Hydropower investment will put additional load on community infrastructure, water supplies will be affected by climate change, and there may be some impacts from tunneling work.

(vii) Fisheries and aquatic environment management. It would include direct fisheries mitigation (as part of the investment) and support for long-term basin-wide fisheries management initiatives.

(viii) Upgrading the hydrological network. This would involve physical work to improve the gauges, and monitoring and analytical studies to improve knowledge on the hydrological systems and on climate change. The network would benefit hydropower investment and environmental management activities. 


\section{Financing}

The IBIP would be financed as two components:

(i) Costs assigned to the hydropower investment ( $\$ 86.6$ million or about $30 \%$ of IBIP costs) would include (a) investments in the basin that give financial benefit to the developer such as construction of access roads and catchment management ( $\$ 76.8$ million); and (b) direct mitigation measures where the developer would have direct responsibility for mitigation ( $\$ 9.8$ million). Under the current DKSHEP feasibility studies, only about $0.75 \%$ of the DKSHEP investment is allocated to supporting actions; it is proposed that this is increased to about 7.5\% of the direct engineering investment. ${ }^{11}$

(ii) Costs to be financed by royalties and government contribution ( $\$ 202.1$ million or about $70 \%$ of the IBIP costs) would include environmental enhancement (\$68.8 million) and socioeconomic development (\$133.3 million).

The total royalties from hydropower schemes in the DKRS over the first 30 years of operation are estimated to be about $\$ 480$ million. IBIP financing from royalties would require about $42 \%$ of the royalties over the 30 years. Further royalties should be available to the DKRS from downstream hydropower projects when they come onstream.

Programs for environmental enhancement and socioeconomic development should be implemented within 7 years of the start of the DKSHEP and financed through a loan repayable from future royalties and government contribution.

Table 7 shows the details of the integrated investment strategy for the DKRS.

\section{Schedule}

Planning and design of the DKSHEP started in late 2016. Subject to the outcome of the planning and design, work construction is estimated to take 7 years.

Subject to the agreement, the IBIP is proposed to be carried out in parallel with the DKSHEP construction works and within the same 7-year duration. To support the IBIP program, an interim management organization would be recruited through a 5-year management contract prior to the establishment of a permanent River Basin Organization. The proposed schedule is shown in Figure 16.

11 Allocations from the DKSHEP feasibility study to supporting actions are $0.06 \%$ for catchment management, $0.8 \%$ for roads, $0.03 \%$ for training, and $0.07 \%$ for fisheries. 


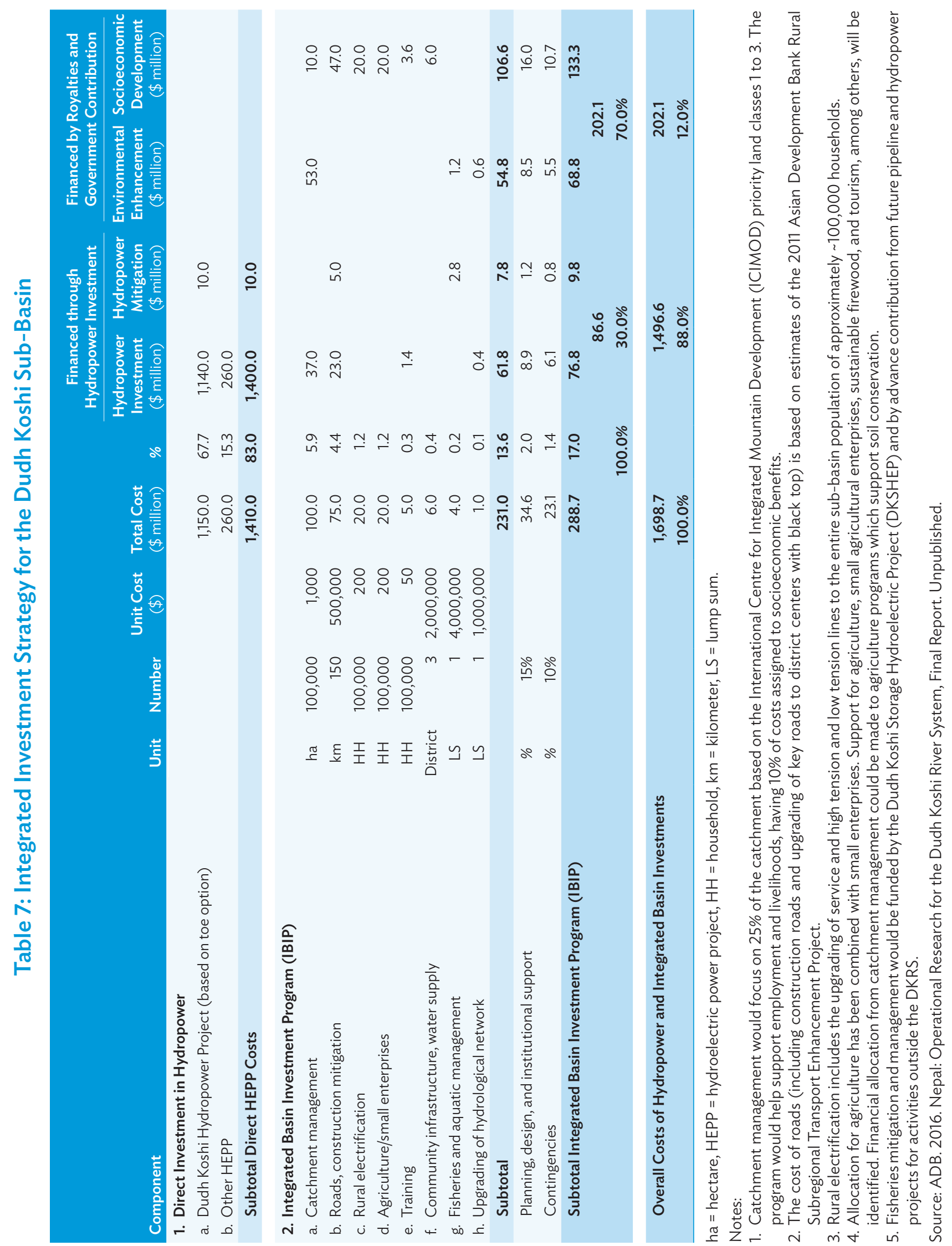




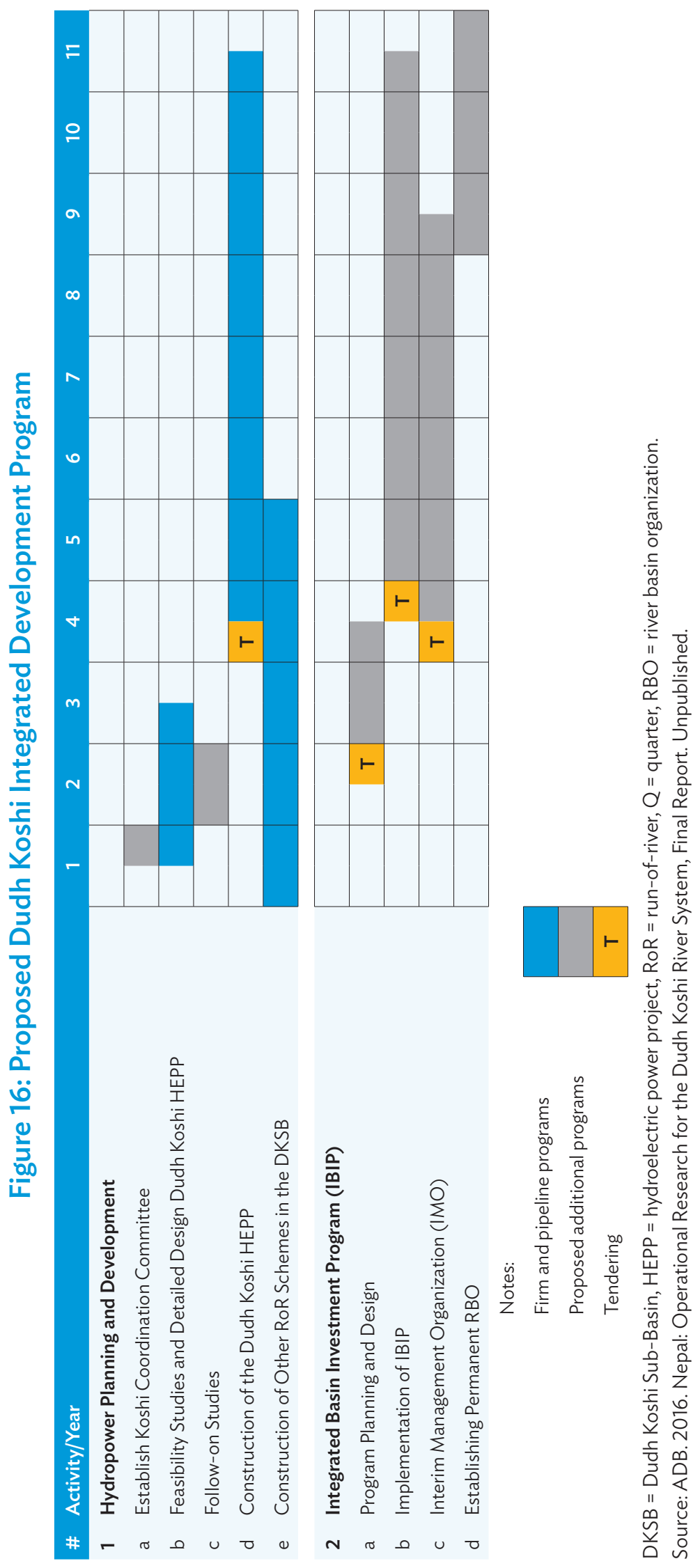




\section{References}

Asian Development Bank. Nepal: Operational Research for the Dudh Koshi River System, Final Report. Unpublished.

- Nepal: Operational Research for the Dudh Koshi River System, Supporting Report on Water Resources. Unpublished.

Bell, J. 1994. Cook Electric: The Ghandruk Experience. Practical Action Nepal. https://answers. practicalaction.org/our-resources/item/cook-electric-the-ghandruk-experience.

Bharati, L. et al. 2015. Water Availability and Agricultural Adaptation Options of the Koshi Basin Under Global Environmental Change: Koshi Basin Final Report. International Water Management Institute (IWMI). Kathmandu: IWMI-Nepal.

Bharati, L. et al. 2014. The Projected Impact of Climate Change on Water Availability and Development in the Koshi Basin, Nepal. Mountain Research and Development. 34. pp. 118-130.

Canadian International Water and Energy Consultants. 1998. Dudh Koshi Hydroelevtric Project: Feasibility Study. Kathmandu: Nepal Electricity Authority.

Chinnasamy, P. et al. 2015. Impact of Planned Water Resources Development on Current and Future Water Demand in the Koshi River Basin, Nepal. Water International. 40 (7). pp. 1004-1020.

Dahri, Z. et al. 2016. An Appraisal of Precipitation Distribution in the High Altitude Catchments of the Indus Basin. Science of the Total Environment. pp. 289-306.

Dixit, M. et al. 2009. Living with Water Stress in the Hills of the Koshi Basin, Nepal. Kathmandu: International Centre for Mountain Development.

Electric Power Development Co., Ltd. (J-Power). 2013. Nationwide Master Plan Study on Storage-Type Hydroelectric Power Development in Nepal. Kathmandu: Japan International Cooperation Agency/Nepal Electric Authority.

Fox, J. 1983. Managing Public Lands in a Subsistence Economy: The Perspective from a Nepali Village. Madison, Wisconsin: University of Wisconsin.

Government of Nepal, Department of Water Supply and Sewerage, Department of Local Infrastructure Development and Agricultural Roads, and Nepal Ministry of Science, Technology and Environment. 2014. Water Supply and Sanitation (WATSAN) Sector Adaptation Plan Framework for Guidelines: Synthesis Report on Adaptation to Climate Change. Kathmandu.

Government of Nepal, Ministry of Water Resources. 2001. Hydropower Development Policy, 2058. 
Isnugroho and T. Nielsen. 2014. Functional Frameworks for River Basin Governance. Indonesia: Research Center for Water Resources, Center for River Basin Organizations and Management, and Network of Asian River Basin Organization. http://www.narbo.jp/ topics/150113_ALL_Functional_Frameworks_for_River_Basin\%20_Governance. pdf?

Japan International Cooperation Agency. 1985. Master Plan Study on the Koshi River Water Resources Development: Final Report. http://open_jicareport.jica. go.jp/617/617/617_116_10313856.html.

Nepal Electric Authority. n. d. A Year in Review: Fiscal Year 2014/2015.

Penton, D. et al. 2016. Preliminary Analysis of Hydroclimate and Streamflow Modelling in the Koshi Basin: Climate, Hydrology, Ecology and Institutional Setting. Commonwealth Scientific and Industrial Research Organization (CSIRO), Sustainable Development Investment Portfolio project. Australia: CSIRO.

Pokhrel, B. et al. 2014. Comparison of Two Snowmelt Modelling Approaches in the Dudh Koshi Basin (Eastern Himalayas, Nepal). Hydrological Sciences Journal. 59 (8). pp. 1507-1518.

Racoviteanu, Y. et al. 2015. Spatial Patterns in Glacier Characteristics and Area Changes from 1962 to 2006 in the Kanchenjunga-Sikkim Area, Eastern Himalayas. The Cryosphere. 9 (2). pp. 505-523.

Savean, M. et al. 2015. Water Budget on the Dudh Koshi River (Nepal): Uncertainties on Precipitation. Journal of Hydrology, Elsevier. 531. pp. 850-862.

Scottish Environment Protection Agency. 2015. Guidance for Developers of Run-of-River Hydropower Schemes.

Securities Board of Nepal. Securities Registration and Issue Regulations, 2008.

Soil Water Assessment Tool. http://swat.tamu.edu/.

Uddin, K. et al. 2016. Estimation of Soil Erosion Dynamics in the Koshi Basin Using GIS and Remote Sensing to Assess Priority Areas for Conservation. PLoS One. 11 (3).

Water and Energy Commission Secretariat. 2011. Water Resources of Nepal in the Context of Climate Change. Kathmandu: Water and Energy Commission Secretariat.

Water Evaluation and Planning. https://www.weap21.org.

Yadav, S. n. d. Survey of Capture Fisheries in the Koshi River Basin. http://www.fao.org/ docrep/005/y3994e/y3994e0z.htm.

Yamada, T. and C. K. Sharma. 1993. Glacier Lakes and Outburst Floods in the Nepal Himalaya. Snow and Glacier Hydrology (Proceedings of the Kathmandu Symposium). 218. Kathmandu: IAHS. 


\section{Managing Nepal's Dudh Koshi River System for a Fair and Sustainable Future}

This publication provides research insights to help develop more equitable and efficient management of water resources in the Dudh Koshi river system in Nepal. It sets out a strategic and holistic planning framework for integrated water resources management and development of the river system. This considers economic and environmental sustainability and the challenges of climate change; technical and social issues; and the potential and combined impacts of multiple projects including hydropower, irrigation, and flood control. The report contributes to basin-wide strategic planning.

\section{About the Asian Development Bank}

ADB is committed to achieving a prosperous, inclusive, resilient, and sustainable Asia and the Pacific, while sustaining its efforts to eradicate extreme poverty. Established in 1966, it is owned by 68 members -49 from the region. Its main instruments for helping its developing member countries are policy dialogue, loans, equity investments, guarantees, grants, and technical assistance. 